\title{
IMPLICAÇÕES DA INTERAÇÃO GẺNÓTIPOS X AMBIENTES NA SELEÇÃO DE PRุOGÊNIES DE SOJA COM ÊNFASE NAS PRODUTIVIDADES DE GRÃOS E ÓLEO
}

JORGE RAMÓN LAÍNEZ-MEJÍA

Tese apresentada à Escola Superior de Agricultura "Luiz de Queiroz" da Universidade de São Paulo, para obtenção do título de Doutor em Agronomia. Área de Concentração: Genética e Melhoramento de Plantas

P I R A C I C A B A

Estado de São Paulo - Brasil

Novembro - 1996 


\title{
IMPLICAÇÕES DA INTERAÇÃO GENÓTIPOS X AMBIENTES NA SELEÇÃO DE PROGÊNIES DE SOJA COM ÊNFASE NAS PRODUTIVIDADES DE GRÃOS E ÓLEO
}

\author{
JORGE RAMÓN LAÍNEZ-MEJÍA \\ Engenheiro Agrônomo
}

Orientador: Prof. Dr. NATAL ANTONIO VELLO

Tese apresentada à Escola Superior de Agricultura "Luiz de Queiroz" da Universidade de São Paulo, para obtenção do título de Doutor em Agronomia. Área de Concentração: Genética e Melhoramento de Plantas

P I R A C I C A B A

Estado de São Paulo - Brasil

Novembro - 1996 


\section{Dados Internacionais de Catalogação na Publicação (CIP) DIVISÃO DE BIBLIOTECA E DOCUMENTAÇÃO - Campus "Luiz de Oueiroz"/USP}

Lainez-Mejía, Jorge Ramón

Implicaçōes da interação genótipos $x$ ambientes na seleção de progênies de soja com ênfase nas produtividades de grãos e óleo / Jorge Ramón Lainez-Mejía. - Piracicaba, 1996.

$145 \mathrm{p}$.

Tese (doutorado) -- Escola Superior de Agricultura Luiz de Queiroz, 1997 Bibliografia.

1. Interação genótipo-ambiente 2. Óleo 3. Parâmetro genético 4. Progênie 5. Soja I. Título 


\section{IMPLICAÇÕES DA INTERAÇÃO GENÓTIPOS X AMBIENTES NA SELEÇÃO DE PROGÊNIES DE SOJA COM ÊNFASE NAS PRODUTIVIDADES DE GRÃOS E ÓLEO}

Aprovada em 07/02/97

Comissão julgadora:

Prof. Dr. Natal Antonio Vello

Prof. Dr. Gerhard Bandel

Prof. Dr. Isaías Olivio Geraldi

Prof. Dr. José Francisco Ferraz de Toledo

Prof. Dr. Daniel Furtado Ferreira
ESALQ/USP

ESALQ/USP

ESALQ/USP

CNPSo/EMBRAPA

UFLA-Lavras

$$
M-1-1.118
$$

Prof. Dr. NATAL ANTONIO VELLO

Orientador 
Dedico especialmente à memória de ROSA AMELIA BORJAS e ADELA PAGOAGA por terem me dado o melhor do mundo:

\section{MEUS PAIS}


Aos meus pais, pelo amor e dedicação

Gersan Laínez Borjas e

Blanca Edith Mejía Pagoaga

DEDICO

Aos meus filhos

Gersan Saady

Jorge Andres (in memoriam)

DEDICO

Aos meus irmãos Hector, Andres, Benjamin, Gersan, Maria, Reina, Rosa, Blanca, Miguel (im memoriam), Carlos e Oscar. 


\section{AGRADECIMENTOS}

A Deus por permitir a finalização destes estudos.

Ao Prof. Dr. Natal Antonio Vello pela orientação, dedicação e amizade durante minha estadia na ESALQ/USP.

Em especial, à Ruth Yimna Blanco Rodriguez, pelo amor, compreensão, estímulo e apoio.

Ao Prof. Dr. Roland Vencovsky e ao Dr. Daniel Furtado Ferreira, pela orientação nas análises estatísticas.

Ao colega João Batista Duarte pela correção deste trabalho.

Aos docentes do Departamento de Genética da ESALQ/USP, pelos ensinamentos recebidos.

À CAPES - Convênio PEC-PG, pela concessão da bolsa de estudos. Ao CNPq, EMBRAPA, FAPESP e FINEP, pelo financiamento de várias etapas do programa de pesquisas que originaram o germoplasma utilizado nesta tese.

Aos funcionários da Seção de Espécies Autógamas do Departamento de Genética da ESALQ/USP: Antonio Roberto Cogo, Claudinei Antonio Didoné, Marcos Custódio Nekatschalow e Osmair José da Silva, pela cooperação nos trabalhos experimentais. 
À Clotilde Maria Batochio Cunha, pela amizade e digitação deste trabalho.

Às funcionárias da Biblioteca do Departamento de Genética da ESALQ/USP: Silvana Marchizolli Gregório e Aparecida Elizabeth Santos da Silva, pela amizade e ajuda durante o curso.

Aos amigos latinos, pela convivência durante estes quatro anos. Aos colegas do Grupo de Soja: Ângela Celis de Almeida Lopes, Gilberto Ken-Iti Yokomizo, Joaquim Adelino de Azevedo Filho, João Tomé de Farias Neto, José Baldin Pinheiro, Juan Carlos Montaño-Velasco, Luiz Fernando Alliprandini, Milton Krieger, Mônica Martins, Osvaldo Toshiyuki Hamawaki, Regina Lúcia Ferreira Gomes, Sérgio Augusto Morais Carbonell, Claudio Yuji Tsutsumi, Fernando Miranda, Sandra Helena Uneda Trevisoli, Maurisrael de Moura Rocha, Diego Soldini e Dario Minoru Hiromoto, pela sua amizade e companheirismo. 
vii

SUMÁRIO

RESUMO................................................................ $\quad x$

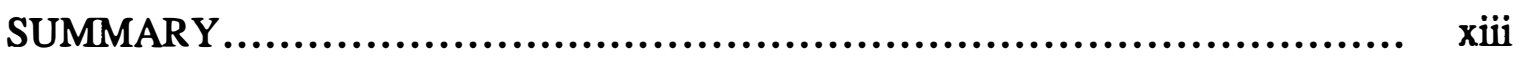

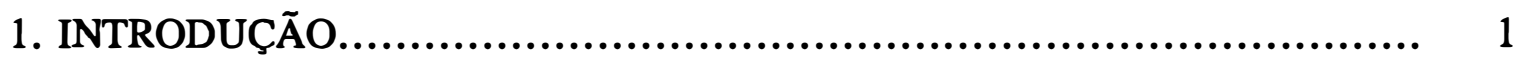

2. REVISÃO DE LITERATURA............................................... 4

2.1. Estimativas de parâmetros genotípicos e fenotípicos em soja............ 9

2.2. Melhoramento para teor de óleo.................................... 15

2.3. Interação genótipos $\mathrm{x}$ ambientes $(\mathrm{G} \times \mathrm{E})$.............................. 19

3. MATERIAL E MÉTODOS.................................................... 26

3.1. Material experimental................................................... 26

3.2. Ambientes de condução dos experimentos............................ 27

3.3. Condução experimental e caracteres avaliados.......................... 28

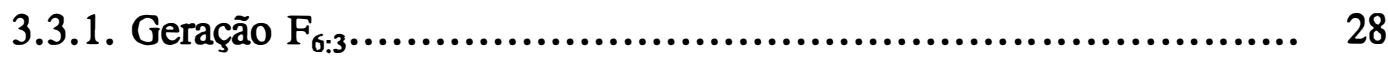

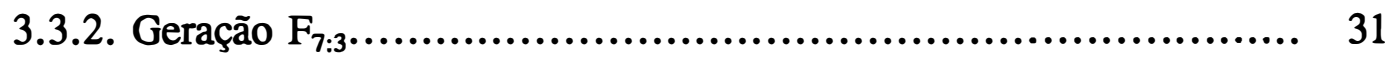

3.4. Análises estatístico-genéticas...................................... 32

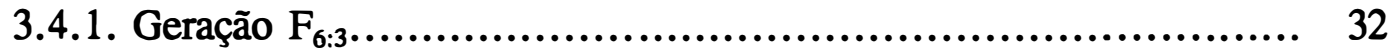

3.4.1.1. Análises individuais de variância........................ 32 
3.4.1.2. Análise conjunta de variância.......................... 37

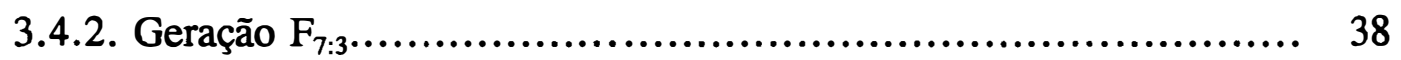

3.4.2.1. Análises individuais de variância....................... 38

3.4.2.2. Análise conjunta de variância........................... 40

3.4.3. Parâmetros genéticos....................................... 40

3.4.3.1. Componentes de variância, herdabilidade, coeficiente de variação genética e índice de variação genética....... 40

3.4.3.2. Ganhos genéticos esperados e observados com a seleção. $\quad 43$

3.4.3.3. Correlações fenotípicas, genotípicas e ambientais........ 48

3.4.4. Análise de variância e parâmetros genéticos reunindo as

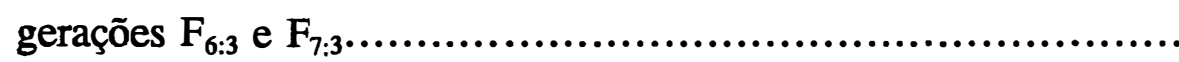

4. RESULTADOS E DISCUSSÃO......................................... 52

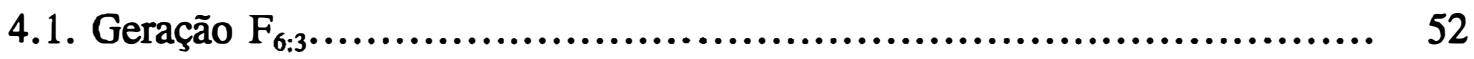

4.1.1. Análises individuais de variância............................... 52

4.1.2. Análise conjunta de variância.................................. 54

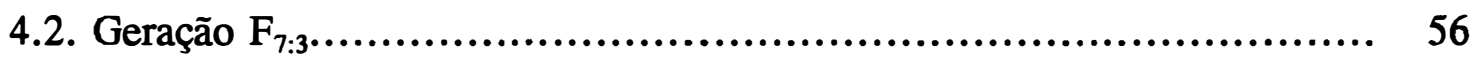

4.2.1. Análises individuais de variância............................... 56

4.2.2. Análise conjunta de variância................................... 59

4.3. Avaliação geral das progênies $F_{6: 3}$ e $F_{7: 3} \ldots \ldots \ldots \ldots \ldots \ldots \ldots \ldots \ldots \ldots . \ldots . \ldots \ldots$ 
4.3.1. Número de dias para a maturidade e altura da planta na maturidade

4.3.2. Valor agronômico e produtividade de grãos....................... 64

4.3.3. Teor e produtividade de óleo.................................... 67

4.4. Componentes de variância e parâmetros genéticos...................... 69

4.5. Magnitude e natureza da interação $G$ x E............................. 74

4.6. Ganhos genéticos com a seleção..................................... 77

4.7. Comparação entre cadeias de cruzamentos.............................. 82

4.8. Correlações entre caracteres............................................. 84

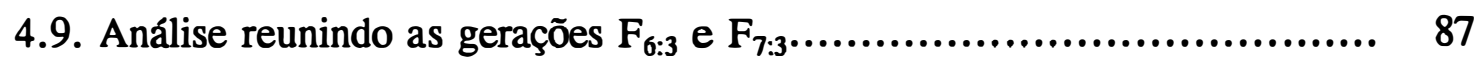

4.9.1. Análise de variância......................................... 87

4.9.2. Componentes de variância e herdabilidade........................ 89

5. CONCLUSÕES..................................................... 92

REFERÊNCIAS BIBLIOGRÁFICAS................................... 95

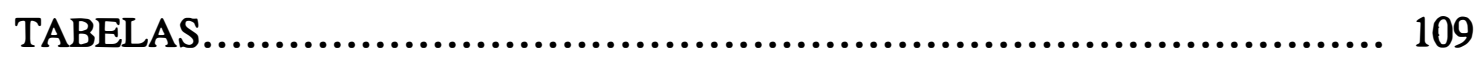

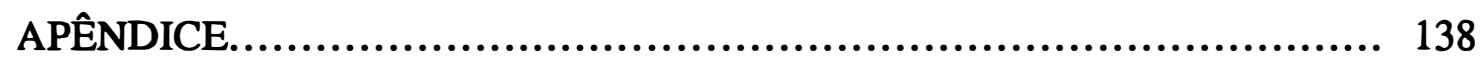




\title{
IMPLICAÇÕES DA INTERAÇÃO GENÓTIPOS X AMBIENTES NA SELEÇÃO DE PROGÊNIES DE SOJA COM ÊNFASE NAS PRODUTIVIDADES DE GRÃOS E ÓLEO
}

\author{
Autor: JORGE RAMÓN LAÍNEZ-MEJÍA \\ Orientador: Prof. Dr. NATAL ANTONIO VELLO
}

\section{RESUMO}

Foram avaliadas progênies $\mathrm{F}_{6: 3}$ e $\mathrm{F}_{7: 3}$ de soja (Glycine max (L.) Merrill) com os objetivos de estimar a interação genótipos $\mathrm{x}$ ambientes $(\mathrm{G} \times \mathrm{E})$ e estudar a sua influência nos parâmetros genéticos e na seleção para produtividade de grãos e óleo. As progênies foram obtidas através de duas cadeias circulantes, envolvendo 40 parentais e 40 cruzamentos biparentais. A cadeia adaptada compreendeu 20 cruzamentos entre parentais adaptados. A cadeia mista foi formada por 20 cruzamentos, cada um deles tendo um parental adaptado e um parental exótico.

Na geração $F_{6: 3}$ foram avaliadas 897 progênies nos locais Areão e Anhembi, no município de Piracicaba-SP. A semeadura ocorreu nas datas de 24 e 25 de Janeiro de 1994, correspondente ao cultivo de outono/inverno (safrinha no Estado de São Paulo). Foi utilizado o delineamento em blocos ao acaso com duas repetições por local. Cada repetição consistiu de 26 conjuntos sendo utilizadas quatro testemunhas comuns ('Bossier', 'IAC-12', 'UFV-4' e 'IAC-Santa Maria-702') em cada conjunto. A análise estatística foi realizada seguindo o delineamento em blocos aumentados para cada repetição. A parcela experimental consistiu de uma fileira de $2,0 \times 0,5 \mathrm{~m}$. Após a avaliação foram selecionadas 210 progênies (120 precoces, 45 intermediárias e 45 tardias). 
A geração $F_{7: 3}$ foi semeada nos mesmos locais nas datas 22 e 28 de outubro de 1994, correspondente ao cultivo de verão (normal no Estado de São Paulo). Para as progênies precoces, foram utilizados dois látices simples $8 \times 8$. Para as progênies intermediárias foi utilizado um látice simples $7 \times 7$, o mesmo ocorrendo para as progênies tardias. Em todos os látices foram feitas duas repetições e incluídas as mesmas quatro testemunhas comuns também utilizadas na geração $\mathrm{F}_{6: 3 \cdot}$. A parcela experimental consistiu de duas fileiras de 5,0 x 0,5 m, deixando-se uma fileira sem semear entre cada parcela. Foram selecionadas 74 progênies (33 precoces, 21 intermediárias e 20 tardias). Os caracteres avaliados, nas duas gerações, foram: número de dias para a maturidade (NDM), altura da planta na maturidade (APM), valor agronômico (VA), produtividade de grãos (PG), porcentagem de óleo nas sementes (\%OL) e produtividade de óleo (PO).

Os resultados mostraram que, apesar da seleção, houve ampla variação genética nas duas gerações para todos os caracteres, excetuando-se o caráter \%OL. Notou-se também que a semeadura da geração $\mathrm{F}_{6: 3}$ na época de outono/inverno permitiu a identificação de genótipos com florescimento tardio em dias curtos (período juvenil longo).

A presença da interação genótipos x locais para os caracteres PG e PO ocorreu nas duas gerações e foi comum para todos os ciclos de maturidade, indicando a existência de um comportamento diferencial das progênies nos dois locais. As estimativas de médias, componentes de variância e parâmetros genéticos mostraram que o local Anhembi foi superior permitindo aos genótipos expressarem melhor o seu potencial genético, principalmente com respeito ao caráter PG. 
Em termos gerais, o componente complexo da interação $\mathrm{G}$ x E no caráter PG, aumentou de 45 a $84 \%$ de uma geração para outra; tal fato, mostra a dificuldade e necessidade de se encontrar genótipos superiores adaptados a uma ampla gama de ambientes, na medida em que se avança o programa de melhoramento.

As progênies tardias, além de serem as mais produtivas, foram as mais afetadas pela interação $G$ x E nas duas gerações, evidenciando a importância da avaliação deste tipo de progênies em mais de um tipo de ambiente. As progênies intermediárias foram as mais estáveis.

O caráter PG esteve correlacionado alta e positivamente com os caracteres APM, VA e PO, indicando a possibilidade de selecionar progênies individuais com valores altos para esses caracteres. Por outro lado, o caráter \%OL apresentou baixas correlações com os outros caracteres; o aumento em PO foi mais influenciado pela seleção para aumentar PG.

A análise reunindo as gerações $\mathrm{F}_{6: 3}$ e $\mathrm{F}_{7: 3}$ mostrou que, as diferenças entre épocas de cultivo (confundidas com efeito de anos) foram mais importantes que as diferenças entre locais.

Os seguintes cruzamentos apresentaram comportamento superior com respeito aos caracteres PG, APM, VA e PO: IAC-9 x GO 79-1030, IAC-6 x UFV-4, Cristalina x IAC-6, BR-9 x EMGOPA-301, EMGOPA-301 x IAC-9, OC 79-7 x BR-9 e AX 5355-5 x Paranagoiana. Somente este último cruzamento pertence à cadeia mista. Os cruzamentos com maior média para o caráter \%OL foram aqueles envolvendo os parentais Planalto-s, BR 80-15725-B-s e GO 81-8491. 


\title{
IMPLICATIONS OF GENOTYPE X ENVIRONMENT INTERACTION ON THE SELECTION OF SOYBEAN PROGENIES WITH EMPHASIS IN SEED AND OIL YIELD
}

\author{
Author: JORGE RAMÓN LAÍNEZ-MEJÍA \\ Adviser: Prof. Dr. NATAL ANTONIO VELLO
}

\section{SUMMARY}

Soybean (Glycine max (L.) Merrill) $\mathrm{F}_{6: 3}$ and $\mathrm{F}_{7: 3}$ progenies were evaluated with the objectives of estimating $G \times E$ interaction and to study its influence on genetic parameters and on the selection for seed and oil yield. The progenies were obtained through two circular chains involving 40 parents and 40 biparental crosses. The adapted chain included 20 (adapted $\mathrm{x}$ adapted) crosses, and the mixed chain originated 20 (adapted $\mathrm{x}$ exotic) crosses.

The $\mathrm{F}_{6: 3}$ generation had 897 progenies evaluated in the localities of Areão and Anhembi, Piracicaba, State of São Paulo, Brazil. The experiments were sown on January 24 and 25, 1994, corresponding to autumn/winter crop (safrinha in State of São Paulo). The randomized complete block experimental design with two replications per locality was utilized. Each replication had 26 blocks with four common checks ('Bossier', 'IAC-12', 'UFV-4' e 'IAC-Santa Maria-702') in each block. For the statistic analysis was utilized the augmented block design for each replication. The experimental 
plot consisted of a $2.0 \times 0.5 \mathrm{~m}$ row. After the evaluation, there were 210 progenies selected (120 early, 45 intermediate and 45 late maturity).

The $F_{7: 3}$ generation was sown at the same localities on October 22 and 28 , 1994, corresponding to summer crop (normal season crop in State of São Paulo). Two $8 \times 8$ simple lattice experimental designs were utilized for early maturity progenies; the intermediate maturity progenies were tested in a $7 \times 7$ simple lattice; another $7 \times 7$ simple lattice design was used with the late maturity progenies. These lattice designs had two replications and the same four common checks included in the previous evaluation. The experimental plot consisted of two $5.0 \times 0.5 \mathrm{~m}$ rows, maintaining an empty row to separate one plot from the other. It was selected $74 \mathrm{~F}_{7: 3}$ progenies, that is: 33 early, 21 intermediate, and 20 late maturity.

The characters evaluated in the two generations were: number of days to maturity (NDM), plant height at maturity (APM), agronomic value (VA), seed yield (PG), seed oil percentage (\%OL) and oil yield (PO).

Results showed that, in spite of selection, there were wide genetic variation in the two generations for all the characters evaluated, except \%OL. The cultivation of $\mathrm{F}_{6: 3}$ generation in the autumn/winter season permitted identification and selection of genotypes with late flowering under short days (long juvenile trait).

The presence of $\mathrm{G} \times \mathrm{E}$ interaction for PG and PO characters in the two generations was common for all the maturity cicles, indicating the existence of different progeny behavior at the two localities.

The adjusted means, variance components and genetic parameters estimates showed that Anhembi was a superior locality, allowing genotypes to better express their genetic potential, specially in relation to PG character. 
In general, the complex component of the $\mathrm{G} \times \mathrm{E}$ interaction for PG character increased from 45 to $84 \%$ between generations, showing the difficulty and necessity to find superior genotypes adapted to a wide range of environments as the breeding program advances.

The late maturity progenies, in addition to be the most produtive ones, were the most affected by the $\mathrm{G} \times \mathrm{E}$ interaction in both generations, indicating the importance of testing this type of progenies at more than one environment. The intermediate maturity progenies were the most stable ones.

The PG character was high and positively correlated to APM, VA and PO characters, indicating the possibility of selecting progenies with combinations of high values for those characters. On the other hand, the \%OL character presented low correlation with other characters. The increase on PO character was more influenced by selection to rise PG character.

The joint analysis of $F_{6: 3}$ and $F_{7: 3}$ generations showed that the difference in cultivation date (confunded with year effect) was higher source of variation than that due to localities.

The crosses with better behavior in relation to PG, APM, VA and PO characters were: IAC-9 x GO79-1030, IAC-6 x UFV-4, Cristalina x IAC-6, BR-9 x EMGOPA-301, EMGOPA-301 $x$ IAC-9, OC79-7 $\times$ BR-9 and AX5355-5 $x$ Paranagoiana. The latter is a mixed chain cross. The crosses with higher averages for character \%OL were those involving Planalto-s, BR80-15725-B-s and G081-8491 parents. 


\section{INTRODUÇÃO}

A importância mundial da soja (Glycine max (L.) Merrill) deve-se à combinação altamente favorável de quatro caracteres: produtividade de grãos $(2 \mathrm{t} / \mathrm{ha} \mathrm{em}$ média), adaptação a ambientes diversos, elevados teores de proteína (40\%) e óleo (20\%) nas sementes. $\mathrm{O}$ Brasil é o $2^{\circ}$ maior produtor mundial de grãos de soja, com cerca de 25 milhões de toneladas por ano e é o $3^{\circ}$ maior produtor de óleo de soja, sendo que na safra 1995/1996 a sua produção estimada foi de 3,74 milhões de toneladas (Roessing, 1995).

Até o presente, com exceção de alguns poucos contratos internacionais (p.ex. importação de grãos pelo Japão), os teores de proteína e óleo não têm sido devidamente valorizados nos programas de melhoramento. A razão principal é a inexistência de premiação comercial para os grãos de soja mais ricos em proteínas e óleo. Cientificamente, é possível aumentar tanto o teor de proteína quanto o teor de óleo nas sementes de soja.

O caráter teor de óleo é determinado principalmente pela ação aditiva dos genes e tem alta herdabilidade, podendo ser aumentado através de seleção fenotípica. No entanto, por ser um caráter de herança quantitativa como a produtividade de grãos, é influenciado tanto por fatores genéticos quanto ambientais. 
Um dos maiores problemas que os melhoristas de plantas enfrentam é a existência da interação genótipos $\mathrm{x}$ ambientes ( $\mathrm{G} \times \mathrm{E})$, razão pela qual os testes preliminares de linhagens nas gerações iniciais de seleção são conduzidos em uma ou duas localidades para se identificar linhagens com ampla adaptação (Van Sanford et al., 1993).

A interação $\mathrm{G}$ x E não só dificulta o processo de seleção como também afeta as estimativas dos parâmetros genéticos, influenciando as inferências feitas sobre uma população, especificamente no que se refere ao ganho genético com a seleção e especialmente quando o material é testado numa dada situação e as recomendações devem ser extrapoladas a outras condições (Allard \& Bradshaw, 1964; Takeda et al., 1991).

A estimação da magnitude e a natureza da interação $\mathrm{G} \times \mathrm{E}$ em caracteres quantitativos numa população sob seleção é importante porque indica ao melhorista o grau de dificuldade para a obtenção de genótipos promissores numa ampla gama de ambientes. Assim, oferece subsídios para definir as estratégias na continuação de um programa de melhoramento que esteja em andamento.

Este estudo é parte do programa de melhoramento genético de soja iniciado em 1983 no Departamento de Genética da Escola Superior de Agricultura "Luiz de Queiroz" da Universidade de São Paulo. O programa visa, por meio de seleção recorrente e utilização de germoplasma exótico, a ampliação da base genética da soja e a obtenção de genótipos com valores altos de produtividade de óleo entre outros caracteres de valor agronômico. Os objetivos específicos deste estudo são: 
- avaliar e selecionar, em duas localidades, as progênies $F_{6: 3}$ e $F_{7: 3}$ de ciclo precoce, intermediário e tardio para vários caracteres agronômicos, com ênfase na produtividade de grãos e óleo;

- estimar a magnitude e natureza da interação G x E;

- estudar o efeito da interação $\mathrm{G}$ x $\mathrm{E}$ nas estimativas dos componentes de variância $\mathrm{e}$ parâmetros genéticos, incluindo-se correlações genotípicas, fenotípicas e ambientais entre pares de caracteres. 


\section{REVISÃO DE LITERATURA}

A soja (Glycine max (L.) Merrill) é uma espécie autógama com $2 \mathrm{n}=$ 40 cromossomos. Segundo Bonetti (1978) a origem da soja é na região leste da Ásia, emergindo como planta cultivada na região nordeste da China no século XI A.C. Foi distribuída para a Europa no século XVIII, à América do Norte no início do século XIX e, finalmente, por volta de 1930 à América do Sul. No Brasil, a soja tornou-se importante na década de 70 , quando a cultura atingiu um crescimento anual de $32 \%$ entre os anos de 1970 e 1977, colocando o país como o segundo produtor mundial de grãos de soja (Bonato \& Dall'Agnoll, 1985).

Vello (1992) afirma que a soja é a espécie em que se conseguiu aproximar mais da maximização da produtividade, através da associação do uso racional e eficiente do ambiente com o melhoramento genético, sendo que este último componente tem contribuído para a agricultura mundial com o desenvolvimento de cultivares de soja com alta produtividade de grãos.

Num estudo sobre os efeitos do melhoramento genético da produtividade de grãos de soja, Luedders (1977) calculou que nos Estados Unidos a produtividade média de grãos foi aumentada de $760 \mathrm{~kg} / \mathrm{ha}$ (1924-1926) para $1863 \mathrm{~kg} / \mathrm{ha}$ (1971-1973), correspondendo a um incremento anual de 5,21\%. Wilcox et al. (1979) calcularam um 
ganho de $25 \%$ em 50 anos no Oeste dos Estados Unidos para cultivares dos grupos de maturação II e III. Para a região Norte dos Estados Unidos, Specht \& Williams (1984), citados por Miranda et al. (1990), mostraram um ganho genético médio de 18,8 kg/ha/ ano.

No Brasil, Toledo et al. (1990) estimaram ganhos médios de $1,5 \%$ por ano de melhoramento de soja no Estado do Paraná, e Miranda et al. (1990) reportaram um acréscimo de 34,9 kg/ha/ano no Estado de São Paulo.

Como acontece na maioria das culturas, os programas de melhoramento genético da soja têm como principal objetivo a produtividade de grãos. No entanto, existem outros caracteres para os quais os programas estão trabalhando: produtividade de óleo, produtividade de proteína, qualidade de óleo e proteína, tolerância à acidez do solo, salinidade e resistência a doenças e pragas.

Segundo Hallauer \& Miranda $F^{\circ}$ (1988), o estudo da variação genética é fundamental para o planejamento e condução de um programa de melhoramento. Além disso, este estudo permite a avaliação da viabilidade da continuação de um programa de melhoramento que esteja em andamento. Na soja têm sido feitos vários estudos da variação genética na maioria dos caracteres de importância econômica. Gates et al. (1960), Brim \& Cockerham (1961), Hanson \& Weber (1962) e Loiselle et al. (1991) encontraram que a variância aditiva é o principal componente da variância genética para a maioria dos caracteres, com pequena participação da variância epistática aditiva $\mathbf{x}$ aditiva; sendo que diversos estudos têm demonstrado a existência do vigor híbrido para produtividade de grãos (Chauhan \& Singh, 1982). 
Um requisito importante para o melhoramento de qualquer cultura é a sua diversidade genética. Os programas de melhoramento genético de soja têm produzido progressos impressionantes nos últimos 50 e 20 anos nos Estados Unidos e Brasil, respectivamente; porém, à expensas da perda de uma grande porção de variabilidade genética originalmente disponível (Vello, 1995). Segundo Hiromoto \& Vello (1986), a base genética da soja cultivada no Brasil é representada por 11 linhagens ancestrais, contribuindo coletivamente com cerca de $90 \%$ e individualmente com 3 a $14 \%$ dos genes do germoplasma cultivado. A base genética estreita, como da soja, leva a dois tipos de problemas: estabelecimento de patamares de produtividade e vulnerabilidade do germoplasma aos estresses ambientais, incluindo-se suscetibilidade a patógenos (Vello, 1995).

A utilização de germoplasma exótico (PI's) pode aumentar a diversidade genética em um programa de melhoramento (Pfeiffer et al., 1991). Schoener \& Fehr (1979) e Vello et al. (1984) compararam populações de soja com 0, 25, 50, 75 e 100\% de germoplasma exótico, respectivamente, com base genética estreita e ampla; nos dois trabalhos observaram que $25 \%$ de germoplasma exótico permitiria uma combinação adequada entre produtividade de grãos e variabilidade genética para programas a médio e longo prazo; resultados semelhantes também foram encontrados por Prijic (1993). Eles concluíram que para o imediato uso de uma população e para se incrementar sua produtividade de grãos, existe pouca justificativa para se recorrer a parentais exóticos. O uso de parentais exóticos bem selecionados poderá ser estratégia para assegurar variabilidade genética para programas de seleção recorrente a longo prazo. Zimback 
(1992) e Montaño-Velasco (1994) discutem amplamente o uso de germoplasma exótico nos programas de melhoramento genético da soja.

O procedimento clássico no melhoramento de espécies autógamas é o cruzamento de dois parentais elites, para logo em seguida, desenvolver linhagens homozigóticas através da autofecundação das progênies por várias gerações. As linhagens superiores são identificadas por testes de produtividade e usadas como novos cultivares e também como parentais de novos cruzamentos. Esse método tem apresentado várias desvantagens: limitado "pool" de genes é usado em cada cruzamento; são necessários vários anos para a identificação e teste das linhagens, levando-se de 8 a 10 anos antes que elas possam ser novamente usadas como parentais para o próximo ciclo de seleção; e o incremento na produtividade por ano pode ser muito pequeno (Rose et al., 1992).

A seleção recorrente não tem sido usada amplamente no melhoramento de plantas autógamas por várias razões. Entre elas, a dificuldade em algumas espécies, como a soja, da polinização manual e o baixo número de sementes obtidas de cada polinização (Burton \& Caver, 1993). No entanto, alguns pesquisadores têm obtido sucesso em incrementar a produtividade de grãos em soja através da seleção recorrente (Kenworthy \& Brim, 1979; Sumamo \& Fehr, 1982; Piper \& Fehr, 1987). Em seus trabalhos, estes autores fizeram todas as polinizações manualmente. Porém, com o descobrimento da macho-esterilidade genética na soja criou-se a oportunidade de produzir a recombinação (etapa necessária no esquema da seleção recorrente), via 
polinização de plantas macho-estéreis por insetos. As principais vantagens de se usar seleção recorrente são: cada ciclo de seleção pode ser completado em até dois anos, dependendo da unidade de teste e recombinação e, as melhores linhagens são recombinadas tão logo elas sejam identificadas (Brim \& Stuber, 1973; Burton \& Brim, 1981; Carver et al., 1986; St. Martin, 1981; Nelson, 1987).

Existem vários sistemas de cruzamentos que podem ser usados para sintetizar a população básica para a seleção recorrente, entre eles: cruzamentos dialélicos, cruzamentos em cadeia, cruzamentos múltiplos e cruzamentos biparentais. Fatmi et al. (1992) compararam esses quatro sistemas com respeito à manutenção de alelos, quantidade de recombinação e a variabilidade genética disponível em cada população. Os autores intercruzaram dez linhagens isogênicas que diferiam em alelos para 12 locos, não encontrando diferenças na variabilidade e na quantidade de recombinação entre as populações. Concluíram que o método de cruzamento pode ser escolhido com base nos recursos disponíveis para sua implementação e que, neste caso, o método mais apropriado seria o de cruzamentos em cadeia.

O esquema de cruzamentos em cadeia tem vantagem sobre o esquema de cruzamentos dialélicos quando o número de genótipos avaliados é muito grande ( $\geq 10$ ). Isso porque para a obtenção de todos os cruzamentos dialélicos possíveis [n(n-1)/2] esse método torna-se inviável comparado ao esquema de cruzamentos em cadeia que inclui apenas n cruzamentos (Freire Filho, 1988). 


\subsection{Estimativas de parâmetros genotípicos e fenotípicos em soja}

As estimativas de parâmetros genotípicos e fenotípicos auxiliam aos melhoristas no momento de tomar as decisões a respeito da escolha do método de melhoramento e do modo de condução e de seleção das populações segregantes, permitindo aos melhoristas anteverem as possibilidades de sucesso nos programas de melhoramento (Ramalho et al., 1993). Entre os parâmetros mais importantes pode-se mencionar o coeficiente de herdabilidade, coeficiente de variação genética, ganho genético esperado com a seleção e a associação entre os caracteres, sendo que as estimativas desses parâmetros são de maior valor quando baseados em genótipos avaliados sob diferentes ambientes como anos e locais (Kwon \& Torrie, 1964).

Segundo Falconer (1989), os parâmetros estimados são propriedade não somente de um caráter, mas também da população, do ambiente ao qual os genótipos estão sujeitos e da forma em que o fenótipo é medido. Esses parâmetros dependem da magnitude de outras estimativas que têm recebido atenção dos geneticistas quantitativos e que interessam aos melhoristas: 1) variâncias genéticas (aditiva, dominante e epistáticas); 2) variâncias das interações $\mathrm{G} \times \mathrm{E}$, as quais podem afetar as estimativas dos parâmetros genéticos e fenotípicos (Robinson \& Cockerham, 1965; Falconer, 1989).

Como mencionado anteriormente, vários estudos têm mostrado que na soja o principal componente da variação genética para a maioria dos caracteres de importância econômica é a variância aditiva, com pequena contribuição da variância 
epistática do tipo aditiva $\mathrm{x}$ aditiva. Assim, também, vários autores têm apresentado estimativas de herdabilidade para os diferentes caracteres desta cultura, conforme é mostrado no Apêndice 1. Existe uma ampla variação para as estimativas obtidas para um dado caráter. Segundo Johnson et al. (1955), os diferentes métodos empregados para estimar herdabilidade não necessariamente estimam a mesma coisa, por exemplo, os métodos dos componentes de variância e o da regressão para estimar herdabilidade de plantas $\mathrm{F}_{2}$, estimam a mesma coisa somente se todos os efeitos gênicos forem aditivos. A natureza da unidade de seleção (planta, parcela, média de várias parcelas, etc) e os erros de amostragem também influenciam grandemente a magnitude das estimativas de herdabilidade. Por isso, qualquer comparação de estimativas obtidas, em diferentes situações, deve incluir uma cuidadosa avaliação dos métodos, genótipos e ambientes empregados.

Apesar da variação observada para os valores de herdabilidade (Apêndice 1) pode ser verificado que: as estimativas de herdabilidade para produtividade de grãos são menores e mais variáveis do que para outros caracteres em soja (Bartley \& Weber, 1952; Johnson et al., 1955; Hanson \& Weber, 1962; Anand \& Torrie, 1963; MontañoVelasco, 1994; Farias Neto, 1995; Santos et al., 1995a); as herdabilidades para altura da planta, maturidade e florescimento são, em geral, maiores do que aquelas para acamamento (Bartley \& Weber, 1952; Johnson et al., 1955; Anand \& Torrie, 1963; Know \& Torrie, 1964; Smith \& Weber, 1968; Mansur et al., 1993; Farias Neto, 1995); para porcentagem de proteína e óleo as herdabilidades são, em geral, altas (Smith \& 
Weber, 1968; Openshaw \& Hadley, 1984; McKendry et al., 1985; Malik \& Singh, 1987; Mansur et al., 1993; Orf \& Helms, 1994); e as estimativas para produtividade de óleo, por ser obtido como o produto da produtividade de grãos e porcentagem de óleo, são também baixas e muito variáveis (Zimback, 1992; Montaño-Velasco, 1994; Farias Neto, 1995). Isto serve para assinalar que a produtividade de grãos é um caráter de manuseio mais difícil e que, no processo seletivo, maiores cuidados devem ser tomados, especialmente no que se refere à geração em que se dará esse processo, assim como ao tamanho da população e aos cuidados experimentais; isto é, deve-se escolher criteriosamente o delineamento atentando-se para o tamanho da parcela e os demais cuidados necessários à condução do experimento (Ramalho et al., 1993).

Johnson et al. (1955) afirmaram que decisões práticas nos programas de melhoramento são baseadas na magnitude da variância herdável. A herdabilidade indica a eficiência com que a seleção de um genótipo pode ser realizada com base no seu comportamento fenotípico. Se a herdabilidade for de $100 \%$, o valor fenotípico será a indicação perfeita do valor genotípico; mas ainda nesta situação hipotética, o valor da herdabilidade por si mesma, não provê a indicação da quantidade do ganho genético que resultaria da seleção dos melhores indivíduos, devido que a variância genotípica pode ser muito pequena. Portanto, a validade das estimativas de herdabilidade é incrementada quando acompanhadas do diferencial de seleção (a quantidade que a média das linhagens selecionadas excede a média da população original) e do ganho genético (comumente obtido como o produto da herdabilidade pelo diferencial de seleção). 
Por outro lado, Lal \& Haque (1972) indicaram que o coeficiente de variação genética ajuda na obtenção da amplitude da diversidade genética num caráter e proporciona uma via para comparar a variabilidade genética nos caracteres quantitativos. No entanto, não é possível estimar a variação herdável somente com o coeficiente de variação genética, pelo que esses autores sugeriram que o coeficiente de variação genética, junto com as estimativas de herdabilidade, apresentaram um melhor panorama da quantidade de avanço esperado pela seleção.

Vencovsky (1987) estabeleceu um índice de variação genética (b), o qual quantifica a proporção da variabilidade genética em relação à variabilidade ambiental e é obtido pelo quociente entre o coeficiente de variação genética e o coeficiente de variação experimental. Quando b aproxima-se de 1, tem-se o indicativo de uma situação muito favorável para a seleção.

Outro parâmetro importante para o melhorista é o coeficiente de correlação que mede a associação entre os caracteres observados numa cultura. $\mathrm{O}$ estudo da natureza e magnitude das relações existentes entre caracteres é evidentemente importante, pois, no melhoramento em geral, a preocupação é aprimorar o material genético não para caracteres isolados, mas para um conjunto destes, simultaneamente. Além disso, é sempre importante saber como o melhoramento de uma característica pode causar alterações em outras (Vencovsky \& Barriga, 1992).

A correlação é provocada por fatores genéticos e ambientais, sendo que no melhoramento a associação de maior importância é a genética (Vencovsky \& 
Barriga, 1992). A correlação genética pode ser causada por efeitos pleiotrópicos dos genes ou pelo desequilíbrio de ligação. No último caso, a correlação genética é transitória e ocorre, principalmente, nas primeiras gerações de populações de plantas obtidas de cruzamentos de parentais geneticamente divergentes (Falconer, 1989).

No Apêndice 2 são apresentadas algumas estimativas de correlações genotípicas e fenotípicas obtidas por vários autores. Em soja, como em outras espécies e igualmente aos outros parâmetros como herdabilidade, as estimativas das correlações entre os caracteres são muito variáveis, mesmo considerando diferentes genótipos num mesmo local, ou o mesmo material avaliado em vários locais ou anos. Isso ocorre porque a correlação é função da variância genética manifestada para cada um dos caracteres e da precisão experimental com que os mesmos foram avaliados (Ramalho et al., 1993).

Em geral, na soja, a correlação genotípica tem sido maior do que a fenotípica, indicando que a expressão fenotípica é diminuída frente as interferências do ambiente. Embora exista variabilidade nos dados, eles indicam que a produtividade de grãos está associada positivamente à altura da planta na maturidade, número de dias para a maturidade, período de frutificação, peso de semente e acamamento (Weber \& Moorthy, 1952; Johnson et al., 1955; Anand \& Torrie, 1963; Kwon \& Torrie, 1964). O teor de proteína está alta e negativamente associado com os caracteres teor de óleo e produtividade de grãos. A associação positiva encontrada pela maioria dos autores entre produtividade de grãos, altura da planta e maturidade indica uma certa dificuldade em selecionar plantas precoces e produtivas (Montaño-Velasco, 1994; Santos et al., 
1995a; Farias Neto, 1995). A maioria dos autores têm também encontrado que o caráter teor de óleo apresenta correlações positivas, porém quase nulas, com os outros caracteres.

Uma das implicações mais importantes das correlações entre caracteres é com respeito à resposta correlacionada à seleção. Assim, segundo Vencovsky \& Barriga (1992), vale a pena indagar em quanto será alterada a média do caráter $\mathrm{Y}$ quando se seleciona para o caráter X. Anand \& Torrie (1963), utilizando correlações parciais e múltiplas encontraram que, quando o número de plantas permanece constante, o número de vagens por planta e número de sementes por vagem estiveram mais relacionados à produtividade de grãos do que o caráter peso de semente. No entanto, Santos et al. (1995a) encontraram uma baixa associação entre produtividade de grãos e número de sementes por vagem. Santos et al. (1995b) desdobraram os coeficientes de correlação entre nove caracteres quantitativos em efeitos diretos e indiretos, considerando um diagrama em cadeia e os modelos aditivos e multiplicativos da produtividade de grãos, além dos seus componentes primários. Eles encontraram que o número de vagens por planta, como componente primário, e dias para a maturidade, altura da planta na maturidade e número de nós no florescimento, como componentes secundários, aparecem como os mais importantes no processo de seleção indireta para aumento da produtividade de grãos em soja.

Farias Neto (1995) ao estudar as correlações entre os caracteres produtividade de grãos, porcentagem de óleo e produtividade de óleo (produtividade de 
grãos x \%óleo), encontrou que a correlação entre produtividade de grãos e produtividade de óleo foi de 0,98 . Tal informação associada à pequena correlação entre produtividade de óleo e porcentagem de óleo $\left(\mathrm{r}_{\mathbf{G}}=0,17\right)$ e pequena variabilidade no caráter porcentagem de óleo indicam que a seleção indireta para produtividade de óleo seria mais eficiente via produtividade de grãos do que via porcentagem de óleo. Brim (1973) assinala que a associação entre os componentes químicos da semente com a produtividade de grãos varia muito de um cruzamento para outro e conclui que a correlação entre a porcentagem de óleo e a porcentagem de proteína é um pobre indicador da produtividade de grãos.

\subsection{Melhoramento para teor de óleo}

A soja ocupa um lugar importante no mercado mundial devido ao seu teor de óleo e proteína, pelo que existe um grande interesse em desenvolver cultivares superiores nesses atributos acompanhados com alta produtividade de grãos (Tinius et al., 1993). Os cultivares de soja nos Estados Unidos contêm aproximadamente $41 \%$ de proteína, $21 \%$ de óleo e $11 \%$ de carboidratos solúveis (Openshaw \& Hadley, 1984). No Brasil, os dados obtidos para o Estado de São Paulo apresentam, em média, 37\% de proteína e $22 \%$ de óleo (Teixeira et al., 1984).

Vários programas de melhoramento visando aumentar tanto a quantidade como a qualidade do teor de óleo nas sementes de soja são citados na literatura. Brim 
(1973) relata que na Região Sul dos Estados Unidos, o aumento médio de óleo foi de $1 \%$, enquanto que na Região Norte foi de $0,6 \%$ de 1960 a 1970. Na China, Zhang \& He (1991) estudaram o impacto do melhoramento no teor de óleo em 148 cultivares, encontrando aumentos de $1,3,0,8$ e $0 \%$ em genótipos precoces, intermediários e tardios, respectivamente, durante um período de 40 anos. Essas pequenas taxas de incremento podem ser atribuídas ao fato dos programas de melhoramento terem como meta principal o aumento na produtividade de grãos e a resistência a doenças (Burton \& Brim, 1981).

Orf \& Helms (1994) afirmam que o valor da soja para os processadores está determinado principalmente pelo conteúdo de proteína e óleo das sementes, enquanto que para o produtor é determinado pela produtividade de grãos. A avaliação de linhagens experimentais para proteína e óleo é custosa, pelo que o melhorista precisa considerar como a seleção para produtividade de grãos pode ser combinada com a seleção para teor de proteína e óleo, visando maximizar o valor total por hectare (VTH). Esses autores estudaram a seleção de linhagens a partir de populações segregantes para produtividade de grãos, teor de proteína, teor de óleo, soma de proteína e óleo, produtividade de proteína, produtividade de óleo e VTH, para determinar que critério indentifica linhagens com alto VTH. Eles encontraram, entre outros resultados, que a seleção para VTH, numa população que teve maior variância genética para produtividade de grãos e teor de óleo, e uma variância menor para teor de proteína, identificaria linhagens com alta produtividade de grãos e alto teor de óleo em relação à média da população. Essas linhagens teriam um VTH maior do que 
linhagens selecionadas somente para produtividade de grãos, devido ao maior valor por kilograma de semente e a alta produtividade de grãos. Logicamente, isso poderia ser usado comercialmente se existisse no mercado um maior preço para sementes com maior teor de óleo.

Leffel (1989), citado por Orf \& Helms (1994) sugeriu que, baseado em trabalhos anteriores, o resultado mais provável do contínuo melhoramento para alta produtividade na soja será um alto teor de óleo e baixo teor de proteína. Isso pode ser explicado pela correlação negativa entre produtividade de grãos e teor de proteína e pela correlação positiva, embora pequena, entre produtividade de grãos e teor de óleo.

O óleo de soja contém cinco ácidos graxos: Palmítico (11\%), Esteárico (3\%), Oléico (22\%), Linoléico (56\%) e Linolênico (8\%). O ácido linolênico tem sido associado com pouca estabilidade e com o sabor e aroma ranços (Wilcox, 1985). Para ser aceitável pelo consumidor, o óleo de soja é refinado, branqueado e hidrogenado. No entanto, durante a armazenagem, o sabor e o aroma ranço podem retornar por um processo de reversão. A oxidação do ácido linolênico tem sido assinalada como o causador dessa reversão.

O óleo de soja hidrogenado contém maior concentração de ácido oléico (47\%) e menor concentração dos ácidos linoléico (37\%) e linolênico (3\%), comparado com o óleo cru da semente, exibindo assim, melhor qualidade. Sem dúvida, o custo da hidrogenação é alto, pelo que se tem enfatizado a importância de aumentar a qualidade do óleo cru da soja através do melhoramento genético (Carver et al., 1986). Até há 
alguns poucos anos, os programas de melhoramento com esse objetivo, procuraram reduzir o teor do ácido linolênico, utilizando, principalmente, duas metodologias que são a mutação e a seleção recorrente (Brim \& Stuber, 1973; Tinius et al., 1993).

Outra alternativa que tem sido estudada pelos melhoristas de soja para aumentar a qualidade do óleo na semente, é a eliminação genética das enzimas lipoxigenases, também encontradas na semente. As lipoxigenases são uma classe de enzimas que catalizam a hidroperoxidação de lipídios poli-insaturados como os ácidos linoléico e linolênico, convertendo-os em compostos voláteis causadores dos sabores indesejáveis (Pfeiffer et al., 1992). Segundo esses autores, têm sido caracterizadas três isoenzimas lipoxigenases nas sementes da soja.

Por outro lado, atualmente, o papel do ácido linolênico e das enzimas lipoxigenases está sendo discutido do ponto de vista nutricional. Segundo Kretchmer \& Kretchmer (1987), tem-se confirmado a participação dos ácidos graxos insaturados na redução do colesterol do sangue, como precursores de substâncias essenciais ao bom funcionamento da rede vascular e de plaquetas, evitando a formação de trombose e, também, na manutenção da integridade da pele.

Com base nesse último critério, o óleo de soja pode ser considerado de ótima qualidade dietética em função do alto teor de ácidos graxos insaturados (85\%), principalmente o ácido linolênico, que fisiologicamente não é sintetizado pelo organismo humano, motivo pelo qual é chamado de ácido graxo essencial (Montaño-Velasco, 1994). 


\subsection{Interação Genótipos x Ambientes (G x E)}

O fenótipo de cada indivíduo de uma população reflete as influências genéticas e não genéticas sobre seu desenvolvimento. As influências não genéticas são determinadas pelo ambiente, o qual pode estar associado a uma localidade ou a um certo período de tempo (Vernetti et al., 1990). Segundo Cruz \& Regazzi (1994) a avaliação da interação genótipos $x$ ambientes ( $G \times 1$ E) torna-se de grande importância no melhoramento, pois, no caso de sua existência, há possibilidade de o melhor genótipo em um ambiente não o ser em outro. Este fato influencia o ganho na seleção e dificulta a recomendação de genótipos com ampla adaptabilidade.

Os melhoristas de plantas podem orientar os programas de seleção para obter cultivares que são adaptados a uma ampla gama de ambientes ou obter cultivares adaptados a ambientes específicos. Pequena ou nula interação $\mathrm{G} \times \mathrm{E}$ favorece a primeira situação, enquanto interações significativas favorecem a segunda alternativa (Soares et al., 1995). No entanto, na maioria dos programas de melhoramento, a capacidade para desenvolver linhagens de alta produtividade e estáveis, a partir de uma população, é uma meta primária (Ablett et al., 1994).

Existem vários estudos da interação $\mathrm{G}$ x E na cultura da soja indicando que os caracteres quantitativos são afetados por locais e épocas de semeadura (Rose, 1987; Vernetti et al., 1990; Van Sanford et al., 1993; Ablett et al., 1994; Dashiell et al., 1994; Orf \& Helms, 1994; Scott et al., 1994; Toledo et al., 1994; Pfeiffer et al., 1995). 
Tipicamente, os testes preliminares das linhagens nas gerações iniciais de seleção são conduzidos em uma ou duas localidades, com objetivo de se identificar as linhagens com ampla adaptação. Idealmente, as localidades primárias deveriam ser selecionadas pela sua alta correlação com o comportamento em uma gama ampla de ambientes. Na prática, no entanto, os locais dos testes primários são freqüentemente selecionados pela localização do campo experimental (ou em fazendas de produtores que atuam como cooperadores) e a correlação entre as médias genotípicas das progênies nestes ambientes com a média genotípica em todos os ambientes é baixa (Van Sanford et al., 1993). O grande número de genótipos nos testes preliminares obriga o melhorista a fazer a classificação dos genótipos só nas etapas avançadas (Scott et al., 1994).

Segundo Scott et al. (1994), a combinação de estratégias de seleção e restrição de recursos em muitos programas de melhoramento obriga os melhoristas a testar os genótipos em ensaios preliminares, num só ambiente. Esses autores, entretanto, ao estudar genótipos de soja pertencentes aos grupos de maturidade III e IV, encontraram que a seleção baseada em ambientes individuais foi uma pobre medida de comportamento da média geral através dos ambientes. Por outro lado, Zavala-Garcia et al. (1992), trabalhando com sorgo (Sorghum bicolor (L.) Moench), encontraram que o comportamento dos genótipos a partir da média de vários ambientes foi uma pobre medida do comportamento em ambientes individuais.

Tem-se encontrado que na soja, a contribuição dos genótipos sobre a variância da interação $\mathrm{G} \times \mathrm{E}$ depende da produtividade desses genótipos. Assim, Baihaki et al. (1976) concluíram que a seleção pode ser feita em um só ambiente, sem muitos 
riscos de descartar linhagens de alta produtividade, já que, aproximadamente $50 \%$ da interação $\mathrm{G}$ x E é devida ao grupo de linhagens de baixa produtividade. Esses resultados também foram encontrados por Scott et al. (1994), que dividiram os genótipos de dois grupos de maturidade (III e IV) em grupos de alta, média e baixa produtividade para estudar a contribuição destes sobre o total da variância da interação G x E. Os autores encontraram que, no grupo de maturidade III, os genótipos de baixa produtividade tiveram uma maior proporção na variância da interação, seguidos pelos genótipos de média produtividade e, finalmente, os de alta produtividade. No grupo de maturidade IV, os genótipos de alta e média produtividade tiveram igual proporção na interação G x E, mas, ambos foram inferiores aos genótipos de baixa produtividade, concluindo que é possível identificar uma grande proporção de genótipos de alta produtividade ainda na presença de interação G x E. Por outro lado, Adegoke \& Frey (1987), trabalhando com aveia, encontraram que os genótipos de produtividade mais alta contribuíram mais para a variância da interação $\mathrm{G} \times \mathrm{E}$ do que os de média e baixa produtividade.

Um dos aspectos importantes a considerar no estudo da interação $\mathrm{G}$ x E, é que esta reduz a correlação entre o fenótipo e seu genótipo, restringindo a validade das inferências sobre seu comportamento; tanto do ponto de vista do comportamento genético como da herança de caracteres quantitativos (Vernetti et al., 1990). Segundo Dashiell et al. (1994), a variação na magnitude da herdabilidade de uma localidade para outra sugere que os genótipos não reagem da mesma forma em todas as localidades, possivelmente devido ao efeito ambiental ou à interação $\mathrm{G} x$ E. Por outro lado, quando se obtém estimativas de parâmetros genéticos para ambientes individuais, essas 
estimativas são viesadas pelo confundimento com a interação $\mathrm{G} \times \mathrm{E}$, que não pode ser estimada (Scott et al., 1994).

Allen et al. (1978) concluíram que ambientes favoráveis ou que não causam estresse tendem a produzir variâncias genéticas maiores e altas taxas de ganho genético, quando comparados a ambientes desfavoráveis ou estressantes. Esses resultados também foram confirmados por Soares et al. (1995) que, trabalhando com arroz (Oriza sativa L.), encontraram que ambientes de alta produtividade são mais apropriados para selecionar genótipos superiores. Além disso, os ambientes favoráveis permitem maior discriminação entre linhagens devido à maior variabilidade genética entre elas. Por outro lado, Scott et al. (1994) concluíram que o nível de fertilidade dos ambientes não influi substancialmente na variância genética entre os genótipos.

Rosielle \& Hamblin (1981) mostraram que a seleção teórica para alta produtividade, sob ambientes estressantes, resulta em médias de produtividade baixas em ambientes favoráveis. Os autores recomendaram que, para se incrementar a produtividade em ambientes estressantes, o melhorista deve selecionar para alta produtividade nestes ambientes só se a média dos genótipos for elevada em uma ampla gama de ambientes. Assim, a seleção basear-se-á na média de produtividade sob ambos os ambientes, favoráveis e desfavoráveis.

As avaliações dos genótipos através de localidades e anos, para a maioria das plantas, usualmente mostram interação genótipos $\mathrm{x}$ localidades, genótipos $\mathrm{x}$ anos $\mathrm{e}$ genótipos $\mathrm{x}$ localidades $\mathrm{x}$ anos. Porém, para alguns caracteres a importância das interações relativas aos efeitos principais dos genótipos, será menor do que para outros; 
é o caso, por exemplo, de dias para o florescimento e produtividade de grãos. Freqüentemente, a interação genótipos $\mathrm{x}$ anos é maior do que a genótipos $\mathrm{x}$ locais; também, normalmente, a interação genótipo $\mathrm{x}$ locais $\mathrm{x}$ anos é menor do que as duas interações anteriores. Além disso, ao estimar os componentes de variância para os efeitos principais e as interações, usualmente se encontra que o componente de variância para os genótipos é maior do que para as interações (Zhou \& Zhu, 1994).

Rose (1987) avaliou sete genótipos de soja na Austrália, em várias épocas de semeadura, encontrando que a produtividade de grãos foi afetada pelas datas de semeadura, genótipos e a interação genótipos $\mathrm{x}$ datas de semeaduras. $\mathrm{O}$ efeito das datas de semeadura foi nulo para o caráter peso de semente e a semeadura tardia diminuiu significativamente a porcentagem de óleo na semente em $1,7 \%$. Num outro estudo, Wilcox \& Cavins (1992) estudaram o efeito de datas de semeadura, durante cinco anos nos Estados Unidos, sobre a composição dos ácidos graxos na semente de soja e encontraram que a composição destes ácidos não foi afetada pelas datas de semeadura, em dois dos anos. Esses resultados foram similares aos encontrados por Schnebly \& Fehr (1993). Toledo et al. $(1993,1994)$ têm estudado genótipos de soja em diferentes épocas de semeadura para avaliar a resposta ao fotoperíodo e o mecanismo genético que controla essa resposta; encontraram interação genótipos $\mathbf{x}$ ambientes para a resposta ao fotoperíodo.

Ablett et al. (1994) avaliaram 20 linhagens $F_{4}$ de soja com crescimento semideterminado e $20 \mathrm{~F}_{4}$ com crescimento indeterminado, em oito locais do Norte dos 
Estados Unidos. Encontraram alta significância para a interação genótipos $\mathbf{x}$ locais em produtividade de grãos e altura da planta, sendo que ambos os hábitos de crescimento contribuíram igualmente à variância da interação $\mathrm{G} \times \mathrm{E}$. Dados similares foram obtidos por Dashiell et al. (1994). Os autores avaliaram 18 genótipos de soja, em cinco localidades da Nigéria, encontrando uma ampla variação na produtividade através das cinco localidades. Num outro estudo, Pfeiffer et al. (1995) estudaram 32 linhagens $F_{4}$ de soja, pertencentes ao grupo de maturidade I, em quatro localidades nos Estados de Kentucky e Minnesota nos Estados Unidos. Encontraram que para produtividade de grãos houve diferenças para a interação $\mathrm{G}$ x $\mathrm{E}$ dentro de cada estado, mas não para a interação genótipos x estados; já para os caracteres porcentagens de proteína e de óleo, a interação entre e dentro dos estados foi sempre significativa.

Schutz \& Bernard (1967) estimaram os componentes de variância da interação G x E em genótipos de soja dos grupos de maturidade $0, \mathrm{~V}$, VI e VII encontrando que para proteína e óleo, o comportamento da interação foi muito menor do que para a produtividade. Por outro lado, Kwon \& Torrie (1964) encontraram que a variância genotípica foi maior do que a interação $\mathrm{G} \times \mathrm{E}$ para todos os caracteres, exceto para a produtividade. Além disso, encontraram que a interação genótipos $\mathrm{x}$ anos foi maior do que a interação genótipos $\mathrm{x}$ locais e genótipos $\mathrm{x}$ locais $\mathrm{x}$ anos, para $\mathrm{o}$ caráter \% óleo. Assim mesmo, Zhou \& Zhu (1994) concluíram que, de forma geral, a variância devida aos genótipos foi maior do que a da interação genótipos x locais para todos os caracteres estudados. 
Um ponto importante no estudo da interação $\mathrm{G} \times \mathrm{E}$ é a sua estimação, a qual pode ser feita a partir de uma análise de variância. Porém, do ponto de vista do melhoramento, uma significância na fonte de variação $\mathrm{G} \times \mathrm{E}$, por si só, não diz muito (Vencovsky \& Barriga, 1992). Segundo Robertson (1959) e Cockerham (1963), quando um grupo de genótipos é avaliado em dois ambientes o quadrado médio da interação pode ser decomposto em duas partes:

$$
Q M_{G E}=(1 / 2)\left(\sqrt{Q M_{1}}-\sqrt{Q M_{2}}\right)^{2}+\left(1-r_{12}\right) \sqrt{Q M_{1} \cdot Q M_{2}} \quad \text { onde }
$$

$\mathrm{QM}_{\mathrm{GE}}$ é o quadrado médio da interação $\mathrm{G} \times \mathrm{E} ; \mathrm{QM}_{1}$ e $\mathrm{QM}$ são os quadrados médios referentes aos genótipos nos locais 1 e 2 , respectivamente; e $r_{12}$ é o coeficiente de correlação entre as médias (ajustadas) dos tratamentos, de um local para outro.

A primeira parte da equação é denominada de componente simples por ser devida apenas às diferenças na variabilidade entre os genótipos, dentro de locais. A segunda parte é denominada, de componente complexa, por ser fruto da falta de correlação entre o comportamento médio dos genótipos de um local para outro; esta é a parte da interação que tende a impedir uma seleção de genótipos promissores para ambos os ambientes simultaneamente (Vencovsky \& Barriga, 1992). Se a correlação é baixa, isso indica que o material superior em um ambiente, provavelmente, não terá o mesmo desempenho no outro, complicando o trabalho do melhorista (Ramalho et al., 1993). 


\section{MATERIAL E MÉTODOS}

\subsection{Material Experimental}

O material utilizado neste estudo consistiu em 999 progênies $F_{6: 3}$ (progênies $\mathrm{F}_{6}$ derivadas de uma planta $\mathrm{F}_{3}$ individual; significa que existe variabilidade genética entre as plantas de cada progênie) e 210 progênies $F_{7: 3}$ provenientes de 40 cruzamentos biparentais de soja envolvendo 40 parentais, sendo 30 genótipos adaptados e dez genótipos exóticos. Para a obtenção das progênies no ano agrícola de 1987/1988 os parentais foram divididos em dois grupos. Um grupo foi composto por dez genótipos exóticos e dez genótipos adaptados e outro por 20 genótipos adaptados. Em cada um dos grupos foram realizados 20 cruzamentos biparentais em cadeia circulante. No primeiro grupo os materiais exóticos foram intercalados com os adaptados de modo que cada cruzamento tinha $50 \%$ de genes exóticos e $50 \%$ de genes adaptados. Desse modo o primeiro grupo foi denominado de cadeia mista e o segundo grupo de cadeia adaptada (Apêndice 3).

Os 40 parentais foram selecionados mediante estudos de campo e através do método das genealogias (Vello, 1992; Zimback, 1992), baseando-se em suas 
características desejáveis como elevada produtividade de grãos, alta porcentagem de óleo na semente e pela sua diversidade genética. Além disso, esses parentais são portadores de genes para resistência a doenças como nematóide de cisto, cancro da haste e mancha olho-de-rã (Vello, 1995).

Foram utilizadas quatro testemunhas: 'Bossier', 'IAC-12', 'UFV-4' e 'IAC-Santa Maria-702', as quais são cultivares adaptados e de boa produtividade. $\mathrm{O}$ cultivar Bossier é de ciclo de maturação precoce com $21 \%$ de óleo; o cultivar IAC-12 é de ciclo precoce a intermediário com $21 \%$ de óleo; o cultivar IAC-Santa Maria 702 é de ciclo tardio e tem $19 \%$ de óleo; e o cultivar UFV-4 é de ciclo tardio com $24 \%$ de óleo aproximadamente.

\subsection{Ambientes de Condução dos Experimentos}

A condução dos experimentos, nas duas gerações, foi realizada nos campos experimentais da Fazenda Areão e da Estação Experimental de Anhembi, ambos pertencentes à Escola Superior de Agricultura "Luiz de Queiroz" (ESALQ) da Universidade de São Paulo (USP), localizados no município de Piracicaba, Estado de São Paulo. Piracicaba está situada a $22^{\circ} 42^{\prime} 30^{\prime \prime}$ de latitude Sul, $47^{\circ} 39^{\prime} 00^{\prime \prime}$ de longitude Oeste e à uma altitude de 540m acima do nível do mar. Nos Apêndices 4a e 4b são apresentadas as informações referente às temperaturas, umidades relativas médias, precipitação pluvial e fotoperíodo durante as fases experimentais (dados 
fornecidos pelo Departamento de Física e Meteorologia da ESALQ/USP). Além disso, os Apêndices 5a e 5b mostram os critérios utilizados para a interpretação de análises de solos para o Estado de São Paulo segundo Malavolta et al. (1989) e as análises de solo relativas às áreas de pesquisa de soja nos dois locais.

\subsection{Condução experimental e caracteres avaliados}

\subsubsection{Geração $F_{6: 3}$}

A semeadura das progênies $F_{6: 3}$ ocorreu na época de outono/inverno (denominada de Safrinha no Estado de São Paulo), nas datas 24 e 25/01/1994. Foram semeadas 999 progênies e quatro testemunhas empregando-se o delineamento em blocos ao acaso com duas repetições. Em cada repetição, os tratamentos foram arranjados em 26 conjuntos experimentais, sendo que as testemunhas apareceram em todos os conjuntos, fixadas sempre no meio de cada um deles. Para evitar efeito de competição desigual e facilitar a condução dos experimentos no campo, as progênies foram agrupadas segundo o ciclo de maturação e cruzamento, sendo que a aleatorização ocorreu só entre progênies dentro de cada cruzamento.

A parcela experimental consistiu de uma fileira de dois metros, espaçadas de 50 centímetros, semeando-se 30 sementes por metro. Os conjuntos dentro de cada repetição foram separados por um caminho de 60 centímetros. 
O preparo do solo foi similar para os dois locais e consistiu de uma aração e duas gradagens. A adubação foi feita no sulco, aplicando-se $25 \mathrm{~g}$ da fórmula 4-20-20 por metro, com inoculação da semente, usando-se o inoculante comercial Bradyrhizobium japonicum. Aconteceram duas irrigações por aspersão, controle de pragas e ervas daninhas.

Os caracteres avaliados foram:

- Número de dias para a maturidade (NDM): contados a partir da data de semeadura até a data em que $50 \%$ das plantas da parcela apresentaram $95 \%$ das vagens maduras.

- Altura da planta na maturidade (APM): medida em centímetros, da superfície do solo até o ápice da haste principal em uma planta representativa da parcela.

- Valor agronômico (VA): é uma avaliação visual, na maturidade, de um conjunto de caracteres como quantidade de vagens formadas, vigor e sanidade da planta, debulha prematura das vagens, altura da planta, acamamento e retenção foliar. Foi usada uma escala de notas de 1 a 5 , sendo que a nota 1 corresponde a plantas com VA baixo e a nota 5 a plantas com valor agronômico excelente. 
- Produtividade de grãos (PG): avaliado após a trilhagem das plantas e secagem dos grãos $(13 \%)$, em gramas por parcela (gramas $\left./ 1,0 \mathrm{~m}^{2}\right)$.

- Porcentagem de óleo (\%OL): avaliado pela metodologia de espectometria de ressonância nuclear magnética (NMR), utilizando-se o aparelho de NMR desenvolvido pela EMBRAPA-UAPDIA-São Carlos, em convênio com a FINEP e o Departamento de Genética da ESALQ-USP. Foi usada uma amostra de sementes por parcela com um peso entre 1,70 e 1,80 gramas, o que compreende de 17 a 19 sementes. Mais detalhes sobre o uso do NMR foram reportados por Montaño-Velasco (1994).

- Produtividade de óleo (PO): obtida pelo produto entre a produtividade de grãos por parcela e a porcentagem de óleo nas sementes.

Após a obtenção e análise dos dados experimentais foram selecionadas 210 progênies (120 precoces, 45 intermediárias e 45 tardias) para originar a geração $F_{7: 3}$. A porcentagem de seleção para as progênies precoces, intermediárias e tardias foi de 22,28 e $25 \%$, respectivamente, com base nas médias das progênies nos dois locais. Os critérios de seleção utilizados foram em ordem de importância: Produtividade de grãos (PG), Porcentagem de óleo (\%OL), Valor Agronômico (VA), Número de dias para a maturidade (NDM) e Altura da planta na maturidade (APM). 


\subsubsection{Geração $F_{7: 3}$}

As progênies $F_{7: 3}$ selecionadas foram avaliadas no ano agrícola de 1994/1995. A semeadura ocorreu na época de verão (cultivo normal no Estado de São Paulo), nas datas 22 e 28/10/1994.

As 120 progênies consideradas de ciclo precoce foram divididas em dois grupos de 60 cada. Desse modo, constituíram-se quatro grupos de genótipos: dois grupos de progênies precoces, um grupo de intermediárias e um grupo de tardias.

O delineamento experimental utilizado foi em látice simples com duas repetições para cada um dos quatro grupos de genótipos. Mais especificamente: dois látices simples $8 \times 8$ para as progênies precoces (cada um com 60 progênies e quatro testemunhas); um látice simples $7 \times 7$ para as intermediárias (45 progênies e quatro testemunhas) e outro látice simples $7 \times 7$ para as tardias (45 progênies e quatro testemunhas).

Assim, em 1994/95, foram conduzidos oito experimentos em látice, sendo quatro experimentos na Fazenda Areão e outros quatro na Estação Experimental de Anhembi. A parcela experimental em todos os oito experimentos consistiu de duas fileiras de cinco metros, com espaçamento de 50 centímetros entre fileiras. Entre duas parcelas foi deixada uma fileira sem semear. Dentro de cada sulco, as fileiras foram separadas por um caminho de 50 centímetros. 
Os procedimentos adotados na instalação (preparação do solo, adubação) e condução dos experimentos foram os mesmos empregados na avaliação da geração $\mathrm{F}_{6: 3}$. Os caracteres avaliados também foram os mesmos da geração anterior, com a diferença de que para o caráter porcentagem de óleo (\%OL) foram obtidas duas amostras por parcela para maior precisão.

Após a obtenção e análise dos dados foram selecionadas 74 progênies $F_{7: 3}$ (33 precoces, 21 intermediárias e 20 tardias). A porcentagem de seleção para as progênies precoces, intermediárias e tardias foi de 28,47 e $44 \%$. Foram utilizados os mesmos critérios de seleção da geração $\mathrm{F}_{6: 3}$.

\subsection{Análises estatístico-genéticas}

\subsubsection{Geração $F_{6: 3}$}

\subsubsection{Análises individuais de variância}

Devido à perda e descarte de parcelas, foram avaliadas e analisadas 897 progênies (555 precoces, 161 intermediárias e 181 tardias). Por outro lado, pelo fato da aleatorização ter sido realizada somente entre progênies dentro de cruzamentos, em cada local foi realizada uma análise de variância, em blocos aumentados, para cada 
repetição, utilizando-se o pacote computacional MAPGEN, desenvolvido por Ferreira (1993)1. O modelo matemático utilizado para todos os caracteres foi:

$$
Y_{i j}=u+b_{j}+t_{i(j)}+e_{i j} \text {, onde: }
$$

$\mathrm{Y}_{\mathrm{ij}}: \quad$ observação do tratamento i no bloco $\mathrm{j}$;

u : média geral;

$b_{j}: \quad$ efeito do bloco $\mathrm{j}$ com $\mathrm{j}=1,2, \ldots, \mathrm{J}$;

$t_{i(1)}$ : efeito do tratamento $\mathrm{i}$ com $\mathrm{i}=1,2, \ldots, \mathrm{I}$ dentro do bloco $\mathrm{j}$. Essa fonte de variação foi decomposta em efeitos entre tratamentos regulares (progênies) dentro de blocos $(\mathrm{R} / \mathrm{B})$, entre tratamentos comuns (testemunhas $=\mathrm{T}$ ) e R/B vs $\mathrm{T}$; $\mathrm{e}$

$\mathrm{e}_{\mathrm{ij}}$ : $\quad$ erro experimental intrabloco associado à parcela do bloco $\mathrm{j}$ que recebeu o tratamento i.

Logo, para cada repetição foram obtidas as médias ajustadas de cada progênie para todos os caracteres, ao nível da parcela, dentro de cada bloco. 0 MAPGEN fornece as médias ajustadas, utilizando a expressão

$$
\mathrm{Y}_{\mathrm{aj}}=\mu+\mathrm{t}_{\mathrm{i}()}
$$

onde:

\footnotetext{
1 "MAPGEN", não publicado. DANIEL FURTADO FERREIRA, Professor do Departamento de Ciências Exatas da Universidade Federal de Lavras (UFLA).
} 
$\mathbf{Y}_{\mathrm{aj}}: \quad$ valor ajustado do caráter;

$\mu$ : $\quad$ média do caráter;

$t_{i()}: \quad$ é o efeito ajustado do tratamento i, dentro do bloco $\mathrm{j}$.

No modelo da análise de variância, o efeito ti(f) é obtido sob a restrição ponderada

$$
\sum_{i(0)} t_{i())} r_{i}=0
$$

onde $r_{i}$ é o número de repetições para os tratamentos (regular ou comum, dentro do bloco j). Assim também o efeito do bloco $\left(b_{\mathrm{j}}\right)$ é ponderado pelo número de parcelas de cada bloco

$$
\sum_{j} n_{j} b_{j}=0
$$

sendo: $n_{j}$ o número de parcelas.

O quadrado médio do erro efetivo em cada repetição foi obtido utilizando a expressão:

$$
Q M E_{e f}=\left[1+\frac{1}{f+g-1}+\frac{f}{g(f+g-1)}+\frac{f \sum_{k=1}^{b} n_{k}^{2}}{g n^{2}(f+g-1)}-\frac{2 \sum_{k=1}^{b} n_{k}^{2}}{n(f+g-1)}+\frac{b \sum_{k=1}^{b} n_{k}^{2}}{n^{2}(f+g-1)}-\frac{Q M E}{}\right.
$$


onde:

$\mathrm{f}=$ número de tratamentos regulares;

$\mathrm{g}$ = número de testemunhas comuns;

$\mathrm{b}=$ número de blocos;

$\mathrm{n}_{\mathrm{K}}=$ número de tratamentos (regulares e testemunhas do bloco $\mathrm{k}$ );

$\mathrm{n}=$ número total de parcela;

QME = Quadrado Médio do Erro intrablocos.

O esquema da análise é apresentado na Tabela 1 e no Apêndice 6 é mostrada a estrutura e seqüência de comandos para operar com o pacote MAPGEN para o delineamento em blocos aumentados.

Após a obtenção das médias ajustadas para cada progênie e verificação da homogeneidade de variâncias residuais foi realizada uma análise em blocos casualizados, combinando-se as duas repetições em cada local, incluindo-se somente as progênies. $\mathbf{O}$ modelo utilizado foi:

$$
Y_{i j}=u+r_{j}+t_{i}+e_{i j}
$$

sendo:

$\mathrm{Y}_{\mathrm{i}}: \quad$ observação do tratamento i na repetição j;

u : média geral; 
$\mathrm{r}_{\mathrm{j}}$ : efeito de repetição $\mathrm{j} \operatorname{com} \mathrm{j}=1,2, \ldots, \mathrm{J}$;

$t_{i}$ : efeito do tratamento $i$ com $i=1,2, \ldots$, I. Essa fonte de variação foi decomposta em ciclos de maturidade ( 3 ciclos), cadeias de cruzamentos (mista e adaptada) dentro de ciclos, cruzamentos dentro de cadeias e ciclos; e progênies dentro de cruzamentos, cadeias e ciclos. Ao mesmo tempo, esse último quadrado médio foi decomposto em precoces, intermediárias e tardias; e

$\mathrm{e}_{\mathrm{ij}}$ : erro experimental associado à parcela da repetição $\mathrm{j}$ que recebeu o tratamento $\mathrm{i}$ (QM, da Tabela 2)

O esquema desta análise é apresentado na Tabela 2.

Para melhorar a precisão das estimativas dos parâmetros genéticos foi calculado um quadrado médio de erro efetivo médio $\left(\mathrm{QM}_{11}\right.$ da Tabela 2$)$ através da ponderação pelos graus de liberdade entre o quadrado médio do erro efetivo obtido das análises como blocos aumentados $\left(\mathrm{QM}_{10}\right)$ e o quadrado médio do erro obtido da análise das duas repetições utilizando as médias ajustadas $\left(\mathrm{QM}_{9}\right)$.

Para cada caráter avaliado, estimaram-se as médias ajustadas, variâncias fenotípicas e o intervalo de variação das progênies de cada cruzamento. A estimação das médias ajustadas das progênies, por cruzamento, foi feita através da média aritmética, após o ajuste de cada progênie. A estimação da variação fenotípica entre progênies dentro de cada cruzamento, foi feita empregando-se as médias ajustadas, obedecendo-se a expressão usual: 


$$
V_{c}=\frac{\sum\left(Y_{C}-\bar{Y}_{C}\right)^{2}}{n-1}
$$

e observando-se que o número de progênies por cruzamento foi diferente.

\subsubsection{Análise conjunta de variância}

Foi realizado o teste de homogeneidade de variâncias, obedecendo-se ao critério de relação máxima igual a 7 para o quociente entre a maior e a menor variância dos erros (Pimentel Gomes, 1990). Em seguida realizou-se uma análise conjunta de variância reunindo os dois locais, por meio das médias ajustadas para as progênies em cada repetição e em cada local. O modelo matemático utilizado foi:

$$
Y_{i j k}=u+r_{k j j}+l_{j}+t_{i}+(l t)_{i j}+e_{i j k}
$$

onde:

$\mathrm{Y}_{\mathrm{ijk}}$ : observação do tratamento $\mathrm{i}$ na repetição $\mathrm{k}$ no local $\mathrm{j}$;

u : média geral;

$r_{k / j}$ : efeito da repetição $k$ dentro do local $j, \operatorname{com~} k=1,2, \ldots, K$;

$\mathrm{l}_{\mathbf{j}} \quad$ : efeito do local $\mathbf{j}, \operatorname{com} \mathbf{j}=1,2, \ldots, \mathrm{J}$;

$t_{i}$ : efeito do tratamento $\mathrm{i}$ com $\mathrm{i}=1,2, \ldots, \mathrm{I}$; decomposto nos efeitos descritos anteriormente; 
$(\mathrm{lt})_{\mathrm{ij}}$ : efeito da interação locais $\mathrm{x}$ tratamentos com a decomposição respectiva descrita no ítem anterior;

$\mathrm{e}_{\mathrm{ijk}}$ : erro experimental associado à parcela da repetição $\mathrm{k}$ no local $\mathrm{j}$ que recebeu $\mathrm{o}$ tratamento i (erro efetivo médio geral).

O esquema da análise conjunta é apresentado na Tabela 3.

Os efeitos de locais, repetições e progênies dentro de cruzamentos foram considerados aleatórios. Embora as progênies tenham sido selecionadas na geração $F_{5: 3}$, elas foram consideradas aleatórias, pois a seleção praticada foi bastante branda (Farias Neto, 1995). Para a análise em blocos ao acaso e conjunta foi utilizado o pacote computacional SAS (Statistical Analysis System, 1985) instalado no Centro de Informática na Agricultura (CIAGRI) da ESALQ.

\subsubsection{Geração $F_{7: 3}$}

\subsubsection{Análises individuais de variância}

Como as análises em látice para cada grupo não apresentaram eficiência e, também, devido ao fato de todos os experimentos terem as mesmas testemunhas (comuns), os quatro experimentos, em cada local, foram analisados seguindo a metodologia proposta por Pimentel Gomes (1990). 
Essa metodologia corresponde ao uso de um delineamento em blocos incompletos com $v=214$ tratamentos (210 progênies e quatro testemunhas comuns), em blocos de $\mathrm{k}=$ parcelas, com duas repetições para as progênies (chamadas de tratamentos regulares).

Segundo Pimentel Gomes (1990), no caso geral, têm-se g grupos, cada um com $\mathbf{z}$ tratamentos regulares e $\mathbf{c}$ tratamentos comuns, num total de $\mathbf{v}=\mathbf{g z}+\mathbf{c}$ tratamentos. Cada grupo é ensaiado em $\mathbf{v}$ blocos de tamanho $\mathbf{k}=\mathbf{z}+\mathbf{c}$ parcelas. $\mathrm{O}$ esquema da análise é mostrado na Tabela 4. A fonte de variação devida a tratamentos ajustados foi decomposta em: ciclos; cadeias dentro de ciclos; cruzamentos dentro de cadeias e ciclos; progênies dentro de cruzamentos, cadeias e ciclos; testemunhas; progênies "versus" testemunhas. Além disso, as progênies foram decompostas em precoces, intermediárias e tardias.

Logo, as médias ajustadas das progênies, ao nível de parcela, foram obtidas da seguinte maneira:

- Para os tratamentos comuns: média aritmética dos dados respectivos, sem nenhum ajuste;

- Para os tratamentos regulares: observação em cada parcela da qual se subtrai uma correção $\mathrm{K}$ que se calcula da seguinte forma: $\mathrm{K}=$ (Média dos tratamentos comuns em um experimento em particular - média geral dos tratamentos comuns em todos os experimentos). 
Para cada caráter avaliado, estimaram-se as médias ajustadas, variâncias fenotípicas e o intervalo de variação das progênies de cada cruzamento, da mesma forma que em 3.4.1.1.

\subsubsection{Análise conjunta de variância}

Após realizar o teste de homogeneidade de variâncias foi feita uma análise conjunta para cada ciclo de maturação e de forma global, usando-se para isso as médias ajustadas de cada progênie.

O modelo matemático utilizado para a análise conjunta foi idêntico ao utilizado em 3.4.1.1. Para a análise individual e conjunta foi utilizada o Pacote Computacional SAS (Statistical Analysis System, 1985).

\subsubsection{Parâmetros Genéticos}

\subsubsection{Componentes de variância, herdabilidade, coeficiente de variação genética e índice de variacão genética}

Para cada geração, foram obtidas as estimativas das variâncias genotípicas, das interações, herdabilidade, coeficiente de variação genética e índice de variação genética para todos os caracteres, por ciclo de maturação e em forma global. Para isso foram utilizadas as análises de variância com suas respectivas esperanças de 
quadrados médios (método dos momentos). As esperanças dos quadrados médios foram calculadas mediante a opção "random" do procedimento "GLM" do pacote computacional SAS.

A partir das análises individuais foram estimados parâmetros genéticos entre médias de progênies, por meio dos seguintes estimadores:

$$
\hat{\sigma}_{g}^{2}=\frac{Q M_{P}-Q M_{E}}{r}
$$

sendo: $\hat{\sigma}_{\mathrm{g}}^{2}$ : estimador da variância genorípica de progênies;

$\mathrm{QM}_{\mathrm{P}}$ : quadrado médio de progênies;

$\mathrm{QM}_{\mathrm{E}}$ : quadrado médio do erro;

$r$ : número de repetições.

$$
h^{2}=\frac{Q M_{P}-Q M_{E}}{Q M_{P}} \times 100
$$

sendo:

$\mathrm{h}^{2}:$ herdabilidade

$$
C V_{g}=\frac{\sqrt{\hat{\sigma}_{g}^{2}}}{m} \times 100
$$

sendo:

$\mathrm{CV}_{\mathrm{g}}$ : coeficiente de variação genética;

m : média geral do caráter. 


$$
b=\frac{C V_{g}}{C V_{e}}
$$

sendo:

b : índice de variação genética;

$\mathrm{CV}_{\mathrm{e}}$ : coeficiente de variação experimental.

A partir das análises conjuntas foram estimados parâmetros genéticos entre médias de progênies por meio dos seguintes estimadores:

$$
\hat{\sigma}_{g}^{2}=\frac{Q M_{P}-Q M_{L x P}}{r l}
$$

sendo:

$\hat{\sigma}_{g}^{2}$ : estimador da variância genótipica de progênies;

$\mathrm{QM}_{\mathrm{LxP}}$ : quadrado médio da interação locais x progênies;

$l:$ número de locais;

r : número de repetições.

$$
\hat{\sigma}_{L x P}^{2}=\frac{Q M_{L x P}-Q M_{E}}{r}
$$

sendo:

$\hat{\sigma}_{\text {LxP }}^{2}$ : estimador da variância da interação locais x progênies.

$$
h_{c}^{2}=\frac{Q M_{P}-Q M_{L x P}}{Q M_{P}} \times 100
$$

sendo:

$\mathrm{h}_{\mathrm{c}}^{2}$ : herdabilidade da análise conjunta. 
Os parâmetros $\mathrm{CV}_{\mathrm{g}} \mathrm{e} \mathrm{b}$ foram obtidos da mesma forma que nas análises individuais.

Para entender melhor a natureza da interação locais $\mathbf{x}$ progênies foi feita a decomposição do quadrado médio da interação utilizando-se a expressão:

$$
Q M_{L x P}=\left(\frac{1}{2}\right)\left(\sqrt{Q M P_{1}}-\sqrt{Q M P_{2}}\right)^{2}+\left(1-r_{12}\right) \sqrt{Q M P_{1} \cdot Q M P_{2}}
$$

(Cockerham, 1963).

sendo:

$\mathrm{QM}_{\mathrm{LXP}}$ : quadrado médio da interação locais x progênies;

$\mathrm{QMP}_{1}$ e $\mathrm{QMP}_{2}$ : quadrados médios referentes as progênies nos locais 1 e 2, respectivamente;

$\mathrm{r}_{12}$ : correlação entre as médias (ajustadas) das progênies de um local para outro.

\subsubsection{Ganhos genéticos esperados e observados com a seleção}

Em cada geração, para cada ciclo de maturação e de forma geral, foi estimado o ganho genético esperado com a seleção para o caráter PG, simulando as seguintes alternativas: dentro de cada local separadamente (seleção específica); seleção num dado local e verificação do ganho esperado no outro (seleção indireta no local 1 e resposta esperada no local 2; no local 2 e resposta esperada no local 1); seleção baseada na média das progênies reunindo os dois locais (seleção geral ou marginal, com verificação dos ganhos esperados em cada local separadamente e no conjunto dos dois 
locais), conforme exposto por Vencovsky \& Barriga (1992). Para cada caso, os ganhos foram calculados com base no diferencial de seleção (ds) e levando-se em conta que no melhoramento de progênies avançadas em plantas autógamas explora-se toda a variância genética (Cockerham, 1963; Souza Jr., 1989).

i) Ganho esperado no local 1 (Areão):

$$
\mathrm{Gs}_{1}=\mathrm{ds}_{1} \cdot \mathrm{h}_{1}^{2}
$$

em que:

$\mathrm{Gs}_{1}$ : ganho genético esperado no local 1 ;

$\mathrm{ds}_{1}$ : diferencial de seleção no local 1;

$\mathrm{h}_{1}^{2}$ : herdabilidade no local 1 .

ii) Ganho esperado no local 2 (Anhembi):

$$
\mathrm{Gs}_{2}=\mathrm{ds}_{2} \cdot \mathrm{h}_{2}^{2}
$$

em que:

$\mathrm{Gs}_{2}$ : ganho genético esperado no local 2;

$\mathrm{ds}_{2}$ : diferencial de seleção no local 2;

$\mathrm{h}_{2}^{2}$ : herdabilidade no local 2 . 
iii) Seleção indireta:

- Seleção no local 1 e resposta esperada no local 2.

Para isso, identificaram-se no local 1 (Areão), as progênies julgadas superiores e procurou-se essas mesmas progênies no local 2 (Anhembi) para estimar o ganho indireto após calcular a média dessas progênies:

$$
\mathrm{Gs}_{2,1}=d s_{2,1} \cdot h^{2}
$$

em que:

$\mathrm{Gs}_{2,1}$ : ganho genético esperado no local 2, selecionando-se no local 1;

$\mathrm{ds}_{2,1}$ : diferencial de seleção no local 2 , selecionando-se no local 1.

- Seleção no local 2 e resposta esperada no local 1.

Para isso, identificaram-se no local 2, as progênies julgadas superiores e procurou-se essas mesmas progênies no local 1 para estimar o ganho indireto após calcular a média dessas progênies:

$$
\mathrm{Gs}_{1,2}=\mathrm{ds}_{1,2} \cdot \mathrm{h}_{1}
$$

em que:

$\mathrm{Gs}_{1,2}$ : ganho genético esperado no local 1 , selecionando-se no local 2;

$\mathrm{ds}_{1,2}$ : diferencial de seleção no local 1 , selecionando-se no local 2. 
iv) Seleção geral, baseada na média das progênies nos dois locais.

O critério de seleção, neste caso, foi a média das progênies, reunindo os dois locais.

- efeito sobre o conjunto dos dois locais:

$$
G s_{c}=d s_{c} \cdot h_{c}^{2}
$$

em que:

$\mathrm{Gs}_{\mathrm{c}}$ : ganhho genético esperado no conjunto dos dois locais;

$\mathrm{ds}_{\mathrm{c}}$ : diferencial de seleção no conjunto dos dois locais;

$\mathrm{h}_{\mathrm{c}}^{2}$ : herdabilidade a partir da análise conjunta dos dois locais.

- efeito sobre o ganho nos locais 1 e 2 :

Foram identificadas as melhores progênies, baseando-se nas médias gerais delas e identificou-se essas progênies nos locais 1 e 2, obtendo-se a média e o ganho genético em cada local:

$$
\mathrm{Gs}_{1,12}=\mathrm{ds}_{1,12} \cdot \mathrm{h}_{1}^{2}
$$

em que:

$\mathrm{Gs}_{1,12}$ : ganho genético esperado no local 1 , selecionando-se com base na média gerai;

$\mathrm{ds}_{1,12}$ : diferencial de seleção no local 1 , selecionando-se com base na média geral. 


$$
\mathrm{Gs}_{2,12}=\mathrm{ds}_{2,12} \cdot \mathrm{h}_{2}^{2}
$$

em que:

$\mathrm{Gs}_{2,12}$ : ganho genético esperado no local 2, selecionando-se com base na média geral;

$\mathrm{ds}_{2,12}$ : diferencial de seleção no local 2 , selecionando-se com base na média geral.

Devido ao fato da geração $F_{6: 3}$ ter sido semeada na época de outono/inverno e a geração $F_{7: 3}$ na época de verão, os ganhos esperados e observados na $F_{6: 3}$ foram calculados através de duas metodologias: a) com base na média da população sem seleção, confundindo-se os efeitos genéticos e de épocas; b) com base na média das testemunhas (tratamentos comuns nas duas épocas de semeadura), utilizadas para medir o efeito ambiental (épocas), permitindo estimar o efeito genético e, assim, obter maior precisão no cálculo do ganho genético observado; esta metodologia foi utilizada por Hill (1972), para calcular o ganho genético observado:

$$
G_{o}=\left(S_{\varepsilon}-C_{\imath}\right)-\left(S_{o}-C_{0}\right)
$$

onde:

$S_{\mathrm{t}}$ e $\mathrm{S}_{\mathrm{o}}$ : médias da população selecionada e da população básica sem seleção, respectivamente;

$\mathrm{C}_{\mathrm{t}}$ e $\mathrm{C}_{\mathrm{o}}$ : médias da população controle (testemunhas comuns) na última geração e na geração em que foi avaliada a população básica, respectivamente. 
Os ganhos genéticos observados na geração $F_{6: 3}$ foram calculados com base na média das progênies, reunindo-se os dois locais, pois foi dessa forma que se praticou a seleção.

$O$ ganho genético esperado na geração $F_{7: 3}$ foi calculado utilizando apenas a média da população básica sem seleção.

\subsubsection{Correlações fenotípicas, genotípicas e ambientais}

Nas duas gerações foram calculadas as correlações fenotípicas $\left(r_{f}\right)$, genotípicas $\left(r_{g}\right)$ e ambientais $\left(r_{e}\right)$, entre pares de caracteres e ao nível de médias de progênies, em cada local e para os dois locais combinados, utilizando-se as análises de variâncias e covariâncias, segundo Kempthorne (1973):

- Correlação fenotípica $\left(r_{F}\right)$

$$
r_{F}=\frac{\operatorname{CoV}_{\bar{P}(x, y)}}{\left[\hat{\sigma}_{F(x)}^{2} \cdot \hat{\sigma}_{F(y)}^{2}\right]^{1 / 2}}
$$

sendo:

$\operatorname{CoV}_{\mathrm{F}(\mathrm{x}, \mathrm{y})}$ : Estimador da covariância fenotípica entre os caracteres $\mathrm{x}$ e $\mathrm{y}$; $\hat{\sigma}_{\overline{\mathrm{P}}(\mathrm{x})}^{2}$ e $\hat{\sigma}_{\overline{\mathrm{F}}(\mathrm{y})}^{2}$ : Estimadores das variâncias fenotípicas para os caracteres $\mathrm{x}$ e y. 
- Correlação genotípica $\left(r_{g}\right)$

$$
r_{g}=\frac{\operatorname{CoV}_{g(x, y)}}{\left[\hat{\sigma}_{g(x)}^{2} \cdot \hat{\sigma}_{g(y)}^{2}\right]^{1 / 2}}
$$

sendo:

$\operatorname{CoV}_{g(x, y)}$ : Estimador da covariância genotípica entre os caracteres $\mathrm{x} \mathrm{e} \mathrm{y;}$

$\hat{\sigma}_{g(x)}^{2}$ e $\hat{\sigma}_{g(y)}^{2}$ : Estimadores das variâncias genotípicas para os caracteres x e y;

- Correlação ambiental $\left(r_{e}\right)$

$$
r_{e}=\frac{\operatorname{CoV}_{e(x, y)}}{\left[\hat{\sigma}_{e(x)}^{2} \cdot \hat{\sigma}_{e(y)}^{2}\right]^{1 / 2}}
$$

sendo:

$\operatorname{CoV}_{\mathrm{e}(\mathrm{x}, \mathrm{y})}$ : Estimador da covariância ambiental entre os caracteres $\mathrm{x}$ e y;

$\hat{\sigma}_{e(x)}^{2}$ e $\hat{\sigma}_{e(y)}^{2}$ : Estimadores da variância ambiental para os caracteres x e y;

\subsubsection{Análise de variância e parâmetros genéticos reunindo as gerações $F_{6: 3}$ e $F_{7: 3}$}

Utilizando-se as médias ajustadas ao nível de parcela, em cada local e em cada época de semeadura, foi realizada uma análise conjunta com as 210 progênies 
selecionadas em $\mathrm{F}_{6: 3}$, para cada ciclo de maturação e em forma geral. $\mathrm{O}$ esquema da análise de variância é apresentado na Tabela 5 .

Os efeitos de locais, repetições e progênies foram considerados aleatórios embora tenha sido feita seleção na $\mathrm{F}_{6: 3}$; o efeito de épocas foi considerado fixo. A partir da análise de variância e utilizando-se as esperanças dos quadrados médios, para esse modelo misto, foram obtidos os parâmetros genéticos entre médias de progênies, utilizando oș seguintes estimadores:

$$
\hat{\sigma}_{\mathrm{e}}^{2}=\mathrm{QM}_{\mathrm{B}}
$$

sendo:

$\hat{\sigma}_{\mathrm{E}}^{2}$ : Estimador da variância ambiental;

$\mathrm{QM}_{\mathrm{E}}$ : Quadrado médio do erro médio conjunto geral $\left(\mathrm{QM}_{26}\right.$ da Tabela 5).

$$
\hat{\sigma}_{g l a}^{2}=\frac{Q M_{g l a}-Q M_{E}}{(a / a-1) r}
$$

sendo:

$\hat{\sigma}_{\text {gla }}^{2}$ : Estimador da variância da tripla interação progênies x locais x épocas;

$\mathrm{QM}_{\mathrm{gla}}$ : Quadrado médio da tripla interação;

$\mathrm{r}$ : número de repetições.

$\mathrm{a}:$ número de épocas

$$
\hat{\sigma}_{g a}^{2}=\frac{Q M_{g a}-Q M_{g l a}}{(a / a-1) r l}
$$

sendo:

$\hat{\sigma}_{\mathrm{ga}}^{2}$ : Estimador da variância da interação progênies $\mathrm{x}$ épocas; 
$\mathrm{QM}_{\mathrm{ga}}$ : Quadrado médio da interação progênies $\mathrm{x}$ épocas;

$1:$ número de locais.

$$
\hat{\sigma}_{g l}^{2}=\frac{Q M_{g l}-Q M_{E}}{r a}
$$

sendo:

$\hat{\sigma}_{\mathrm{gl}}^{2}$ : Estimador da variância da interação progênies $\mathrm{x}$ locais;

$\mathrm{QM}_{\mathrm{gl}}$ : Quadrado médio da interação progênies $\mathrm{x}$ locais;

$$
\hat{\sigma}_{g}^{2}=\frac{Q M_{p}-\sigma_{e}^{2}-r a \sigma_{g l}^{2}}{r l a}
$$

sendo:

$\hat{\sigma}_{\mathrm{g}}^{2}$ : Estimador da variância genotípica de progênies;

$\mathrm{QM}_{\mathrm{p}}$ : Quadrado médio de progênies.

$$
\hat{\sigma}_{F}^{2}=\hat{\sigma}_{g}^{2}+\frac{\hat{\sigma}_{g a}^{2}}{A}+\frac{\hat{\sigma}_{g l}^{2}}{L}+\frac{\hat{\sigma}_{g l a}^{2}}{L A}+\frac{\hat{\sigma}_{e}^{2}}{R L A}
$$

sendo:

$\hat{\sigma}_{\mathrm{P}}^{2}$ : Variância fenotípica total entre as médias das progênies, quando comparadas em R : Repetições; L : Locais e A : Épocas.

$$
\bar{h}^{2}=\frac{\hat{\sigma}_{g}^{2}}{\hat{\sigma}_{F}^{2}}
$$

sendo:

$h^{2}:$ herdabilidade entre médias de progênies. 


\section{RESULTADOS E DISCUSSÃO}

\subsection{Geração $F_{6: 3}$}

\subsubsection{Análises individuais de variância}

Nas Tabelas 6 e 7 são apresentados os valores e significâncias dos quadrados médios, médias ajustadas de progênies e testemunhas, coeficiente de variação experimental e coeficiente de determinação obtidos nas análises individuais para os locais Areão e Anhembi, para os caracteres número de dias para a maturidade (NDM), altura da planta na maturidade (APM), valor agronômico (VA), produtividade de grãos (PG), porcentagem de óleo na semente (\%OL) e produtividade de óleo (PO).

Os coeficientes de variação experimental (CVe) variaram de 4,4\% (\%OL) até 35,6\% (PO) no local Areão e de 2,5\% (NDM) até 36,1\% (PO) no local Anhembi. Os altos CVe's obtidos para os caracteres PG e PO, nos dois locais, podem ser explicados pelo grande número de progênies. Os coeficientes de determinação $\left(R^{2}\right)$ que indicam o grau de ajuste do modelo utilizado na análise dos dados experimentais variaram de $0,62(\% \mathrm{OL})$ até $0,88(\mathrm{APM})$ no local Areão e de $0,62 \%$ (\%OL) até 0,84 
(APM e VA) no local Anhembi, indicando que o modelo utilizado ajustou-se de maneira aceitável. Deve ser lembrado que a análise em cada local foi realizada como blocos casualizados, utilizando-se as médias ajustadas por parcela, após a análise como blocos aumentados para as duas repetições.

No local Areão os dados apresentaram diferenças significativas entre os ciclos de maturidade, tipos de cadeia e cruzamentos, para todos os caracteres. Para progênies foram detectadas diferenças para todos os caracteres, exceto \% OL.

O desdobramento dos quadrados médios de progênies em precoces, intermediárias e tardias, mostrou que nas progênies precoces o único caráter que não apresentou diferença significativa foi NDM; já nas intermediárias e tardias, o único caráter para o qual não se encontrou diferença significativa foi \%OL.

No local Anhembi foram encontradas diferenças para todos os caracteres entre ciclos de maturidade, tipos de cadeia e cruzamentos. Entre progênies, o único caráter que não apresentou diferença significativa foi \%OL, como ocorrido para o local Areão. $\mathrm{O}$ desdobramento do quadrado médio de progênies em precoces, intermediárias e tardias, mostrou os mesmos resultados do local Areão, à exceção de que as progênies intermediárias não apresentaram diferenças para o caráter NDM, enquanto as precoces sim.

A não significância para o caráter NDM nas progênies precoces, no local Areão, e das intermediárias, no local Anhembi, indica que essas progênies foram bem classificadas de acordo com seu ciclo de maturidade. 
Os resultados nos dois locais indicam ampla variação genética entre as progênies para os caracteres APM, VA, PG e PO. Todavia, para o caráter \%OL só se observa variação entre as progênies precoces. A variabilidade genética no caráter APM sugere a presença e a possibilidade de se selecionar genótipos com florescimento tardio em dias curtos (periodo juvenil longo), já que a geração $\mathrm{F}_{6: 3}$ foi semeada na época de outono/inverno; para tanto, deve-se tomar valores altos de APM como indicadores de florescimento tardio em dias curtos, como apontado por Miranda et al. (1990).

As médias gerais das progênies foram similares às médias das testemunhas. No local Areão, as testemunhas foram superiores em APM e VA, mas para os caracteres NDM, PG, OL e PO, suas médias foram inferiores. No local Anhembi, as testemunhas mostraram valores mais altos para os caracteres APM, VA, PG e PO, mas as diferenças foram significativas só em APM e VA.

\subsubsection{Análise conjunta de variância}

A análise conjunta de variância na geração $\mathrm{F}_{6: 3}$ encontra-se na Tabela 8. Foram detectadas diferenças entre os locais, para todos os caracteres avaliados. Entre progênies, os resultados mostram que igualmente às análises individuais, o único caráter em que não se encontrou diferença significativa foi \%OL. $\mathrm{O}$ desdobramento do quadrado médio das progênies em precoces, intermediárias e tardias mostrou resultados similares, exceto que nas precoces, o caráter \%OL apresentou diferenças significativas. 
O estudo da interação $\mathrm{G} \times \mathrm{E}$ através da análise conjunta mostrou que os ciclos de maturidade, tipos de cadeia e cruzamentos apresentaram interação com locais em todos os caracteres, com exceção de APM para ciclos de maturidade e VA para tipos de cadeia de cruzamentos. Entre progênies, evidenciou-se interação $G \times E$ para os caracteres NDM, PG e PO, sendo que as progênies precoces apresentaram interação com locais para PG, \%OL e PO; as intermediárias para NDM, PG e PO; e as tardias mostraram interação significativa para os caracteres NDM, APM, PG e PO.

Portanto, os resultados indicam que para os caracteres PG e PO, a presença da interação $\mathrm{G} \times \mathrm{E}$ é comum em todos os tipos de progênies (precoces, intermediárias e tardias), sendo que para os caracteres NDM, APM e \%OL existem resultados diferentes para cada ciclo de maturidade.

A presença da interação locais $x$ progênies, de maneira geral e em cada ciclo de maturidade, para os caracteres PG e PO, indica a existência de um comportamento diferencial das progênies nos ambientes avaliados e sugere a necessidade de se selecionar genótipos específicos para cada local ou identificar e selecionar àqueles que não apresentam variação através dos locais (Cruz \& Regazzi, 1994). 


\subsection{Geração $F_{7: 3}$}

\subsubsection{Análises individuais de variância}

Os valores e significâncias dos quadrados médios, médias ajustadas de progênies e testemunhas, coeficientes de variação experimental e coeficientes de determinação obtidos nas análises de variância, para os locais Areão e Anhembi, na geração $F_{7: 3}$, para os mesmos caracteres avaliados na geração anterior, são apresentados nas Tabelas 9 e 10.

Os coeficientes de variação experimental (CVe) variaram de 2,0\% (NDM) até 32,6\% (PO), em Areão, e de 1,6\% (NDM) até 18,6\% (PG e PO), em Anhembi. Esses valores de CVe indicam melhor precisão experimental no local Anhembi. Assim também, os CVe's obtidos são menores do que aqueles da geração $F_{6: 3}$ e são semelhantes aos obtidos por Zimback (1992), Montaño-Velasco (1994) e Farias Neto (1995), que avaliaram as gerações $F_{2}$ a $F_{5}$ dos materiais utilizados neste estudo. De maneira geral, os coeficientes de determinação $\left(\mathbf{R}^{2}\right)$ foram maiores em Anhembi, mostrando um melhor ajuste do modelo utilizado na análise dos dados experimentais, neste local.

As análises de variância tanto em Areão quanto em Anhembi mostram diferenças não significativas entre experimentos, para todos os caracteres. Isto justifica a análise conjunta dos quatro experimentos (dois experimentos com progênies precoces, 
um com intermediárias e um com tardias), como blocos incompletos segundo Pimentel Gomes (1990). Outro fato que viabiliza a análise conjunta desses experimentos é a diferença não significativa da interação experimentos $\mathrm{x}$ testemunhas, nos dois locais, para todos os caracteres, exceto NDM em Areão. Isso indica que os tratamentos comuns (testemunhas) comportaram-se semelhantemente em todos os experimentos, o que sugere efeitos ambientais semelhantes para os tratamentos regulares (progênies), mesmo localizados em experimentos diferentes.

No local Areão (Tabela 9), a análise de variância indicou que, entre os tratamentos houve diferenças significativas para todos os caracteres. O desdobramento do quadrado médio de tratamentos mostrou o seguinte: entre ciclos de maturidade foram detectadas diferenças para NDM, APM, PG e PO; entre tipos de cadeia de cruzamentos para todos os caracteres; entre cruzamentos houve diferenças nos caracteres NDM, APM, VA, PG e PO. As progênies, de maneira geral, apresentaram diferenças para NDM, APM, VA, PG e PO e, do mesmo modo que na geração $F_{6: 3}$, não foi detectada diferença para o caráter \%OL. As testemunhas apresentaram diferenças para NDM, APM, PG, \%OL e PO; e, a comparação entre testemunhas e progênies, apresentou diferenças significativas para NDM, \%OL e PO.

A Tabela 9 também mostra que em Areão, o desdobramento do quadrado médio de progênies em precoces, intermediárias e tardias evidenciou diferenças entre as progênies precoces para todos os caracteres. As progênies intermediárias e tardias não apresentaram diferenças para o caráter APM nas intermediárias e NDM nas tardias. 
No local Anhembi (Tabela 10), a análise de variância mostrou que da mesma forma que em Areão, os tratamentos apresentaram diferenças para todos os caracteres e o desdobramento do seu quadrado médio indicou o seguinte: para os ciclos de maturidade, existiu diferenças nos caracteres NDM, APM, VA, PG e PO; foram detectadas diferenças entre os tipos de cadeia e entre os cruzamentos para todos os caracteres. As progênies apresentaram diferenças significativas para todos os caracteres, ocorrendo o mesmo entre as testemunhas. A comparação entre progênies e testemunhas evidenciou diferença unicamente para o caráter \%OL.

Ainda de acordo com a Tabela 10, em Anhembi, o desdobramento do quadrado médio de progênies em precoces, intermediárias e tardias, mostrou que entre progênies precoces houve diferenças para todos os caracteres. As intermediárias apresentaram diferenças para NDM, APM, VA, PG e PO. As progênies tardias apresentaram diferenças para NDM, APM, PG e PO.

Os resultados mostram que, apesar da seleção praticada na geração $F_{6: 3}$, ainda existe variação genética entre as progênies para todos os caracteres, exceto para o caráter \%OL, que apresentou variação somente entre progênies precoces. No local Areão, não foi detectada variação entre as progênies intermediárias e nem entre as tardias; isso ocorreu provavelmente porque a precisão experimental foi menor neste local ou por algum efeito ambiental. 


\subsubsection{Análise conjunta de variância}

A análise conjunta de variância da geração $\mathrm{F}_{7: 3}$ encontra-se na Tabela 11. Houve diferenças significativas entre locais unicamente para os caracteres PG e PO. Entre ciclos de maturidade, não houve diferença significativa para nenhum caráter. Entre os tipos de cadeia, existiram diferenças significativas apenas para APM, VA e PO. Os cruzamentos apresentaram diferenças para todos os caracteres. Entre progênies, encontrou-se diferenças para os caracteres NDM, APM, VA; \%OL e PG. As progênies precoces apresentaram diferenças para todos os caracteres. As progênies intermediárias não apresentaram diferenças para nenhum caráter e as tardias, unicamente para os caracteres NDM e \%OL.

No estudo da interação $\mathrm{G} \times \mathrm{E}$, os ciclos de maturidade apresentaram interação com locais para todos os caracteres, exceto \%OL. Os tipos de cadeia interagiram com locais para NDM, APM, PG e \%OL. Os cruzamentos apresentaram interação significativa para todos os caracteres, exceto VA. As progênies apresentaram interação com locais unicamente para os caracteres PG e PO.

As progênies precoces apresentaram interação unicamente nos caracteres PG e PO, as intermediárias não apresentaram interação significativa para nenhum caráter e as tardias tiveram interação com locais nos caracteres NDM, PG e PO. Os resultados indicam comportamento diferente dentro de cada ciclo de maturação e entre locais. Igualmente à geração $F_{6: 3}$, na geração $F_{7: 3}$ os caracteres $P G$ e PO mostraram significância da interação $\mathrm{G} \times \mathrm{E}$ para os ciclos precoces e tardios. 


\subsection{Avaliação geral das progênies $F_{6: 3}$ e $F_{7: 3}$}

A análise geral das progênies $F_{6: 3}$ e $F_{7: 3}$ dentro dos cruzamentos, está compreendida nas Tabelas 12 a 17, nas quais são apresentadas as estimativas de médias ajustadas, variâncias fenotípicas e intervalo de variação para os caracteres número de dias para a maturidade (NDM), altura da planta na maturidade (APM), valor agronômico (VA), produtividade de grãos (PG), porcentagem de óleo (\%OL) e produtividade de óleo (PO), nos locais Areão e Anhembi para as duas gerações.

A análise geral do comportamento das progênies nos dois locais e nas duas gerações, indica que no local Anhembi as progênies apresentaram melhor média e maior variância para todos os caracteres. Essa diferença entre os locais deveu-se talvez às diferenças das propriedades químicas dos solos onde a pesquisa foi realizada (Apêndice 5b). Embora as análises de solo tenham sido feitas após a realização dos experimentos deste estudo, os resultados apresentados no Apêndice $5 \mathrm{~b}$ mostram que a área do local Areão apresenta alta acidez, com teores médios de matéria orgânica (MO), baixos teores de fósforo $(\mathrm{P})$ (em resina), altos teores de cálcio $(\mathrm{Ca})$ mais magnésio $(\mathrm{Mg})$ e média saturação de bases (\% V). Entretanto, a área do local Anhembi apresenta acidez muito baixa, com teores médios de MO, suficientes teores de $\mathrm{P}$ (em resina), altos teores de Ca mais $\mathrm{Mg}$ e alta saturação de bases. Seguindo os critérios para interpretação de análises de solos para o Estado de São Paulo, apresentados por Malavolta et al. (1989) no Apêndice 5a, pode-se concluir que a área do local Anhembi apresenta as melhores condições para a cultura da soja. 


\subsubsection{Número de dias para a maturidade e altura da planta na maturidade}

Nas Tabelas 12 e 13 são apresentadas as estimativas de médias ajustadas, variâncias fenotípicas e intervalo de variação dos caracteres número de dias para a maturidade (NDM) e altura da planta na maturidade (APM) para os 40 cruzamentos e as quatro testemunhas, nas duas gerações e nos dois locais.

De maneira geral, a geração $F_{6: 3}$ foi em média, 21 dias mais precoce do que a geração $F_{7: 3}$, devido principalmente à sua semeadura ter ocorrido na época de outono/inverno. Os cruzamentos mais precoces na geração $F_{6: 3}$ no local Areão, foram N82-2764-S x SOC 81-127-S (7x8) e FT8 x OC 79-7 (30x31) com 108 dias e, no local Anhembi, o cruzamento mais precoce foi UFV-4 x BR 80-16309 (38x39) com 110 dias. Os cruzamentos precoces e comuns aos locais, foram: FT8 x OC 79-7 (30x31) com 108 e 111 dias, respectivamente em Areão e Anhembi; Paraná-s x Kirby (4x5) com 110 e 112 dias; Bienville x UFV-Araguaia (21x22) com 110 e 111 dias. Todos esses cruzamentos, também foram mais precoces nas gerações $F_{4}$ e $F_{5}$ (Farias Neto, 1995). O cruzamento mais tardio tanto no local Areão quanto em Anhembi foi AX 5355-s x Paranagoiana (13x14) com 131 e 122 dias, respectivamente, seguido pelo cruzamento BR-9 x EMGOPA-301 (32×33).

Na geração $\mathrm{F}_{7: 3}$ os cruzamentos mais precoces, em média, através dos dois locais foram: FT 79-3408 x AX 5355-s (12x13) com 128 e 133 dias, SOC 81-127-s x Wright (8x9) com 129 e 130 dias e GO 81-11094 x BR-11 (28x29) com 129 e 130 
dias. Entretanto, o cruzamento mais tardio e nos dois locais foi BR-9 x EMGOPA-301 (32x33) com 144 e 145 dias, respectivamente. Outros cruzamentos tardios e comuns aos dois locais foram: EMGOPA-301 x IAC-9 (33x34), AX 5355-s x Paranagoiana (13x14), BR 80-16309 x UFV-1 (39x40), UFV-Araguaia x Bossier (22x23), todos eles confirmados por Farias Neto (1995) como os mais tardios. Zimback (1992) e MontañoVelasco (1994) também observaram que o cruzamento EMGOPA-301 X IAC-9 foi o mais tardio nas gerações $F_{2}$ e $F_{3}$ destes mesmos materiais estudados.

Os dados de altura da planta na maturidade (Tabela 13) mostram que, em geral, nas duas gerações, os cruzamentos apresentaram maior altura, no local Anhembi (diferenças de $7 \mathrm{~cm}$ e $2 \mathrm{~cm}$, nas gerações $F_{6: 3}$ e $F_{7: 3}$, respectivamente). A geração $F_{7: 3}$ teve, em média, $23 \mathrm{~cm}$ mais que a geração $\mathrm{F}_{6: 3}$. Isso pode ser explicado como sendo um efeito da época de semeadura e da seleção praticada em $\mathrm{F}_{6: 3}$. Separando o efeito de épocas através das testemunhas, a seleção foi responsável por $13 \mathrm{~cm}$.

Na geração $F_{6: 3}$, o cruzamento mais baixo nos dois locais foi N82-2764-s x SOC 81-127-s (7x8) com $31 \mathrm{~cm}$ em Areão e $39 \mathrm{~cm}$ em Anhembi, sendo que 33 cruzamentos em Areão e 33 cruzamentos em Anhembi não alcançaram a média mínima de altura de $60 \mathrm{~cm}$.

Os cruzamentos que se sobressaíram, pela média e a variância na geração $\mathrm{F}_{6: 3}$ para os caracteres NDM e APM, mostrando que nesses cruzamentos existem genótipos com genes para florescimento tardio em dias curtos (período juvenil longo), foram: 
IAC-9 x GO 79-1030

IAC- $6 \times$ UFV-4

AX 5255-s x Paragoiana

Cristalina $x$ IAC-6

BR-9 x EMGOPA-301

EMGOPA-301 $\times$ IAC-9

OC 79-7 x BR-9

Paranagoiana $\mathrm{x}$ Jackson 4028-s (34x35), (37x38), (13x14), (36x37), (32×33), (33×34), $(31 \times 32)$ e (14x15).

Por outro lado, a Tabela 13 mostra que quase todos os cruzamentos apresentaram genótipos com florescimento tardio em dias curtos, sendo que cinco cruzamentos não apresentaram genótipos com essa característica.

Na geração $F_{7: 3}$, os cruzamentos de menor altura em média através dos dois locais foram: Wright x SOC 81-76 (9x10) com 55 e $45 \mathrm{~cm}$ no Areão e Anhembi, respectivamente, e FT-2 x N 82-2764-s $(6 \times 7)$ com 59 e $58 \mathrm{~cm}$, sendo que cinco cruzamentos no Areão e oito no Anhembi não alcançaram a média de $60 \mathrm{~cm}$.

$\mathrm{Na}$ geração $\mathrm{F}_{7: 3}$ sobressairam-se, por terem maior altura das plantas, os seguintes cruzamentos:

$\begin{array}{ll}\text { GO 81-8491 x BR 80-15725-B-S } & (25 \times 26), \\ \text { Planalto-s x GO 81-11094 } & (27 \times 28), \\ \text { Bossier-s x UFV-2 } & (23 \times 24), \\ \text { OC 79-7 x BR-9 } & (31 \times 32), \\ \text { IAC-6 x UFV-4 } & (37 \times 38), \\ \text { Cristalina x IAC-6 } & (36 \times 37), \\ \text { EMGOPA-301 x IAC-9 } & (33 \times 34), \\ \text { AX 5355-s x Paranagoiana } & (13 \times 14) \mathrm{e} \\ \text { BR-9 x EMGOPA-301 } & (32 \times 33) .\end{array}$


Neste grupo, os últimos três cruzamentos também estiveram entre os mais altos na geração $\mathrm{F}_{6: 3}$.

\subsubsection{Valor agronômico e produtividade de grãos}

Os valores de médias ajustadas, variância fenotípica e intervalo de variação para os caracteres valor agronômico (VA) e produtividade de grãos (PG), para os 40 cruzamentos e as quatro testemunhas, nas duas gerações e nos dois locais, estão apresentados nas Tabelas 14 e 15.

Na geração $F_{6: 3}$, o cruzamento que apresentou menor VA foi Cobb x BR8 (17x18) com notas de 1,2 e 1,7 em Areão e Anhembi, respectivamente, seguido por N 82-27645-s x SOC 81-127-s (7x8), BR-8 x PI 200521 (18x19) e Bienville x UFVAraguaia (21×22). Já os cruzamentos de maior média e nos dois locais, foram os seguintes:

$\begin{array}{ll}\text { Cristalina-s x IAC-6 } & (36 \times 37), \\ \text { BR-9 x EMGOPA-301 } & (32 \times 33), \\ \text { EMGOPA-301 x IAC-9 } & (33 \times 34), \\ \text { OC 79-7 x BR-9 } & (31 \times 32), \\ \text { Paranagoiana x Jackson 4028-s } & (14 \times 15) \text { e } \\ \text { IAC-9 x GO 79-1030 } & (34 \times 35) .\end{array}$

Todos estes, exceto Paranagoiana x Jackson 4028-s pertecem à cadeia adaptada de cruzamentos e de parentais com genes para florescimento tardio em dias curtos. 
Na geração $F_{7: 3}$, os cruzamentos que tiveram, em média (através de dois locais), menor VA foram: SOC 81-127-s x Wright (8x9) seguidos por Wright $\mathrm{x}$ SOC 81-76 (9x10) e BR 80-15725-B-s x Planalto-s (26x27). Já os que apresentaram em média uma nota superior a três, foram:

$\begin{array}{ll}\text { Jackson } 4028-s \times \text { FT } 81-2129 & (15 \times 16), \\ \text { GO } 81-8491 \times \text { BR 80-15725-B-s } & (25 \times 26), \\ \text { GO 79-1030 x Cristalina-s } & (35 \times 36), \\ \text { Bossier-s x UFV-2 } & (23 \times 24), \\ \text { Cristalina-s x IAC-6 } & (36 \times 37), \\ \text { EMGOPA-301 x IAC-9 } & (33 \times 34), \\ \text { IAC-9 x GO 79-1030 } & (34 \times 35) \mathrm{e} \\ \text { IAC-6 x UFV-4 } & (37 \times 38) .\end{array}$

Os quatro últimos apresentaram bons resultados nas duas gerações.

Os dados de produtividade de grãos (Tabela 15), mostram que nas duas gerações, a média das progênies no local Anhembi foi maior do que no local Areão (2,05 e 2,07 vezes maior nas gerações $F_{6: 3}$ e $F_{7: 3}$, respectivamente). Em termos relativos na geração $\mathrm{F}_{7: 3}$ houve uma produtividade de grãos de 1,19 t/ha a mais do que na geração $\mathrm{F}_{6: 3}$. Porém, essa diferença leva em consideração o efeito da seleção e de época de semeadura. $\mathrm{O}$ efeito de época pode ser obtido pela análise da média das testemunhas (comum nas duas gerações) e que mostra uma diferença de 1,0 t/ha de uma geração para outra, sugerindo que a diferença devido à seleção corresponderia, em média, à 0,19 t/ha, através dos dois locais. No entanto, obtendo-se a diferença por local pode-se observar que no Anhembi foi de 0,43 t/ha e no Areão apenas 0,06 t/ha. 
Na geração $\mathrm{F}_{6: 3}$ os cruzamentos com menor PG em média foram: FT-8 x OC 79-7 (30x31), Cobb x BR-8 (17x18), Bienville x UFV-Araguaia (21x22) e N-822764-s x SOC 81-127-s (7x8). Já os de maior produtividade foram:

$\begin{array}{ll}\text { EMGOPA-301 X IAC-9 } & (33 \times 34), \\ \text { Cristalina-s x IAC-6 } & (36 \times 37), \\ \text { FT 79-3408 x AX 5355-s } & (12 \times 13), \\ \text { BR-9 x EMGOPA-301 } & (32 \times 33), \\ \text { GO 81-8491 x BR 80-15725-B-s } & (25 \times 26), \\ \text { IAC-6 x UFV-4 } & (37 \times 38) \text { e } \\ \text { AX 5355-s x Paranagoiana } & (13 \times 14) .\end{array}$

Na geração $F_{7: 3}$, o cruzamento com menor PG, em média, foi Wright $x$ SOC $81-76(9 \times 10)$ seguido pelos cruzamentos FT $81-2706$ x PI $371.610(2 \times 3)$ e SOC 81-76 x Foster $(10 \times 11)$ todos pertencentes a cadeia mista. Os cruzamentos que sobressaíram, pela média geral e variância nesta geração, foram:

$\begin{array}{ll}\text { IAC-9 x GO 79-1030 } & (34 \times 35), \\ \text { GO } 79-1030 \times \text { Cristalina-s } & (35 \times 36), \\ \text { BR 80-16309 x UFV-1 } & (39 \times 40), \\ \text { FT 81-2129 x Cobb } & (16 \times 17), \\ \text { AX 5355-s x Paranagoiana } & (13 \times 14), \\ \text { GO 81-8491 x BR 80-15725-B-s } & (25 \times 26), \\ \text { IAC-6 x UFV-4 } & (37 \times 38), \\ \text { Bossier x UFV-2 } & (23 \times 24), \\ \text { BR-9 x EMGOPA-301 } & (32 \times 33), \\ \text { EMGOPA-801 x IAC-9 } & (33 \times 34) \text { e } \\ \text { OC 79-7 x BR-9 } & (31 \times 32) .\end{array}$


Todos, exceto $16 \times 17$ e $13 \times 14$, pertencem à cadeia adaptada, indicando que os parentais exóticos diminuem as chances de desenvolver progênies produtivas.

É preciso salientar que os cruzamentos de maior produtividade são os mesmos cruzamentos classificados como de maior altura e de maior valor agronômico. Isso resulta da alta correlação entre esses três caracteres (Tabela 29) e que possibilita a seleção simultânea para esses caracteres.

As testemunhas que tiveram maior produtividade de grãos foram as de ciclo tardio (UFV-4 e IAC Santa Maria 702).

\subsubsection{Teor e produtividade de óleo}

Os dados correspondentes às médias ajustadas, variação fenotípica e intervalo de variação para os caracteres porcentagem de óleo (\%OL) e produtividade de óleo (PO) para os 40 cruzamentos e as quatro testemunhas, nas duas gerações e nos dois locais, são apresentados nas Tabelas 16 e 17.

Para o caráter \%OL as diferenças entre locais e entre gerações foram pequenas. A geração $F_{6: 3}$ foi, em média, $0,77 \%$ superior à geração $F_{7: 3}$. Na geração $F_{6: 3}$, os cruzamentos com maior média geral $(22,8 \%$ e $23,2 \%)$, foram os seguintes:

BR-11 x FT-8

Planalto-s x GO 81-1 1094

Bossier-s x UFV-2

FT-8 $x$ OC 79-7
$(29 \times 30)$, (27×28), $(23 \times 24)$, $(30 \times 31)$, 


$\begin{array}{ll}\text { UFV-2 x GO-81-8491 } & (24 \times 25), \\ \text { SOC } 81-76 \text { x Foster } & (10 \times 11), \\ \text { Bienville x UFV-Araguaia } & (21 \times 22), \\ \text { Andrews purpura x FT 81-2706 } & (1 \times 2) \text { e } \\ \text { GO 81-11094 x BR-11 } & (28 \times 29) .\end{array}$

Esses cruzamentos obtiveram dados similares à melhor testemunha, o cultivar UFV-4 $(23,0 \%)$, considerado de alto teor de óleo.

Na geração $F_{7: 3}$, os cruzamentos que se destacaram pela média geral neste caráter e que tiveram resultados similares à UFV-4, foram:

$\begin{array}{ll}\text { UFV-Araguaia x Bossier-s } & (22 \times 23), \\ \text { GO 79-1030 x Cristalina-s } & (35 \times 36), \\ \text { Planalto-s x GO 81-11094 } & (27 \times 28), \\ \text { IAC-9 x GO 79-1030 } & (34 \times 35) \text { e } \\ \text { BR 80-15715-B-s x Planalto-s } & (26 \times 27) .\end{array}$

Zimback (1992) indicou, já na geração $F_{2}$, que os cruzamentos envolvendo os parentais GO 81-8491, BR $80-15725$-B-s e Planalto-s tinham potencial para alta porcentagem de óleo. Farias Neto (1995) também constatou que a maior porcentagem de óleo foi obtida para o cruzamento BR 80-15725-B-s x Planalto-s.

O caráter $\mathrm{PO}$, por ser resultado do produto entre a produtividade de grãos e porcentagem de óleo (\%OL) e este último apresentar pouca variabilidade entre as progênies, depende mais do caráter PG. Pelo que o "ranking" dos cruzamentos segue a mesma ordem obtida para o caráter PG. 


\subsection{Componentes de variância e parâmetros genéticos}

As estimativas de médias ajustadas, variância genética $\left(\hat{\sigma}_{\mathrm{g}}^{2}\right)$, variância da interação progênies $x$ locais $\left(\hat{\sigma}_{\text {gxte }}^{2}\right)$, variância do erro $\left(\hat{\sigma}_{\mathrm{e}}^{2}\right)$, coeficiente de herdabilidade $\left(h^{2}\right)$, coeficiente de variacão genética $(\mathrm{CVg})$, coeficiente de variacão experimental $(\mathrm{CVe})$ e índice de variação genética (b) para todos os caracteres, nas duas geracões, de forma geral e para cada ciclo de maturidade, são apresentadas nas Tabelas 18 a 21 .

Nas duas gerações, as médias ajustadas para todos os caracteres foram superiores no local de Anhembi, com poucas exceções. As estimativas de herdabilidade estão compreendidas entre as obtidas pelos pesquisadores citados na literatura (Apêndice 1).

De maneira geral (Tabela 18) com exceção do caráter \%OL a variância genética para todos os caracteres foi menor na geracão $F_{7: 3}$ do que em $F_{6: 3}$, devido ao efeito da seleção praticada em $\mathrm{F}_{6: 3}$. É sabido que a seleção contínua favorece $o$ acúmulo de alelos favoráveis na populacão, no entanto, a variância genética decresce entre os ciclos de selecão (Smith \& Weber, 1968). Por outro lado, a variância ambiental foi maior na $\mathrm{F}_{7: 3}$, exceto para o caráter $\mathrm{NDM}$, o que pode explicar a diminuição dos coeficientes de herdabilidade na $F_{7: 3}$, a exceção dos caracteres NDM e \%OL. No entanto, a redução da variabilidade deve ser vista com cautela, porque sabe-se que em ambientes de dias curtos, a dispersão dos genótipos é maior, ocasionando uma maior variabilidade (Toledo et al., 1994). $O$ anterior ocorreu na geração $F_{6: 3}$ semeada na época de outono/inverno. 
As progênies apresentaram, em média, maior variação genética no local Anhembi do que no local Areão, nas duas gerações, novamente com exceção dos caracteres \%OL e NDM na $\mathrm{F}_{6: 3}$. Entretanto, a variância ambiental, em geral, foi maior no local Areão. Isso fez com que as herdabilidades tenham sido sempre maiores no local Anhembi, à exceção do caráter \%OL no Areão, acontecendo o mesmo com os coeficientes de variação genética.

Segundo Lal \& Haque (1972), o coeficiente de variação genética ajuda na obtenção da amplitude da diversidade genética num caráter e proporciona uma via para comparar a variabilidade genética nos caracteres quantitativos. Nesse sentido, podese observar (Tabela 18) que os maiores CVg's foram obtidos para os caracteres PG e PO, seguidos dos caracteres APM e VA.

O coeficiente de variação genética junto com o coeficiente de herdabilidade, proporcionam um melhor panorama da quantidade de ganho esperado pela seleção. Nesse aspecto, os dados da Tabela 18 permitem concluir que o local Anhembi se apresenta como o local onde obter-se-ia maior ganho genético na seleção das melhores progênies, isso para todos os caracteres e nas duas gerações.

O índice de variação genética (b) foi estabelecido por Vencovsky (1987) e quantifica a proporção da variabilidade genética em relação à variabilidade ambiental. Pode-se observar que os valores de b, obtidos nas duas gerações e para todos os caracteres, foram maiores no local Anhembi que no Areão. Quando o valor de b aproxima-se de 1, tem-se o indicativo de um ambiente favorável para seleção. 
Os resultados expostos anteriormente permitem sugerir que o local Anhembi foi superior, pois permitiu aos genótipos expressarem melhor seu potencial genético (maior média, principalmente no caráter PG e maior variação em todos os caracteres). Além disso, sugere-se que ambientes de alta produtividade são mais apropriados para selecionar genótipos superiores. Os ambientes de produtividades altas permitem maior discriminação entre os genótipos devido à maior variabilidade entre esses genótipos. Também, Allen et al. (1978) concluíram que ambientes favoráveis tendem a produzir variâncias genéticas maiores e grandes taxas de ganho genético.

A ampla variação entre os locais (Tabela 18), principalmente nos caracteres PG e PO, e a magnitude relativa da variância genética nas localidades, indicam a influência do ambiente no comportamento das progênies. $O$ fato das estimativas de herdabilidade no local Areão serem baixas, enfatiza que o comportamento das progênies nesse local foi, em grande parte, determinado pelas causas ambientais. As variações na magnitude da herdabilidade entre locais sugere que as progênies não reagiram da mesma forma nos ambientes avaliados, devido a interação $\mathrm{G} \times \mathrm{E}$, isso nas duas gerações (Dashiell et al., 1994).

Para as progênies de ciclo de maturação precoce (Tabela 19) as mesmas observações anteriores podem ser aplicadas. Porém, deve-se salientar que as variâncias genotípicas da geração $\mathrm{F}_{6: 3}$ foram mantidas na geração $\mathrm{F}_{7: 3}$, sendo que, para o caráter \%OL, esta aumentou em dobro. Absolutamente o contrário aconteceu com as progênies intermediárias e tardias (Tabelas 20 e 21), em que as variâncias genotípicas diminuíram 
de uma maneira drástica na geração $\mathrm{F}_{7: 3}$, obtendo-se, inclusive, variâncias genotípicas negativas e ocasionando coeficientes de herdabilidade de até zero, principalmente no local Areão. É importante ressaltar que as estimativas de variâncias têm que ser utilizadas com cautela, pois estas são sujeitas a erro.

Em relação ao tamanho relativo da variância genética por ciclo de maturidade na geração $\mathrm{F}_{6: 3}$, os genótipos tardios apresentaram maiores variâncias genéticas para os caracteres NDM, APM, PG e PO; já os precoces apresentaram a maior variância para os caracteres $\mathrm{VA}$ e \%OL. Na geração $\mathrm{F}_{7: 3}$, as progênies precoces tiveram a maior variância genética para todos os caracteres, exceto para NDM, que foi obtida pelas progênies tardias.

As estimativas dessas variâncias genéticas entre progênies, em cada ciclo de maturidade, devem ser analisadas com cautela, porque foi assumido que a variância ambiental foi a mesma para todos os genótipos e isso não é sempre verdadeiro. Segundo Falconer (1989), os genótipos podem ser mais ou menos sensíveis à influências ambientais e, portanto, podem mostrar maior ou menor variação ambiental.

No estudo da variância da interação observa-se que, de maneira geral, para todos os caracteres e nas duas gerações, a maior variância da interação G x E ocorreu para os genótipos tardios. Também é preciso salientar o tamanho da população em cada grupo de maturação. Segundo Soldini (1993) para se detectar qualquer associação entre a capacidade genotípica de adaptação às flutuações climáticas ao longo do ano agrícola, dentro de uma dada região, e o comprimento do ciclo biológico da planta, 
sugere-se o teste de um mesmo número de genótipos em cada grupo de maturação, 0 que permitirá avaliar os efeitos das interações com os mesmos graus de liberdade.

Os resultados apresentados nas Tabelas 19 a 21 indicam que as progênies precoces e intermediárias apresentariam maior estabilidade nas condições ambientais utilizadas nas duas gerações, considerando todos os caracteres, principalmente PG. Isso devido ao menor efeito do componente da interação. Um aspecto de importância a ser considerado na avaliação da magnitude da interação $\mathrm{G}$ x E entre grupos de maturação, refere-se à época de semeadura. Na época de semeadura considerada convencional, estabilizam-se melhor os genótipos precoces ou intermediários, resultado obtido neste estudo. A instalação de experimentos com genótipos de grupos de maturação diferentes, na mesma época, pode trazer dificuldades na avaliação da verdadeira resposta dos genótipos às condições ambientais, sugerindo-se o uso de duas ou três épocas de semeadura (Soldini, 1993).

Em geral, a variância da interação $G \times E$ aumentou na geração $F_{7: 3} \mathrm{em}$ relação à $F_{6: 3}$, talvez como efeito da seleção ou porque a capitalização da interação ( $G$ x E) não foi igual em magnitude para todos os genótipos.

Nas Tabelas 22 e 23 são apresentadas as proporções da interação G x E para as progênies em cada ciclo de maturidade para o caráter PG. Observa-se que as progênies de ciclo de maturidade tardio foram as que apresentaram a maior média e a maior variância da interação $\mathrm{G} \times \mathrm{E}$, sugerindo que os genótipos de maior produtividade contribuem mais para a variância da interação G x E. Por outro lado, isso pode ser devido ao fato das progênies tardias terem mais oportunidade de interagir com o 
ambiente. Esses resultados estão em concordância com Adegoke \& Frey (1987), em aveia. No entanto, são contrastantes com os encontrados por Baihaki et al. (1976) e Scott et al. (1994), em soja. Estes autores encontraram que os genótipos de menor produtividade tiveram uma maior contribuição para a variância da interação e concluíram que identificar uma grande proporção de genótipos de alta produtividade pode ser possível na presença da interação $G$ x E. Esses pesquisadores trabalharam num mesmo grupo de maturação e com igual número de genótipos para cada faixa de produtividade. Por outro lado, no presente estudo, além dos genótipos pertencerem a ciclos de maturidade diferentes, o número de progênies por ciclo também foi diferente, o que poderia explicar a discordância entre os resultados.

O fato de mais de $50 \%$ da interação $\mathrm{G} \times \mathrm{E}$ ter sido explicada pelo grupo de maior produtividade indica a necessidade de se fazer seleção através da avaliação em mais de um ambiente. Assim, não se corre o risco de descartar genótipos de alta produtividade. Também sugere que, para os materiais precoces e intermediários, de menor produtividade, o risco de perder genótipos superiores através da avaliação num só ambiente, é menor.

\subsection{Magnitude e natureza da interação $\mathbf{G} \times \mathbf{E}$}

O estudo da magnitude da interação $\mathrm{G}$ x E fornece subsídios ao melhorista quanto à estratégia de escolher genótipos de adaptação ampla ou de adaptação restrita 
a ambientes específicos. Na sua forma mais simples pode ser estimada a partir da análise conjunta da variância. Neste estudo, na geração $F_{6: 3}$ a interação $G \times E$ ao nível geral, foi significativa apenas para os caracteres NDM, PG e PO (Tabela 8); e na geração $\mathrm{F}_{7: 3}$ só para os caracteres PG e PO (Tabela 11). Isso indica que, em geral, caracteres quantitativos como PG são mais influenciados pelo ambiente e que na presença da interação, existem combinações específicas de genótipos e ambientes representando uma complicação para o melhorista (Vencovsky \& Barriga, 1992). Porém, os parâmetros estimados pela análise conjunta da variância, embora úteis, não fornecem uma indicação adequada da resposta dos genótipos aos diferentes ambientes onde são cultivados.

Uma maneira mais recomendável de entender a magnitude e natureza da interação G x E foi proposta por Robertson (1959), mediante a decomposição do quadrado médio da interação tratamentos $\mathrm{x}$ locais em um componente devido à diferença na variação entre tratamentos dentro de cada local, chamado de componente simples, e outro componente devido à falta de correlação entre o comportamento dos tratamentos de um local para outro, chamado de componente complexo. Segundo Vencovsky \& Barriga (1992), o importante é notar que o segundo componente é a parte problemática da interação, pois uma baixa correlação deve significar que o material genético superior num ambiente pode não sê-lo em outro e que a interação pode existir mesmo com alta correlação.

A decomposição do quadrado médio da interação $G \times E$ nos seus componentes (simples e complexo), para o caráter PG de forma geral e para cada ciclo 
de maturidade nas duas gerações, é mostrada também nas Tabelas 22 e 23 . Na geração $\mathrm{F}_{6: 3}$ (Tabela 22), observa-se que de maneira geral, o componente complexo, responsável por impedir a seleção de progênies promissoras para ambos os ambientes, simultaneamente, respondeu por $45 \%$ do total da interação; enquanto, o componente simples contribuiu com 55\%. Esse resultado indica que não existiria dificuldade em selecionar progênies superiores adaptadas a ambos os locais (correlação de 0,58 entre os desempenhos das progênies de um local para outro). De fato, das 210 progênies selecionadas na geração $\mathrm{F}_{6: 3}, 93$ foram comuns aos dois locais. Na distribuição das progênies em cada ciclo de maturidade observou-se comportamento semelhante dos componentes simples e complexo da interação.

Na geração $F_{7: 3}$, de maneira geral, a parte complexa foi responsável por $84 \%$ da interação, restando à parte simples, só $16 \%$. Isso reflete uma dificuldade maior em selecionar progênies superiores adaptados à ambos os locais e decorre da correlação baixa $(0,20)$ das progênies de um local para outro. Os resultados foram similares para cada ciclo de maturidade, embora os coeficientes de correlação fossem diferentes. Por exemplo, o coeficiente de correlação para as progênies precoces foi de 0,43 ; porém, para as tardias foi de $-0,23$. O fato do componente complexo ser maior nas progênies de ciclo tardio confirma a maior contribuição destas progênies para a variância da interação.

É importante salientar que apesar da baixa correlação e predomínio do componente complexo sobre o simples na geração $F_{7: 3}$, existem progênies que podem 
ser selecionadas com adaptação a ambos os locais. De fato, na seleção de progênies $F_{7: 3}$, 24 foram comuns aos dois locais.

Os dados para as duas gerações revelam que, devido ao efeito da seleção ou pela capitalização desigual da interação $\mathrm{G}$ x E para todos os genótipos, o componente complexo tende a aumentar, dificultando mais a seleção de progênies com bom comportamento numa gama ampla de ambientes. De fato, para o caráter PG, na geração $\mathrm{F}_{6: 3}$, a variância genotípica foi 1,78 vezes maior do que a variância da interação; já na geração $F_{7: 3}$, a variância da interação foi 3,95 vezes maior do que a genotípica.

\subsection{Ganhos genéticos com a seleção}

A possibilidade do melhorista estimar o ganho com a seleção antes mesmo que ela seja realizada é, sem dúvida, uma das principais contribuições da genética quantitativa (Ramalho et al., 1993). Esse parâmetro junto ao coeficiente de herdabilidade, coeficiente de variação genética e as correlações genéticas entre os caracteres permitem, ao melhorista, escolher o melhor método de melhoramento e determinar a eficiência de um programa de melhoramento, já em andamento.

Os ganhos genéticos esperados e observados com a seleção de progênies, na geração $\mathrm{F}_{6: 3}$, de forma geral e em cada ciclo de maturidade, para o caráter PG, são apresentados na Tabela 24. Para a geração $F_{7: 3}$, os ganhos esperados encontram-se na Tabela 25. 
Como foi apontado na seção de Material e Métodos, para separar o efeito ambiental (épocas) do efeito genético na geração $\mathrm{F}_{6: 3}$ os cálculos do ganho esperado e observado foram obtidos com base na média da população básica sem seleção e com base na média das testemunhas (população controle).

A separação das mudanças observadas entre os componentes genéticos e ambientais é uma parte importante na análise de experimentos nos programas de melhoramento. É raramente possível conduzir experimentos em condições uniformes sob períodos de várias gerações, de modo que as mudanças no comportamento de uma população selecionada pode refletir, em parte, alguns efeitos ambientais (Hill, 1972 Falconer, 1989). Segundo Hill (1972) um bom método para estimar essas mudanças genéticas é a utilização de populações controle não selecionadas. Essa estimativa é feita sob a suposição de que as diferenças ambientais afetam as populações (selecionadas e controle) por igual (Muir, 1986).

Com respeito aos ganhos esperados, os dados da Tabela 24 mostram que na geração $F_{6: 3}$, eles foram sempre maiores em Anhembi (seleção direta), resultado que era esperado com base nos maiores valores de média, variância genética e herdabilidade encontrados entre as progênies neste local.

A análise teórica da eficiência da seleção indireta (de um local para outro) e da seleção geral baseada na média dos dois locais sobre a seleção direta em cada local na geração $\mathrm{F}_{6: 3}$ é apresentada na Tabela 26 . Observa-se que de maneira geral a seleção indireta teria uma eficiência de $62 \%$. Nas progênies precoces, intermediárias e tardias 
essa eficiência seria de 49, 64 e 60\%, respectivamente. Segundo Falconer (1989) a maioria dos experimentos confirma que a teoria de encontrar respostas correlacionadas (de um local para outro) é menor do que a resposta direta; quer dizer que a seleção é mais efetiva se praticada no ambiente onde o experimento está sendo realizado.

A Tabela 26 também mostra que a seleção baseada na média geral dos dois locais sobre a seleção específica teria uma eficiência geral de $92 \%$ com perda apenas de $8 \%$. Essa eficiência por ciclo de maturidade seria de 89,90 e $93 \%$ para as progênies precoces, intermediárias e tardias, respectivamente, mostrando que a seleção baseada na média dos dois locais apresentou-se como uma boa alternativa. De fato, a seleção foi praticada utilizando essa estratégia.

No que diz respeito aos ganhos observados (Tabela 24) nota-se que aqueles estimados a partir da média da população básica (sem seleção) foram muito maiores do que os esperados, devido ao fato desses ganhos incluirem tanto o componente genético quanto o ambiental (épocas). Já os ganhos observados, estimados com base na média das testemunhas (população controle), foram inferiores aos ganhos esperados; sendo que o ganho foi aproximadamente 1/3 do esperado para os dois locais em conjunto e 2/3 do esperado para cada local.

Segundo Hill (1972) a precisão das estimativas de ganho genético através do uso da população controle é reduzida por várias razões: a) a população controle tem mudanças genéticas por si mesma; b) a população controle e a população sob seleção reagem de forma diferente às flutuações do ambiente; c) pelo tamanho das populações 
(erro de amostragem). No presente estudo, a população controle foi composta por quatro cultivares, selecionados principalmente pela produtividade de grãos. Os cultivares apresentam pouca variabilidade entre si e são adaptados à região, pelo que as duas últimas razões podem ser a causa da diferença entre os ganhos genéticos observados e esperados neste estudo; tal fato indicaria a impossibilidade de se separar os componentes genético e ambiental. Salienta-se, também, que a média da população controle foi obtida de quatro testemunhas, enquanto a média da população sob seleção foi obtida de 897 progênies em $F_{6: 3}$ e 210 em $F_{7: 3}$.

Segundo Muir (1986) o uso da população controle nem sempre permite a precisão com que a resposta é esperada e afirma que o procedimento de Hill (1972) produz estimativas viesadas do ganho genético na presença da interação genótipos $\mathbf{x}$ ambientes. $\mathrm{O}$ autor recomenda o uso da população controle como uma covariável, na qual o viés seria menor.

Para as progênies precoces e intermediárias, os ganhos observados estiveram mais próximos dos ganhos esperados. Porém, nas progênies tardias os resultados esperados e observados foram muito diferentes até o ponto de se obter um dado negativo no local Areão. Esse resultado está relacionado com a magnitude da variância da interação $\mathrm{G} \times \mathrm{E}$, em cada ciclo de maturidade. Foi mencionado anteriormente que as progênies tardias foram mais afetadas pela interação $\mathrm{G} \times \mathrm{E}$, nas duas gerações e em especial na $F_{7: 3}$, sendo que as precoces e intermediárias apresentaram-se como as mais estáveis. 
Na geração $F_{7: 3}$ (Tabela 25) como na geração $F_{6: 3}$, os ganhos genéticos esperados foram maiores no local Anhembi, como conseqüência da média, variância e herdabilidade obtidas nesse local. Analisando cada ciclo de maturidade observa-se que, para as progênies precoces, os ganhos esperados foram maiores do que aqueles para progênies intermediárias e tardias, ao contrário da geração $F_{6: 3}$. Esse resultado é explicado pelo fato das progênies precoces terem mantido a sua variância genética de uma geração para outra. Isto não se verificou para as progênies intermediárias e tardias, para as quais houve uma diminuição muito grande na variabilidade genética (inclusive estimativas de variâncias negativas, principalmente em Areão) possível causa dos ganhos esperados com valor zero na Tabela 25.

Na Tabela 27 observa-se que a eficiência da seleção indireta sobre a seleção específica na geração $\mathrm{F}_{7: 3}$ seria de $39 \%$ (geral) enquanto que a seleção baseada na média dos dois locais sobre a específica seria de $81 \%$. A diminuição da eficiência com respeito à geração $\mathrm{F}_{6: 3}$ é devida, principalmente, à diminuição da correlação das progênies de um local para outro mostrada nas Tabelas 22 e 23 e ao aumento da variância da interação G $\times$ E de uma geração para 'outra. Como foi mostrado anteriormente, o componente principal da variância da interação $\mathrm{G} \times \mathrm{E}$, na geração $\mathrm{F}_{7: 3}$, foi o componente complexo, que tende a impedir a seleção de genótipos que sejam promissores para os dois locais. Nesta geração, a seleção das progênies tambem foi realizada com base na média dos dois locais. 


\subsection{Comparação entre cadeias de cruzamentos}

A base genética estreita da soja como indicado por Vello (1995) leva a dois grandes problemas: estabelecimento de patamares de produtividade e vulnerabilidade do germoplasma aos estresses ambientais, incluindo-se suscetibilidade a patógenos; para evitar isto, atualmente vários pesquisadores têm trabalhado com o objetivo de aumentar essa base genética.

Entre os métodos mais estudados para esse fim estão a realização de cruzamentos interespecíficos (Mansur et al., 1993; Malik \& Singh, 1987) e a utilização de germoplasma exótico (PI'S) nos cruzamentos (Schoener \& Fehr, 1979; Vello et al., 1984; Pfeiffer et al., 1991).

Neste estudo, as progênies pertencem a duas cadeias de cruzamentos (mista e adaptada). Na Tabela 28 são apresentadas as estimativas de médias ajustadas e variâncias genotípicas das duas cadeias de cruzamentos, nas gerações $F_{6: 3}$ e $F_{7: 3}$, para todos os caracteres estudados.

$\mathrm{Na}$ geração $\mathrm{F}_{6: 3}$ as progênies dentro da cadeia adaptada apresentaram média e variância superiores à cadeia mista, para todos os caracteres, exceto os caracteres APM e VA (variância genotípica foi maior na cadeia mista). Já na geração $\mathrm{F}_{7: 3}$ a cadeia adaptada mostrou médias ajustadas superiores, porém, a cadeia mista apresentou, com exceção do caráter NDM, maior variância. 
Esses resultados podem se dever ao fato da seleção praticada na $F_{6: 3}$ ter contemplado as progênies com melhor média nos caracteres, principalmente PG e que corresponderam à cadeia adaptada, diminuindo a sua variância. Pode-se observar que na cadeia adaptada a variância diminuiu para todos os caracteres, visto que na cadeia mista a variância dos caracteres PG, \%OL e PO aumentou de uma geração para outra.

Os resultados da geração $\mathrm{F}_{7: 3}$ estão em concordância com os encontrados por Prijic (1993) de que as populações com genes provenientes de materiais exóticos apresentam maior variabilidade genética e menor média. Porém, no presente estudo, os resultados devem ser vistos com cautela porque existe já um efeito de seleção praticada em $\mathrm{F}_{6: 3}$.

Zimback (1992), Montaño-Velasco (1994) e Farias-Neto (1995), estudando as gerações $F_{2}$ a $F_{5}$ deste mesmo material, encontraram que a cadeia mista apresentou menor média e menor variância. Tais resultados concordam com os encontrados neste estudo para a geração $\mathrm{F}_{6: 3}$.

Existe um concenso entre os pesquisadores que para o imediato uso de uma população e para se incrementar o caráter PG, existe pouca justificativa para o uso de parentais exóticos e que estes podem ser usados em programas de melhoramento a longo prazo, através de vários ciclos de seleção recorrente. 


\subsection{Correlações entre caracteres}

As estimativas dos coeficientes de correlação genotípica, fenotípica e ambiental envolvendo a associação entre os caracteres número de dias para a maturidade (NDM), altura da planta na maturidade (APM), valor agronômico (VA), produtividade de grãos (PG), porcentagem de óleo (\%OL) e produtividade de óleo (PO), em cada local, através dos dois locais (combinado) e nas duas gerações, são apresentados na Tabela 29. A magnitude dessas estimativas variou de um local para outro nas duas gerações, mostrando a influência dos locais sobre a expressão genotípica das progênies. Essa influência dos locais também foi encontrada por Soldini (1993) e a influência das épocas de semeadura, por Farias Neto (1987).

Foram observadas também algumas variações ao nível de conjunto (combinado) entre as gerações, principalmente no que diz respeito à associação do caráter NDM com os outros caracteres. Isso evidencia a influência da época de semeadura e o efeito da seleção que muda as variâncias genéticas sobre esse caráter. Por exemplo, os dados mostram uma correlação genotípica alta e positiva entre NDM e os caracteres PG, APM, VA e PO na geração $F_{6: 3}$. Entretanto, na geração $F_{7: 3}$, essas correlações são baixas e algumas vezes, até negativas. A \%OL foi outro caráter que evidenciou variação entre locais e épocas.

Com algumas exceções, a correlação genotípica foi maior do que a fenotípica, resultado encontrado na maioria da literatura citada (Apêndice 2) e indica a 
interferência do ambiente na expressão fenotípica, a qual dificulta a seleção indireta (Santos et al., 1995a).

De maneira geral, os resultados mostraram que houve concordância de sinais nas correlações fenotípicas e genotípicas e que, entre as correlações genotípicas e ambientais, existiram dados com sinal diferente. Segundo Falconer (1989), o fato das correlações ambientais e genotípicas apresentarem sinal e magnitude diferentes, indica que as causas de variação genética e ambiental apresentam diferentes mecanismos fisiológicos, prejudicando a seleção indireta.

Os dados apresentam uma correlação genotípica alta e positiva entre PG com NDM, APM, VA e PO e uma correlação positiva, embora baixa entre PG e \%OL, na geração $F_{6: 3}$. Isso também ocorre na geração $F_{7: 3}$, exceto pela correlação baixa e negativa de PG com NDM. Esses resultados indicam que, nas duas gerações (diferentes épocas de semeadura), poderiam ser obtidas progênies com altos valores de APM, PG, VA e PO. No entanto, na época de outono/inverno (geração $F_{6: 3}$ ), seria muito difícil unir essas características com precocidade. Farias Neto (1987) também encontrou correlação fenotípica positiva e significativa entre PG e NDM na época de outono/inverno, mas não na época de verão.

A associação entre os caracteres PG e APM na época de outono/inverno, é de fundamental importância na obtenção de cultivares superiores para cultivo de outono/inverno ou para áreas de baixa latitude; principalmente quando se toma o caráter APM como indicativo da presença de genes para florescimento tardio em dias curtos. 
Uma das estimativas mais estáveis através dos locais e das épocas de semeadura foi a correlação genotípica entre APM e VA, a qual sempre foi alta e positiva. Esse resultado também foi obtido por Zimback (1992), Montaño-Velasco (1994) e Farias Neto (1995), mostrando a grande influência do caráter APM na avaliação do caráter VA. As altas associações entre o caráter VA com os caracteres PG, APM e PO, entre PG com APM e PO e entre APM com PO, permitem avaliar que VA seria eficiente em selecionar genótipos superiores.

Com respeito ao caráter porcentagem de óleo (\%OL), a correlação encontrada com os outros caracteres foi baixa e, ao nível de análise conjunta (combinado), foi positiva com os caracteres PG, APM, VA e PO. A correlação entre \%OL e NDM, ao nível conjunto, foi positiva na geração $\mathrm{F}_{6: 3}$; entretanto, na geração $F_{7: 3}$, foi negativa. A correlação baixa entre \%OL e os outros caracteres já tem sido encontrada pela maioria dos pesquisadores (Apêndice 2), sendo que o caráter que apresenta correlação alta e negativa com \%OL é o teor de proteína, caráter não avaliado neste estudo.

Leffel (1989), citado por Orf \& Helms (1994), salienta que, baseado nos últimos anos de pesquisa, o resultado provável do melhoramento contínuo para alta produtividade de grãos na soja resultará em alto teor de óleo e baixa proteína. Isso como conseqüência da correlação positiva, embora baixa, de PG com \%OL e alta e negativa do caráter proteína com esses dois caracteres. 
A correlação baixa e positiva do caráter \% OL com os caracteres PG e PO, junto à correlação alta e positiva entre esses dois últimos caracteres, associada à pouca variabilidade do caráter \%OL indicam que a produtividade de óleo (PO) depende mais significativamente da seleção para produtividade de grãos (PG), como afirmado também por Farias Neto (1995).

Burton \& Brim (1981) já haviam afirmado que embora a porcentagem de óleo possa ser aumentada na soja, através de seleção, o óleo total produzido por unidade de área pode não aumentar, a menos que a produtividade de grãos aumente ou permaneça constante. Por isso, dependendo dos objetivos da seleção, é necessário considerar tanto a produtividade de grãos quanto o teor de óleo.

\subsection{Análise reunindo as gerações $F_{6: 3}$ e $F_{7: 3}$}

\subsubsection{Análise de variância}

Considerando que o grau de homozigose nas gerações $F_{6: 3}$ e $F_{7: 3}$ é alto, foi realizada uma análise de variância com os dados das 210 progênies selecionadas em $F_{6: 3}$ (Tabela 30). $O$ quadrado médio do erro médio conjunto geral foi obtido pela média entre o erro efetivo médio geral da Tabela 8 (análise conjunta da geração $\mathrm{F}_{6: 3}$ ) e $o$ erro medio da Tabela 11 (análise conjunta da geração $F_{7: 3}$ ), ponderando pelos graus de liberdade. 
A análise mostra que entre locais houve diferença para os caracteres PG, PO e APM. Entre épocas existiu diferença nos caracteres NDM, APM, PG \%OL e PO, resultado esperado pelas análises de cada geração e pelo fato das épocas serem totalmente diferentes. A interação locais $\mathrm{x}$ épocas foi significativa unicamente para os caracteres NDM e \%OL.

O caráter VA é uma qualificação visual do melhorista e é própria de cada experimento pelo que depende principalmente do comportamento geral da população que está sob avaliação no experimento. Isso explica a não significância para esse caráter nas fontes de variação de locais e épocas.

Entre cruzamentos houve diferenças significativas para os caracteres NDM, APM e VA. Entre as progênies em geral, houve diferenças significativas para todos os caracteres, exceto PO.

Entre as progênies intermediárias e tardias não houve diferença significativa para nenhum caráter. Porém, entre as progênies precoces houve diferenças para todos os caracteres. As progênies em geral não apresentaram interação com locais para nenhum caráter. A interação com épocas aconteceu para os caracteres APM, \%OL e VA, sendo que a tripla interação ocorreu nos caracteres APM, PG e PO.

As interações de locais e épocas foram negligíveis para todos os caracteres, nos três ciclos de maturidade, com exceção da interação épocas x genótipos para o caráter VA, nas progênies precoces. Todos os ciclos de maturidade apresentaram interação tripla para os caracteres PG e PO, além do caráter APM nas progênies 
intermediárias. A maioria de estudos sobre interação $G \times E$ na literatura mostram interação genótipos x locais, genótipos x épocas (anos) e a tripla interação (Baihaki et al., 1976; Toledo et al., 1994; Pfeiffer et al., 1995) evidenciando a importância deste tipo de estudo.

\subsubsection{Componentes de variância e herdabilidade}

Na Tabela 31 são apresentadas as estimativas de médias ajustadas, variâncias genotípicas $\left(\sigma_{\mathrm{g}}^{2}\right)$, variâncias da interação genótipos $\mathrm{x}$ locais $\left(\sigma_{\mathrm{gxx}}^{2}\right)$, variância da interação genótipos $\mathrm{x}$ épocas $\left(\sigma_{\mathrm{gxa}}^{2}\right)$, variância da interação tripla ou de segunda ordem $\left(\sigma_{\mathrm{gx} \times \mathrm{a}}^{2}\right)$, variância do erro médio conjunto geral $\left(\sigma_{\mathrm{e}}^{2}\right)$ e coeficiente de herdabilidade $\left(\mathrm{h}^{2}\right)$, obtidas a partir da análise apresentada na Tabela 30 .

Chama muito a atenção o valor relativamente pequeno das variâncias genotípicas quando comparadas às variâncias dos erros, em todos os caracteres. Porém, de maneira geral, as variâncias genotípicas foram maiores do que as variâncias das interações, com exceção dos caracteres PG e PO. Segundo Zhou \& Zhu (1994) na maioria de estudos desta natureza, a variância genotípica é maior do que as das interações, isso foi encontrado neste estudo para os caracteres NDM, APM, VA e \%OL. Kwon \& Torrie (1964) também encontraram resultados similares para todos os caracteres, exceto para o caráter PG. 
Freqüentemente a interação genótipos $\mathrm{x}$ épocas (anos) é maior do que genótipos $\mathrm{x}$ locais e a interação genótipos $\mathrm{x}$ locais $\mathrm{x}$ épocas é menor do que as duas anteriores. No presente estudo isso aconteceu para o caráter \%OL nas progênies em geral e nas precoces, e para o caráter NDM.

Para o caráter \%OL, nas progênies em geral e nas precoces, a variância genotípica foi maior, seguida pelas interações genótipos $\mathrm{x}$ épocas, genótipos $\mathrm{x}$ locais $\mathrm{e}$ genótipos $\mathrm{x}$ locais $\mathrm{x}$ épocas. Porém, para as progênies intermediárias e tardias a maior variância foi a da interação genótipos $\mathrm{x}$ épocas e genotípica, respectivamente. Encontrou-se também que a influência da interação para esse caráter foi menor do que para o caráter PG, resultado também encontrado por Schutz \& Bernard (1967).

De maneira geral, mesmo com a diferença do estado nutricional do solo (Apêndice 5b), as diferenças de época acabaram sendo uma fonte mais importante de variação do que as diferenças devido aos locais, exceto para o caráter PG e PO em todos os ciclos de maturação.

Também de maneira geral, as progênies menos afetadas pelas interações foram as intermediárias, resultado que também já havia sido encontrado nas análises de cada geração. Houve uma certa variação no valor das estimativas, tanto de um caráter para outro como de um ciclo de maturidade para outro, mesmo assim, os dados indicam, a exceção das progênies tardias no caráter PG e PO e as progênies intermediárias no caráter \%OL, a presença de variabilidade genética entre as progênies. Existindo, portanto, a possibilidade de se obter melhoramento em cada um dos caracteres por meio de seleção. 
As variâncias genotípicas estimadas a partir da Tabela 30, são, em teoria mais precisas do que as obtidas na geração $F_{7: 3}$ para estas mesmas progênies (Tabelas 18-21) e se aproximam mais da verdadeira variância genotípica devido que foram removidas as variâncias devido às interações genótipos $\mathrm{x}$ locais, genótipos $\mathrm{x}$ anos $\mathrm{e}$ genótipos $\mathrm{x}$ locais $\mathrm{x}$ anos. $\mathrm{O}$ mesmo acontece com as estimativas dos coeficientes de herdabilidade. Quanto mais precisas forem essas estimativas, melhores serão as previsões de ganho genético com a seleção.

Segundo Allard (1971), pode haver uma grande variabilidade nas estimativas das variâncias que são úteis para o melhorista de plantas. Essa variabilidade depende muito da unidade ambiental para a qual as variâncias são consideradas. Quando os genótipos são ensaiados uma só vez e num só local, a soma $\sigma_{\mathrm{g}}^{2}+\sigma_{\mathrm{gl}}^{2}+\sigma_{\mathrm{ga}}^{2}+\sigma_{\text {gla }}^{2}$, é estimada como variância genética. Fazendo-se comparação em épocas diferentes, mas num só local, as quantidades estimadas são $\sigma_{\mathrm{g}}^{2}+\sigma_{\mathrm{gl}}^{2}$ e $\sigma_{\mathrm{ga}}^{2}+\sigma_{\mathrm{gla}}^{2}$. Se a comparação é feita em dois locais, mas numa época ou num só ano, as variâncias estimadas são $\sigma_{g}^{2}+\sigma_{g x a}^{2}$ e $\sigma_{g l}^{2}+\sigma_{g l a}^{2}$. 


\section{CONCLUSÕES}

Os resultados obtidos neste estudo permitem as seguintes conclusões:

a) Nas duas gerações, apesar da seleção praticada, foi observada variabilidade genética entre as progênies para os caracteres APM, VA, PG e PO; para \%OL foi observada variação só entre as progênies precoces.

b) A semeadura na época de outono/inverno permitiu detectar e selecionar progênies com florescimento tardio em dias curtos (período juvenil longo), utilizando os caracteres NDM e APM como indicadores da presença de genes que manifestam essa característica.

c) Nas duas gerações, a presença da interação genótipos $\mathrm{x}$ locais foi diferente entre caracteres e entre ciclos de maturidade; para os caracteres PG e PO houve interação nos três ciclos de maturidade, indicando existência de um comportamento diferencial das progênies nos dois locais. 
d) As progênies tardias foram as mais produtivas e as que apresentaram maior variância da interação $\mathrm{G} \times \mathrm{E}$, nas duas gerações, evidenciando a importância de avaliar esses genótipos em mais de um ambiente; as progênies intermediárias foram as menos influenciadas pela interação $\mathrm{G} \times \mathrm{E}$.

e) Na geração $F_{6: 3}$, o principal componente da interação $G \times E$ foi a parte simples (55\%); já na geração $\mathrm{F}_{7: 3}$, o componente complexo foi responsável pela maior parte da interação G x E (84\%).

f) O local Anhembi foi superior permitindo aos genótipos expressarem melhor o seu potencial genético, resultando em maiores médias (principalmente para PG), maiores variâncias genéticas em todos os caracteres e maiores ganhos genéticos esperados e observados.

g) A seleção é mais efetiva se praticada no ambiente onde o experimento está sendo realizado (seleção direta), principalmente se este ambiente é favorável ou não causa estresse.

h) Apesar das estimativas das correlações genotípicas, fenotípicas e ambientais entre os caracteres terem sido influenciadas pelos locais, evidenciou-se a possibilidade de selecionar progênies combinando altos valores nos caracteres PG, PO, APM e VA. 
i) Os cruzamentos que se sobressaíram pela média e variância nos caracteres NDM, APM, VA, PG e PO foram: IAC-9 x GO 79-1030 (34x35), IAC-6 x UFV-4 (37x38), AX 5355-s x Paranagoiana (13x14), Cristalina-s x IAC-6 (36x37), BR-9 x EMGOPA-

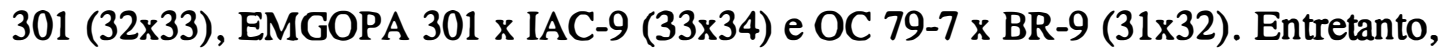
os cruzamentos com maior média para porcentagem de óleo $(\% \mathrm{OL})$ foram aqueles envolvendo os parentais Planalto-s, BR 80-15725-B-s e GO 81-8491.

j) A maximização da produtividade de óleo (PO) grãos do que do teor de óleo. 


\section{REFERÊNCIAS BIBLIOGRÁFICAS}

ABLETT, G.R.; BUZZELL, R.I.; BEVERSDORF, W.D.; ALLEN, O.B. Comparative stability of 40 indeterminate and semideterminate soybean lines. Crop Science, v.34, n.2, p.347-351, Mar./Apr. 1994.

ADEGOKE, A.O.; FREY, K.J. Grain yield response and stability for oat lines with low-, medium- and high-yielding ability. Euphytica, v.36, n.1, p.121-127, 1987.

ALLARD, R.W. Princípios do melhoramento genético das plantas. New York, John Wiley \& Sons, 1971. 381p.

ALLARD, R.W.; BRADSHAW, A.D. Implications of genotype-environmental interactions in applied plant breeding. Crop Science, v.4, p.503-508, 1964.

ALLEN, E.F.L.; COMSTOCK, R.E.; RASMUSSON, D.C. Optimal environments for yield testing. Crop Science, v.18, n.5, p.747-751, Sep./Dec. 1978.

ANAND, S.C.; TORRIE, J.H. Heritability of yield and other traits and interrelationships among traits in the $\mathrm{F}_{3}$ and $\mathrm{F}_{4}$ generations of three soybean crosses. Crop Science, v.3, n.6, p.508-511, 1963.

BAIHAKI, A.; STRUKER, R.E.;LAMBERT, J.W. Association of genotype $x$ environment interations of soybean lines in preliminary yield tests. Crop Science, v.16, n.5, p.718-721, Sep./Dec. 1976. 
BARTLEY, B.G.; WEBER, C.R. Heritable and non-heritable relationships and variability of agronomic characters in successive generations of soybean crosses. Agronomy Journal, v.44, n.9, p.487-493, Sept. 1952.

BONATO, E.R.; DALL'AGNOLL, A. Soybean in Brazil - Production and research. In: WORLD SOYBEAN RESEARCH CONFERENCE, 3., Ames, 1984. Proceedings. Bouder, Westview Press, 1985. p.1248-1256.

BONETTI, L.P. The use of single seed selection in combination with single seed descent for modifying oil content in soybeans (Glycine max (L.) Merrill). Champaign, 1978. 63p. (M.Sc.) - University of Illinois at Urbana.

BRIM, C.A. Quantitative genetics and breeding. In: CALDWELL, B.E., ed. Soybean: improvement, production and uses. Madison: American Society of Agronomy, 1973. p.155-186. (Agronomy, 16).

BRIM, C.A.; COCKERHAM, C.C. Inheritance of quantitative characters in soybeans. Crop Science, v.1, n.3, p.187-190, May/June 1961.

BRIM, C.A.; STUBER, C.W. Application of genetic male sterility to recurrent selection schemes in soybeans. Crop Science, v.13, n.5, p.528-530, Sep./Oct. 1973.

BURTON, J.W.; BRIM, C.A. Recurrent selection in soybeans. III. Selection for increased percent oil in seeds. Crop Science, v.21, n.1, p.31-34, Jan./Feb. 1981.

BURTON, J.W.; CARVER, B.F. Selection among $S_{1}$ families vs. selfed half-sib or full-sib families in autogamous crops. Crop Science, v.33, n.1, p.21-28, Jan./Feb. 1993. 
BURTON, J.W.; KOINANGE, E.M.K.; BRIM, C.A. Recurrent selfed progeny selection for yield in soybean using genetic male sterility. Crop Science, v.30, n.30, p.1222-1226, Nov./Dec. 1990.

CARVER, B.F.; BURTON, J.W.; WILSON, R.F.; CARTER JR. T.E. Cumulative response to various recurrent selection schemes in soybean: oil quality and correlated agronomic raits. Crop Science, v.26, n.5, p.853-858, Sep./Oct. 1986.

CHAUHAN, V.S.; SINGH, B.B. Heterosis and genetic variability in relation to genetic divergence in soybean. The Indian Journal of Genetic \& Plant Breeding, v.42, n.3, p.324-328, Nov. 1982.

COCKERHAM, C.C. Estimation of genetics variance In: HANSON, W.D.; ROBINSON, H.F., ed. Statistical genetics and plant breeding. Madison: National Academy of Sciences, 1963. p.53-94.

CRUZ, C.D.; REGAZZI, A.J. Modelos biométricos aplicados ao melhoramento genético. Viçosa: UFV, Impr. Univ., 1994. 390p.

DASHIEL, K.E.; ARIYO, O.J.; BELLO, L.; OJO, K. Genotype x environment interaction and simultaneous selection for high yield and stability in soybeans (Glycine max (L.) Merr.). Annals Applied Biology, v.124, p.133-139, 1994.

FALCONER, D.S. Introduction to quantitative genetics. 3rd ed. New York, Longman, 1989. 438p.

FARIAS NETO, J.T. Comportamento e variabilidade de genótipos de soja (Glycine $\max ($ L.) Merrill) em cultivos de verão e inverno. Piracicaba, 1987. 87p. Dissertação (Mestrado) - Escola Superior de Agricultura "Luiz de Queiroz", Universidade de São Paulo. 
FARIAS NETO, J.T. Potencialidade de progênies $F_{4: 3}$ e $F_{5: 3}$ derivadas de cruzamentos em cadeia para produtividade de óleo em soja. Piracicaba, 1995. 150p. Tese (Doutorado) - Escola Superior de Agricultura "Luiz de Queiroz", Universidade de São Paulo.

FATMI, A.; WAGNER, D.B.; PFEIFFER, T.W. Intermating schemes used to synthesize a population are equal in genetic consequences. Crop Science, v.32, n.1, p.89-94, Jan./Feb. 1992.

FREIRE FILHO, F.R. Análise genética de um dialelo entre genótipos precoces de soja (Glycine max (L.) Merrill). Piracicaba, 1988. 224p. Tese (Doutorado) - Escola Superior de Agricultura "Luiz de Queiroz", Universidade de São Paulo.

GATES, C.E.; WEBER, C.R.; HORNER, T.W. A linkage study of quantitative characters in soybean cross. Agronomy Journal, v.52, n.1, p.45-49, Jan. 1960.

HALLAUER; A.R.; MIRANDA FILHO, J.B. Quantitative genetics in maize breeding. 2.ed, Ames, Iowa State University Press, 1988. 468p.

HANSON, W.D.; WEBER, C.R. Analysis of genetic variability from generations of plant-progeny lines in soybeans. Crop Science, v.2, n.1, p.63-67, Jan./Feb. 1962.

HILL, W.G. Estimation of genetic change. I. General Theory and Design of Control Populations. Animal Breeding Abstracts, v.40, n.1, p.1-15, Mar. 1972.

HIROMOTO, D.M.; VELLO, N.A. The genetic base of Brazilian soybean (Glycine $\max ($ L.) Merrill) cultivars. Brazilian Journal of Genetics, v.9, n.2, p.295-306, Jun. 1986. 
IGLESIAS, L. Estudio de la variabilidad genética de los principales caracteres productivos en soya (Glycine max (L.) Merrill). Cultivos Tropicales, v.10, n.2, p.85-91, Jun. 1988.

JOHNSON, H.W.; ROBINSON, H.F.; COMSTOCK, R.E. Estimates of genetic and enviromental variability in soybeans. Agronomy Journal, v.47, n.7, p.314-318, Jul. 1955.

KEMPTHORNE, O. An introduction to genetic statistics. Ames, Iowa State University Press, 1973. 545p.

KENWORTHY, W.J.; BRIM, C.A. Recurrent selection in soybeans. I. Seed yield. Crop Science, v.19, n.3, p.315-318, May/June 1979.

KRETCHMER, P.J.; KRETCHMER, N. The contribution of horticultural crops and the role of omega-3 fatty acids in health. In: QUEBEDEAUX, B.; BLISS, F.A., ed. Horticulture and human health: contributions of fruits and vegetable. Alexandria: American Society of Horticultural Science, 1987. p.108-120.

KWON, S.H.; TORRIE, J.H. Heritability of and interrelationships among traits of two soybean populations. Crop Science, v.1, p.196-198, 1964.

LAL, V.S.; HAQUE, M.F. Genotypic and phenotypic variability in quantitative characters in soybean (Glycine max (L.) Merr.). Indian Journal of Agricultural Science, v.42, n.1, p.30-33, 1972.

LOISELLE, F.; VOLDENG, H.D.; TURCOTTE, P.; ST-PIĖRRE, C.A. Analysis of agronomic characters for an eleven-parent diallel of early-maturing soybean genotypes in Eastern Canada. Canadian Journal of Plant Science, v.70, p.107-115, Jan. 1990. 
LUEDDERS, V.D. Genetic improvement in yield of soybeans. Crop Science, v.17, n.6, p.971-972, Nov./Dec. 1977.

MACHADO dos SANTOS, V.L.; SEDIYAMA, C.S.; SEDIYAMA, T.; MORAES, C.F. de. Estimativa de herdabilidade em geração $F_{2}$ de verão e $F_{3}$ de inverno em soja. Revista Ceres, v.34, n.191, p.64-70, 1987.

MAHMUD, I.; KRAMER, H.H. Segregation for yield, height and maturity following a soybean cross. Agronomy Journal, v.43, n.12, p.605-609, Dec. 1951.

MALAVOlTA, E.; VITTI, G.C.; OLIVEIRA, S.A. de. Avaliação do estado nutricional das plantas: princípios e aplicações. Piracicaba: Potafos, 1989. 201p.

MALIK, S.S.; SINGH, B.B. Genetic variability and heritability of interespecific crosses of soybean. Indian Journal of Agricultural Sciences, v.57, n.2, p.122-124, Feb. 1987.

MANSUR, L.M.; LARK, K.G.; KROSS, H.; OLIVEIRA, A. Interval mapping of quantitative trait loci for reproductive morphological and seed traits of soybean (Glycine max (L.) Merrill). Theoretical and Applied Genetics, v.86, p.907-913, 1993.

McKENDRY, A.L.; McVETTY, P.B.E.; VOLDENG, H.D. Inheritance of seed protein and seed oil content in early maturing soybean. Canadian Journal and Genetic and Citology, v.27, n.5. p.603-7, Oct. 1985.

MIRANDA, M.A.C. de; MASCARENHAS, H.A.A.; PEREIRA, J.V.C.N.A.; GALLO, P.B.; LIMA, D.S.R.; PINZAN, N.R. Soja: avaliação de linhagens com período juvenil longo e obtenção de cultivar IAC-15. Bragantia, v.49, n.2, p.253-268, Ago. 1990. 
MIRANDA, M.A.C. de; TEIXEIRA, J.P.F.; MASCARENHAS, H.A.A.; RETTORI, C. Possibilidade de seleção recorrente para aumento de teor de óleo em soja com a utilização da macho-esterilidade genética e da espectroscopia de ressonância nuclear magnética. Bragantia, v.48, n.2, p.157-172, June 1989.

MONTAÑO-VELASCO, J.C. Análise genética de progênies $F_{3}$ de soja derivadas de cruzamentos em cadeia com ênfase na produtividade de óleo. Piracicaba, 1994. 115p. Tese (Doutorado) - Escola Superior de Agricultura "Luiz de Queiroz", Universidade de São Paulo.

MONTEVERDE, E. Correlaciones fenotípicas y genotípicas entre rendimiento, proteína, aceite y otras características en soja (Glycine max (L.) Merrill). Revista de la Facultade de Agronomia, v.13, n.1/4, p.183-214, Dic. 1984.

MUIR, W.M. Estimation of response to selection and utilization of control populations for additional information and accuracy. Biometrics, v.42, n.2, p.381-391, June 1986.

NELSON, R.L. Measuring seed yield in soybean populations segregating for male sterility. Crop Science, v.27, n.4, p.632-634, Jul./Aug. 1987.

OPENSHAW, S.J.; HADLEY, H.H. Selection indeces to modify protein concentration of soybean seeds. Crop Science, v.24, n.1, p.1-4, Jan./Feb. 1984.

ORF, J.H.; HELMS, T.C. Selection to maximize cross value for hectare within three soybean populations. Crop Science, v.34, n.5, p.1163-1167, Sep./Oct. 1994.

PFEIFFER, T.W.; GRABAU, L.J.; ORF, J.H. Early maturity soybean production system: genotype $\mathrm{x}$ environment interaction between regions of adaptation. Crop Science, v.35, p.108-112, Jan./Feb. 1995. 
PFEIFFER, T.W.; HILDEBRAND, O.F.; TEKRONY, D.M. Agronomic performance of soybean lipoxigenase isolines. Crop Science, v.32, n.2, p.357-362, Mar./Apr. 1992.

PFEIFFER, T.W.; SURYATI, D.; EGLI, D.B. Soybean plant introductions selected for seed filling period or yield: performance as parents. Crop Science, v.31, n.6, p.1418-1421, Nov./Dec. 1991.

PHUL, P.S.; SHARMA, S.R. Screening of soybean germplasm for high-protein and high oil lines. Soybean Genetics Newsletter, v.20, p.68-69, May 1993.

PIMENTEL GOMES, F. Curso de Estatística Experimental. 13ed. Piracicaba, Escola Superior de Agricultura "Luiz de Queiroz"/USP. 1990. 468p.

PIPER, T.E.; FEHR, W.R. Yield improvement in a soybean population by utilizing alternatives strategies of recurrent selection. Crop Science, v.27, n.2, p.172-180, Mar./Apr. 1987.

PRIJIC, L.M. Performance of $\mathrm{AP}_{6}, \mathrm{AP}_{12}$ and $\mathrm{AP}_{14}$ population progeny. Soybean Genetic Newletters, v.20, p.212-215, May 1993.

RAMALHO, M.A.P.; SANTOS, J.B. dos; ZIMMERMANN, M.J.O. Genética quantitativa em plantas autógamas. Aplicações ao melhoramento do feijoeiro. Goiânia, Editora da UFG, 1993. 271p.

ROBERTSON, A. The sampling variance of the genetic correlation coefficient. Biometrics, v.15, n.3, p.469-485, Sept. 1959.

ROBINSON, H.F.; COCKERHAM, C.C. Estimación y significado de los parâmetros genéticos. Fitotecnia Latinoamericana, v.2, n.1/2, p.23-28, 1965. 
RODRIGUEZ de CIANZIO, S.; CAVINS, J.F.; FEHR, W.R. Protein and oil percentage of temperate soybean genotypes evaluated in tropical enviroments. Crop Science, v.25, p.602-606, Jul./Aug. 1985.

ROESSING, A.C. Situação mundial das oleaginosas. Informe Econômico CNPso, v.2, n.2, p.5-20, agosto, 1995.

ROSE, I.A. Evaluation of soybean breeding lines by examining their responses to sowing date and row spacing. Australian Journal of Experimental Agriculture, v.27, n.5, p.721-726, 1987.

ROSE, J.L.; BUTLER, D.G.; RYLEY, M.J. Yield improvement in soybeans using recurrent selection. Australian Journal of Agricultural Research, v.43, p. 135-144, 1992.

ROSIELLE, A.A.; HAMBLIN, J. Theoretical aspects of selection for yield in stress and non-stress environments. Crop Science, v.21, n.6, p.943-946, Nov./Dec. 1981.

SANTOS, C.A.F.; REIS, M.S.; SEDIYAMA, C.S.; CRUZ, C.D.; SEDIYAMA, T. Parâmetros genéticos e seleção indireta em progênies $\mathrm{F}_{6}$ de um cruzamento de soja (Glycine max (L.) Merrill). Revista Ceres, v.42, n.240, p.155-166, 1995 a.

SANTOS, C.A.F.; REIS, M.S.; CRUZ, C.D. SEDIYAMA, C.S.; SEDIYAMA, T. Adequação de modelos no estudo do coeficiente de trilha dos componentes primários e secundários de progênies $\mathrm{F}_{6}$ de soja (Glycine max (L.) Merrill). Revista Ceres, v.42, n.240, p.111-121, Mar./Abr. 1995 b.

SAS Institute Inc. SAS User's Guide: Statistic, version 5 Edition. Cary, NC: SAS Institute Inc, 1985. 956p. 
SCHNEBLY, S.R.; FEHR, W.R. Effect of years and planting dates on fatty acid composition of soybean genotypes. Crop Science, v.33, n.4, p.716-719, July/Aug. 1993.

SCHOENER, C.S.; FEHR, W.R. Utilization of plant introductions in soybean breeding populations. Crop Science, v.19, n.2, p.185-188, Mar./Apr. 1979.

SCHUTZ, W.M.; BERNARD, R.L. Genotype $\mathrm{x}$ environment interaction in the regional testing of soybean strains. Crop Science, v.7, n.2, p.125-130, Mar./Apr. 1967.

SCOTT, R.A.; CHAMPOUX, M.; SCHAPAUGH, Jr. W.T. Influence of environment productivity levels and yield stability on selection strategies in soybean. Euphytica, v.78, n.1/2, p.115-122, 1994.

SHANNON, J.G.; WILCOX, J.R.; PROBST, A.H. Estimated gains from selection for protein and yield in the $\mathrm{F}_{4}$ generation of six soybean populations. Crop Science, v.12, n.6, p.824-826, Nov./Dec. 1972.

SHORTER, R.; BYTH, D.E.; MUNGOMERY, V.E. Genotype x environment interactions and environmental adaptation. II. Assessment of environmental contributions. Australian Journal of Agricultural Research, v.28, p.223-235, 1977.

SMITH, R.R.; WEBER, C.R. Mass selection by specific gravity for protein and oil in soybean populations. Crop Science, v.8, n.3, p.373-377, May/June 1968.

SOARES, P.C.; SEDIYAMA, C.S.; CRUZ, C.D.; SILVA, J.C. Genotype x Environment interaction and indirect selection of rice in irrigated and nonirrigated flood plain areas. Brazilian Journal of Genetics, v.18, n.4, p.563-568, Dec. 1995. 
SOLDINI, D.O. Interação genótipos $\mathbf{x}$ locais e correlações entre caracteres com ênfase na produtividade de óleo em soja. Piracicaba, 1993. 136p. Dissertação (Mestrado) Escola Superior de Agricultura "Luiz de Queiroz", Universidade de São Paulo.

SOUZA JÚNIOR, C.L. Componentes da variância genética e suas aplicações no melhoramento vegetal. Piracicaba-FEALQ. Piracicaba, 1989. 134p.

ST MARTIN, S.K. A new recurrent selection scheme incorporating genetic male sterility. Soybean Genetics Newsletter, v.8, p.107-109, Apr. 1981.

SUMARNO; FEHR, W.R. Response to recurrent selection for yield soybeans. Crop Science, v.22, n.2, p.295-299, Mar./Apr. 1982.

TAKEDA, R.W.; SANTOS, J.B. dos; RAMALHO, M.A.P. Progeny test for the "ESAL 501" x A 354" common bean (Phaseolus vulgaris L.) hybrid at different locations. Brazilian Journal of Genetics, v.14, n.3, p.771-779, 1991.

TEIXEIRA, J.P.F.; RAMOS, M.T.B.; MIRANDA, M.A.C. de; MASCARENHAS, H.A.A. Relação entre os principais constituintes químicos de grãos de soja. In: SEMINÁRIO NACIONAL DE PESQUISA DE SOJA, 3., Campinas, 1984. Anais. Londrina, EMBRAPA-CNPs, 1984.

TINIUS, C.N.; BURTON, J.W.; CARTER, JR. T.E. Recurrent selection for seed size in soybean: III. Indirect effects on seed composition. Crop Science, v.33, n.5, p.959-962, Sep./Oct. 1993.

TOLEDO, J.F.F.; ALMEIDA, L.A.; HILL, R.F.S.; MENOSSO, O.G. Ganho genético em soja no estado do Paraná, via melhoramento. Pesquisa Agropecuária Brasileira, v.25, p.89-94, 1990. 
TOLEDO, J.F.F.; OLIVEIRA, M.F.; TSUTIDA, A.C.; KIIHL, R.A.S. Genetic analysis of growth of determinate soybean genotypes under three photoperiods. Brazilian Journal of Genetics, v.16, n.3, p.713-748, Sept. 1993.

TOLEDO, J.F.F. de; TRILLER, C.; DONATO, L.T.; OLIVEIRA, M.F. de; TSUTIDA, A.C. Genetic control of flowering in determinate soybean genotypes under diverse photoperiods. Brazilian Journal of Genetics, v.17, n.2, p.187-195, June 1994.

VAN SANFORD, D.A.; PFEIFFER, T.W.; CORNELIUS, P.L. Selection index based on genetic correlactions among environments. Crop Science, v.33, n.6, p.12441248, Nov./Dec. 1993.

VELLO, N.A. Ampliação da base genética do germoplasma e melhoramento de soja na ESALQ/USP. In: CÂMARA, G.M.S; MARCOS FILHO, J.; OLIVEIRA, E.A.M. , ed. Simpósio sobre cultura e produtividade da soja. Piracicaba: FEALQ, 1992. p.60-81.

VELLO, N.A. Base genética, fontes de genes e métodos de melhoramento para resistência a doenças. In: BANDEL, G.; VELLO, N.A.; MIRANDA FILHO, J.B., ed. ENCONTRO SOBRE TEMAS DE GENÉTICA E MELHORAMENTO, 12., Piracicaba, 1995. Anais. Piracicaba, ESALQ/Departamento de Genética, 1995. p.11-23.

VELLO, N.A.; FEHR, W.R.; BAHRENFUS, J.B. Genetic variability and agronomic performance of soybean populations developed from plant introductions. Crop Science, v.24, n.3, p.511-514, May/June 1984. 
VENCOVSKY, R. Herança quantitativa. In: PATERNIANI, E.; VIEGAS, G.P., ed. Melhoramento e produtividade do milho. Campinas, Fundação Cargill, 1987. cap.5, p.137-214.

VENCOVSKY, R.; BARRIGA, P. Genética biométrica no fitomelhoramento. Ribeirão Preto, Revista Brasileira de Genética, 1992. 486p.

VERNETTI, F.J.; CUNHA, G.M.F. da; ZONTA, E.P. Estabilidade fenotípica de cultivares de soja no sudoeste do Rio Grande do Sul. Pesquisa Agropecuária Brasileira, v.25, n.11, p.1593-1602, Nov. 1990.

WEBER, C.R.; MOORTHY, B.R. Heritable and nonheritable relationship and variability of oil content and agronomic characters in the $F_{2}$ generation of soybean crosses. Agronomy Journal, v.44, n.4, p.202-209, Apr. 1952.

WILCOX, J.R. Breeding soybeans for improved oil quantity and quality. In: SHIBLES, R., ed. WORLD SOYBEAN RESEARCH CONFERENCE, 3., Ames, 1985. Proceedings. Boulder Westview Press, 1985. p.380-386.

WILCOX, J.R.; CAVINS, J.F. Normal and low linolenic acid soybean strains: response to planting date. Crop Science, v.32, n.5, p.1248-1251, Sep./Oct. 1992.

WILCOX, J.R.; SCHAPAUGH, JR. W.T.; BERNARD, R.L.; COOPER, R.L.; FEHR, W.R.; NIEHAUS, M.H. Genetic improvement of soybeans in the midwest. Crop Science, v.19, n.6, p.803-805, Nov./Dec. 1979.

ZAVALA-GARCIA, F.; BRAMEL-COX, P.J.; EASTIN, J.D.; WITT, M.D.; ANDREWS, D.J. Increasing the efficiency of crop selection for unpredictable environments. Crop Science, v.32, p.51-57, 1992. 
ZHANG, J.; HE, Z. Genetic improvement and ecogeographical distribuition of composition of soybean varieties released in Heilongiiang Province of China. Soybean Genetics Newsletter, v.18, p.90-95, Apr. 1991.

ZHOU, X.; ZHU, J. Genotype by Environment interactions of tofu processing traits in soybeans. Soybean Genetics Newsletter, v.21, p.64-69, May 1994.

ZIMBACK, L. Cruzamentos em cadeia entre genótipos adaptados e exóticos de soja com ênfase na produção de óleo. Piracicaba, 1992. 178p. Tese (Doutorado) - Escola Superior de Agricultura "Luiz de Queiroz", Universidade de São Paulo. 
TABELAS 
Tabela 1 Esquema da análise de variância em blocos aumentados para os caracteres avaliados em progênies $F_{6: 3}$ e nas testemunhas comuns. Semeadura em 24 e 25/01/94 nos locais Areão e Anhembi (Piracicaba,SP).

\begin{tabular}{|c|c|c|c|}
\hline FV & GL & QM & $\mathbf{F}$ \\
\hline Blocos (B) & B - 1 & $\mathrm{QM}_{1}$ &.-- \\
\hline Tratamentos ajustados & $\mathbf{R}+\mathbf{T}-\mathbf{1}$ & $\mathrm{QM}_{2}$ & $\mathrm{QM}_{2} / \mathrm{QM}_{6}$ \\
\hline Regulares(R)/B & $(R-1) B$ & $\mathrm{QM}_{3}$ & $\mathrm{QM}_{3} / \mathrm{QM}_{6}$ \\
\hline Testemunhas $(T)$ & $T-1$ & $\mathbf{Q M}_{4}$ & $\mathrm{QM}_{4} / \mathrm{QM}_{6}$ \\
\hline T vs $R / B$ & B & $\mathrm{QM}_{\mathbf{s}}$ & $\mathrm{QM}_{5} / \mathrm{QM}_{6}$ \\
\hline Resíduo Intrabloco & $(B-1)(T-1)$ & $\mathrm{QM}_{6}$ & \\
\hline TOTAL & $\mathrm{R}+\mathrm{BT}-\mathbf{1}$ & & \\
\hline
\end{tabular}


Tabela 2 Esquema da análise de variância por local com progênies $F_{6: 3}$, empregando as médias ajustadas e o erro efetivo médio com as esperanças matemáticas dos quadrados médios. Semeadura em 24 e 25/01/94.

\begin{tabular}{|c|c|c|c|}
\hline FV & QM & $\mathrm{E}(\mathrm{QM})$ & F \\
\hline Repetiçōes & $\mathrm{QM}_{1}$ &.-- & $\mathrm{QM}_{1} / \mathrm{QM}_{11}$ \\
\hline Ciclos $(\mathrm{Ci})$ & $\mathrm{QM}_{2}$ &.-- & $\mathrm{QM}_{2} / \mathrm{QM}_{5}$ \\
\hline Cadeias (Ca)/Ci & $\mathrm{QM}_{3}$ &.-- & $\mathrm{QM}_{3} / \mathrm{QM}_{5}$ \\
\hline Cruzamentos $(\mathrm{Cr}) / \mathrm{Ca} / \mathrm{Ci}$ & $\mathrm{QM}_{4}$ & $\because-$ & $\mathrm{QM}_{4} / \mathrm{QM}_{5}$ \\
\hline Progênies $(\mathrm{P}) / \mathrm{Cr} / \mathrm{Ca} / \mathrm{Ci}$ & $\mathrm{QM}_{s}$ & $\sigma^{2} E+r \sigma^{2} g(P)$ & $\mathrm{QM}_{5} / \mathrm{QM}_{11}$ \\
\hline Precoces (M) & $\mathrm{QM}_{6}$ & $\sigma^{2} E+r \sigma^{2} g(M)$ & $\mathrm{QM}_{6} / \mathrm{QM}_{11}$ \\
\hline Intermediários (I) & $\mathrm{QM}_{7}$ & $\sigma^{2} E+r \sigma^{2} g(I)$ & $\mathrm{QM}_{7} / \mathrm{QM}_{11}$ \\
\hline Tardios (T) & $\mathrm{QM}_{8}$ & $\sigma^{2} E+r \sigma^{2} g(T)$ & $\mathrm{QM}_{8} / \mathrm{QM}_{11}$ \\
\hline Resíduo & $\mathrm{QM}_{9}$ & & \\
\hline Erro Efetivo & $\mathrm{QM}_{10}$ & & \\
\hline Erro Efetivo Médio ${ }^{1}$ & $\mathrm{QM}_{n}$ & $\sigma^{2} \mathrm{E}$ & \\
\hline
\end{tabular}

'Erro efetivo médio : média ponderada entre o resíduo e o erro efetivo;

$\sigma^{2} \mathrm{E}$ : variância ambiental;

$\sigma^{2} g(P)$ : variância genética entre progênies;

$\sigma^{2} \mathrm{~g}(\mathrm{M})$ : variância genética entre precoces;

$\sigma^{2} \mathrm{~g}(\mathrm{I})$ : variância genética entre intermediárias;

$\sigma^{2} \mathrm{~g}(\mathrm{~T})$ : variância genética entre tardias; e

$r$ : número de repetições. 
Tabela 3 Esquema da análise conjunta envolvendo dois locais (Areão e Anhembi) e progênies $F_{6: 3}$ de soja, empregando o erro efetivo médio geral com as esperanças matemáticas. Semeadura em 24 e 25/01/94.

\begin{tabular}{|c|c|c|c|}
\hline FV & $\mathrm{QM}$ & $\mathrm{E}(\mathrm{QM})$ & $\overline{\mathrm{F}}$ \\
\hline Locais (L) & $\mathrm{QM}_{1}$ & $\because-$ & $\mathrm{QM}_{1} / \mathrm{QM}_{2}$ \\
\hline Repetiçōes (R)/L & $\mathrm{QM}_{2}$ &.-- & $\mathrm{QM}_{2} / \mathrm{QM}_{17}$ \\
\hline Ciclos (Ci) & $\mathrm{QM}_{3}$ & $-\because-$ & $\mathrm{QM}_{3} / \mathrm{QM}_{10}$ \\
\hline Cadeias $(\mathrm{Ca}) / \mathrm{Ci}$ & $\mathrm{QM}_{4}$ &.-- & $\mathrm{QM}_{4} / \mathrm{QM}_{11}$ \\
\hline Cruzamentos $(\mathrm{Cr}) / \mathrm{Ca} / \mathrm{Ci}$ & $\mathrm{QM}_{\mathrm{s}}$ & $-\because-$ & $\mathrm{QM}_{5} / \mathrm{QM}_{12}$ \\
\hline Progênies $(\mathrm{P}) / \mathrm{Cr} / \mathrm{Ca} / \mathrm{Ci}$ & $\mathrm{QM}_{6}$ & $\sigma^{2} E+r \sigma^{2} L x P+r l \sigma^{2} g(P)$ & $\mathrm{QM}_{6} / \mathrm{QM}_{13}$ \\
\hline Prococes (M) & $\mathrm{QM}_{7}$ & $\sigma^{2} \mathrm{E}+\mathrm{r} \sigma^{2} \mathrm{LxM}+\mathrm{rl} \sigma^{2} \mathrm{~g}(\mathrm{M})$ & $\mathrm{QM}_{7} / \mathrm{QM}_{14}$ \\
\hline Intermediárias (I) & $\mathrm{QM}_{8}$ & $\sigma^{2} \mathrm{E}+\mathbf{r} \sigma^{2} \mathrm{LxI}+\mathrm{rl} \sigma^{2} \mathrm{~g}(\mathrm{I})$ & $\mathrm{QM}_{8} / \mathrm{QM}_{15}$ \\
\hline Tardias (T) & $\mathrm{QM}_{9}$ & $\sigma^{2} E+r \sigma^{2} L x T+r l \sigma^{2} g(T)$ & $\mathrm{QM}_{9} / \mathrm{QM}_{16}$ \\
\hline $\mathrm{L} \times \mathrm{Ci}^{-}$ & $\mathrm{QM}_{10}$ & $\because-$ & $\mathrm{QM}_{10} / \mathrm{QM}_{17}$ \\
\hline $\mathrm{L} \times \mathrm{Ca} / \mathrm{Ci}$ & $\mathrm{QM}_{11}$ &.-- & $\mathrm{QM}_{11} / \mathrm{QM}_{17}$ \\
\hline $\mathrm{L} \times \mathrm{Cr} / \mathrm{Ca} / \mathrm{Ci}$ & $\mathrm{QM}_{12}$ & $-\because-$ & $\mathrm{QM}_{12} / \mathrm{QM}_{17}$ \\
\hline $\mathrm{L} \times \mathrm{P} / \mathrm{Cr} / \mathrm{Ca} / \mathrm{Ci}$ & $\mathrm{QM}_{13}$ & $\sigma^{2} E+r \sigma^{2} L x P$ & $\mathrm{QM}_{13} / \mathrm{QM}_{17}$ \\
\hline $\mathrm{L} \times \mathrm{M}$ & $\mathrm{QM}_{14}$ & $\sigma^{2} \mathrm{E}+\mathrm{r} \sigma^{2} \mathrm{LxM}$ & $\mathrm{QM}_{14} / \mathrm{QM}_{17}$ \\
\hline$L \times I$ & $\mathrm{QM}_{15}$ & $\sigma^{2} E+r \sigma^{2} L x I$ & $\mathbf{Q M}_{15} / \mathbf{Q M}_{17}$ \\
\hline $\mathrm{L} \times \mathrm{T}$ & $\mathrm{QM}_{16}$ & $\sigma^{2} E+r \sigma^{2} L x T$ & $\mathrm{QM}_{16} / \mathrm{QM}_{17}$ \\
\hline Erro Efetivo Médio Geral ${ }^{1}$ & $\mathrm{QM}_{17}$ & $\sigma^{2} \mathrm{E}$ & \\
\hline
\end{tabular}

'Obtido da média aritmética entre os erros efetivos médios da análise individual;

$\sigma_{\text {LxP }}^{2}$ : variância da interação locais x progênies;

$\sigma^{2} g(P)$ : variância genética entre progênies;

$\sigma^{2} \mathbf{g}(\mathrm{M})$ : variância genética entre precoces;

$\sigma^{2} g(I)$ : variância genética entre intermediárias;

$\sigma^{2} \mathbf{g}(\mathrm{T})$ : variância genética entre tardias;

$\mathbf{r}:$ número de repetições; $\mathrm{e}$

1 : número de locais. 
Tabela 4 Esquema da análise de variância em blocos incompletos com testemunhas comuns por local, em progênies $F_{7: 3}$ de soja, com as esperanças dos quadrados médios. Semeadura em 22 e 28/10/94.

\begin{tabular}{llll}
\hline \hline \multicolumn{1}{c}{$\mathrm{FV}$} & $\mathrm{QM}$ & $\mathrm{E}(\mathrm{QM})$ & $\mathrm{F}$ \\
\hline Experimentos (G) & $\mathrm{QM}_{1}$ &.-- & $\mathrm{QM}_{1} / \mathrm{QM}_{2}$ \\
Repetições (R)/G & $\mathrm{QM}_{2}$ &.-- & $\mathrm{QM}_{2} / \mathrm{QM}_{14}$ \\
Tratamentos ajustados (Z) & $\mathrm{QM}_{3}$ &.-- & $\mathrm{QM}_{3} / \mathrm{QM}_{14}$ \\
- Ciclos (Ci) & $\mathrm{QM}_{4}$ &.-- & $\mathrm{QM}_{4} / \mathrm{QM}_{7}$ \\
- Cadeias (Ca)/Ci & $\mathrm{QM}_{5}$ &.-- & $\mathrm{QM}_{5} / \mathrm{QM}_{7}$ \\
- Cruzamentos (Cr)/Ca/Ci & $\mathrm{QM}_{6}$ &.-- & $\mathrm{QM}_{6} / \mathrm{QM}_{7}$ \\
- Progênies (P)/Cr/Ca/Ci & $\mathrm{QM}_{7}$ & $\sigma^{2} \mathrm{E}+\mathrm{r} \sigma^{2} \mathrm{~g}(\mathrm{P})$ & $\mathrm{QM}_{7} / \mathrm{QM}_{14}$ \\
* Precoces (M) & $\mathrm{QM}_{8}$ & $\sigma^{2} \mathrm{E}+\mathrm{r} \sigma^{2} \mathrm{~g}(\mathrm{M})$ & $\mathrm{QM}_{8} / \mathrm{QM}_{14}$ \\
$*$ Intermediárias (I) & $\mathrm{QM}_{9}$ & $\sigma^{2} \mathrm{E}+\mathrm{r} \sigma^{2} \mathrm{~g}(\mathrm{I})$ & $\mathrm{QM}_{9} / \mathrm{QM}_{14}$ \\
$*$ Tardias (T) & $\mathrm{QM}_{10}$ & $\sigma^{2} \mathrm{E}+\mathrm{r} \sigma^{2} \mathrm{~g}(\mathrm{~T})$ & $\mathrm{QM}_{10} / \mathrm{QM}_{14}$ \\
- Testemunhas (C) & $\mathrm{QM}_{11}$ &.-- & $\mathrm{QM}_{11} / \mathrm{QM}_{14}$ \\
- P vs C & $\mathrm{QM}_{12}$ &.-- & $\mathrm{QM}_{12} / \mathrm{QM}_{14}$ \\
G x C & $\mathrm{QM}_{13}$ &.-- & $\mathrm{QM}_{13} / \mathrm{QM}_{14}$ \\
Erro & $\mathrm{QM}_{14}$ & $\sigma^{2} \mathrm{E}$ & \\
\hline \hline
\end{tabular}

$\sigma^{2} \mathrm{E}$ : variância ambiental;

$\sigma^{2} g(p)$ : variância genética entre progênies dentro de cruzamentos, cadeias e ciclos de maturidade; r : número de repetições;

Empregando a simbologia de Pimentel Gomes (1990) onde: g : número de experimentos; z : número de tratamentos regulares; e c : número de tratamentos comuns, num total de $\mathrm{V}=\mathrm{gz}+\mathrm{c}$ tratamentos. Cada experimento ensaiado em $\mathrm{r}$ repetições de $\mathrm{K}=\mathrm{Z}+\mathrm{C}$ parcelas. 
Tabela 5 Esquema da análise conjunta de variância através de dois locais (Areão e Anhembi) e duas épocas de semeadura em progênies $F_{6: 3}$ e $F_{7: 3}$ de soja. Semeaduras em 24 e 25/01/94 em blocos aumentados e em 22 e 28/10/94, em látice.

\begin{tabular}{|c|c|c|c|}
\hline FV & $\mathbf{Q M}$ & $\mathrm{E}(\mathrm{QM})^{*}$ & $\mathrm{~F}^{*}$ \\
\hline Locais (L) & $\mathbf{Q M}_{1}$ & $-\because-$ &.-- \\
\hline Epocas (A) & $\mathbf{Q M}_{2}$ &.- &.-- \\
\hline$L \times A$ & $\mathrm{QM}_{3}$ &.-- &.-- \\
\hline Repetições (R)/L/A & $\mathrm{QM}_{4}$ &.-- &.-- \\
\hline Cruzamentos (C) & $\mathrm{QM}_{5}$ &.-- &.-- \\
\hline Progênies (P)/C & $\mathrm{QM}_{6}$ & $\sigma^{2} E+\operatorname{ra} \sigma^{2} L x P+\operatorname{rla} \sigma^{2} g(P)$ & $\mathrm{QM}_{6} / \mathrm{QM}_{13}$ \\
\hline - Precoces (M) & $\mathrm{QM}_{7}$ & $\sigma^{2} \mathrm{E}+\mathrm{ra} \sigma^{2} \mathrm{LxM}+\mathrm{rla}^{2} \mathrm{~g}(\mathrm{M})$ & $\mathrm{QM}_{7} / \mathrm{QM}_{14}$ \\
\hline -Intermediárias (I) & $\mathrm{QM}_{8}$ & $\sigma^{2} E+r a \sigma^{2} L x I+r l a \sigma^{2} g(I)$ & $\mathrm{QM}_{8} / \mathrm{QM}_{15}$ \\
\hline - Tardias $(\mathrm{T})$ & $\mathrm{QM}_{9}$ & $\sigma^{2} \mathrm{E}+\mathrm{ra} \sigma^{2} \mathrm{LxT}+\operatorname{rla} \sigma^{2} \mathrm{~g}(\mathrm{~T})$ & $\mathrm{QM}_{9} / \mathrm{QM}_{16}$ \\
\hline$L \times C$ & $\mathrm{QM}_{10}$ &.-- &.-- \\
\hline$A \times C$ & $\mathbf{Q M}_{11}$ & $\because-$ &.-- \\
\hline LxA $\times C$ & $\mathbf{Q M}_{12}$ & $\because-$ &.-- \\
\hline $\mathrm{L} \times \mathrm{P} / \mathrm{c}$ & $\mathrm{QM}_{13}$ & $\sigma^{2} E+r a \sigma^{2} L x P$ & $\mathrm{QM}_{13} / \mathrm{QM}_{26}$ \\
\hline$-\mathbf{L} \times \mathbf{M}$ & $\mathbf{Q M}_{14}$ & $\sigma^{2} E+r a \sigma^{2} L x M$ & $\mathrm{QM}_{14} / \mathrm{QM}_{26}$ \\
\hline$-\mathrm{L} \times \mathrm{I}$ & $\mathrm{QM}_{15}$ & $\sigma^{2} E+r a \sigma^{2} L x I$ & $\mathrm{QM}_{15} / \mathrm{QM}_{26}$ \\
\hline$-L \times T$ & $\mathrm{QM}_{16}$ & $\sigma^{2} E+r a \sigma^{2} L x T$ & $\mathrm{QM}_{16} / \mathrm{QM}_{26}$ \\
\hline $\mathrm{A} \times \mathrm{P} / \mathrm{c}$ & $\mathbf{Q M}_{17}$ & $\sigma^{2} E+(a / a-1) r \sigma^{2} L x A x P+(a / a-1) r l \sigma^{2} A x P$ & $\mathrm{QM}_{17} / \mathrm{QM}_{21}$ \\
\hline$-\mathbf{A} \times \mathbf{M}$ & $\mathrm{QM}_{18}$ & $\sigma^{2} E+(a / a-1) r \sigma^{2} L x A x M+(a / a-1) r l \sigma^{2} A x M$ & $\mathrm{QM}_{18} / \mathrm{QM}_{22}$ \\
\hline$-A \times I$ & $\mathrm{QM}_{19}$ & $\sigma^{2} E+(a / a-1) r \sigma^{2} \operatorname{LxAxI}+(a / a-1) r l \sigma^{2} A x I$ & $\mathrm{QM}_{19} / \mathrm{QM}_{23}$ \\
\hline$-A \times T$ & $\mathrm{QM}_{20}$ & $\sigma^{2} E+(a / a-1) r \sigma^{2} L x A x T+(a / a-1) r l \sigma^{2} A x T$ & $\mathrm{QM}_{20} / \mathrm{QM}_{24}$ \\
\hline $\mathrm{L} \times \mathrm{A} \times \mathrm{P} / \mathrm{c}$ & $\mathrm{QM}_{21}$ & $\sigma^{2} E+(a / a-1) r \sigma^{2} L x A x P$ & $\mathrm{QM}_{21} / \mathrm{QM}_{26}$ \\
\hline$-\mathrm{L} \times \mathrm{A} \times \mathrm{M}$ & $\mathrm{QM}_{22}$ & $\sigma^{2} E+(a / a-1) r \sigma^{2} \operatorname{LxAxM}$ & $\mathrm{QM}_{22} / \mathrm{QM}_{26}$ \\
\hline$-L \times A \times I$ & $\mathrm{QM}_{23}$ & $\sigma^{2} E+(a / a-1) r \sigma^{2} \operatorname{LxAxI}$ & $\mathrm{QM}_{23} / \mathrm{QM}_{26}$ \\
\hline$-\mathrm{L} \times \mathrm{A} \times \mathrm{T}$ & $\mathrm{QM}_{24}$ & $\sigma^{2} \mathrm{E}+(\mathrm{a} / \mathrm{a}-1) \mathrm{r} \sigma^{2} \operatorname{LxAxT}$ & $\mathrm{QM}_{24} / \mathrm{QM}_{26}$ \\
\hline Resíduo & $\mathrm{QM}_{25}$ & $\because-$ & \\
\hline $\begin{array}{l}\text { Erro Médio } \\
\text { Conjunto Geral }\end{array}$ & $\mathbf{Q M}_{26}$ & $\sigma^{2} \mathrm{E}$ & \\
\hline
\end{tabular}

$\sigma^{2} L x A x P$ : variância da interação locais $x$ épocas $x$ progênies;

$\sigma^{2} L x P$ : variância da interação locais $x$ progênies;

$\sigma^{2} \mathrm{AxP}$ : variância da interação épocas $\mathrm{x}$ progênies;

$r$ : número de repetições.

1 : número de locais; e

a : número de épocas.

* segundo Vencovsky \& Barriga, 1992. 


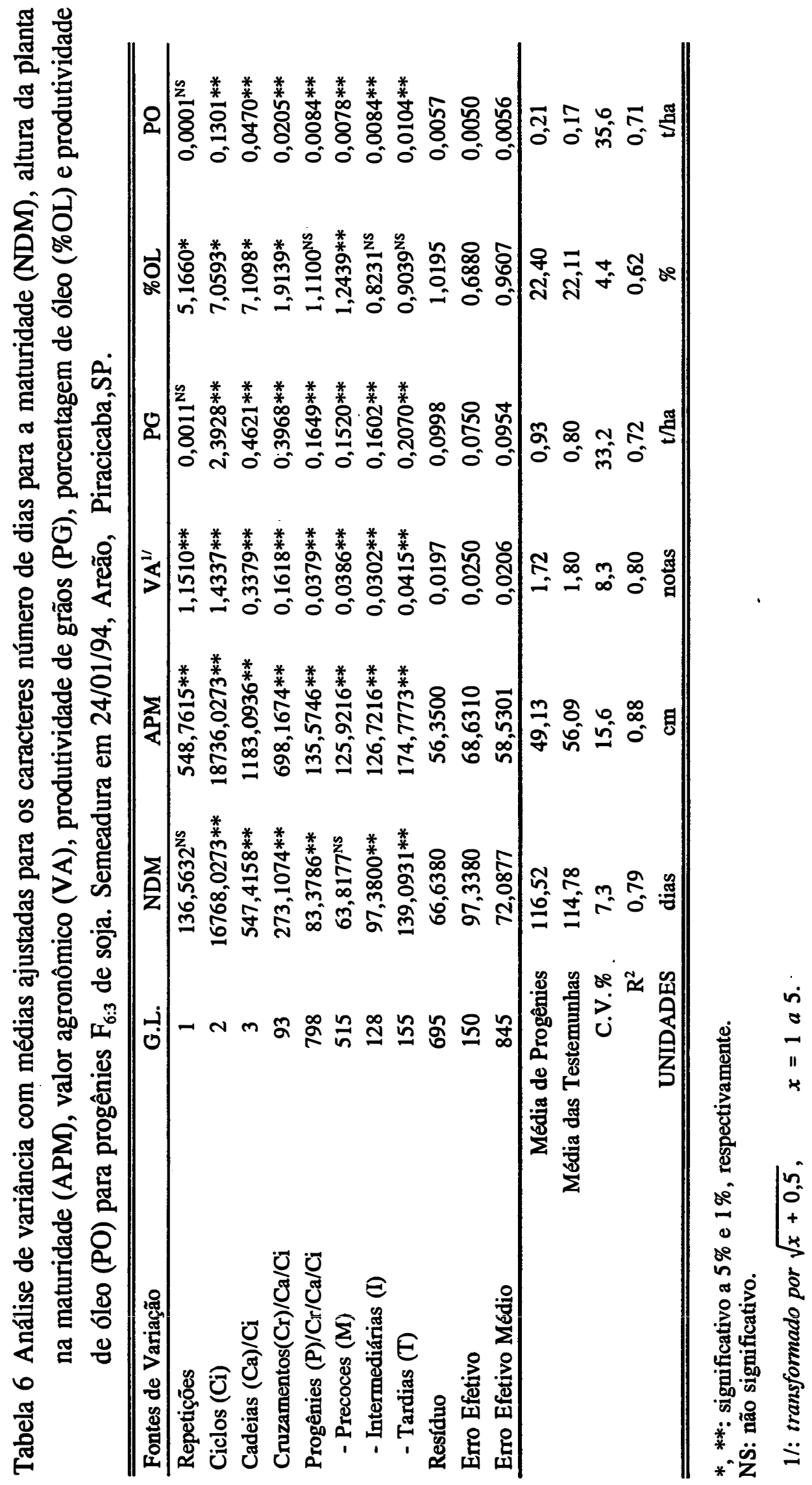




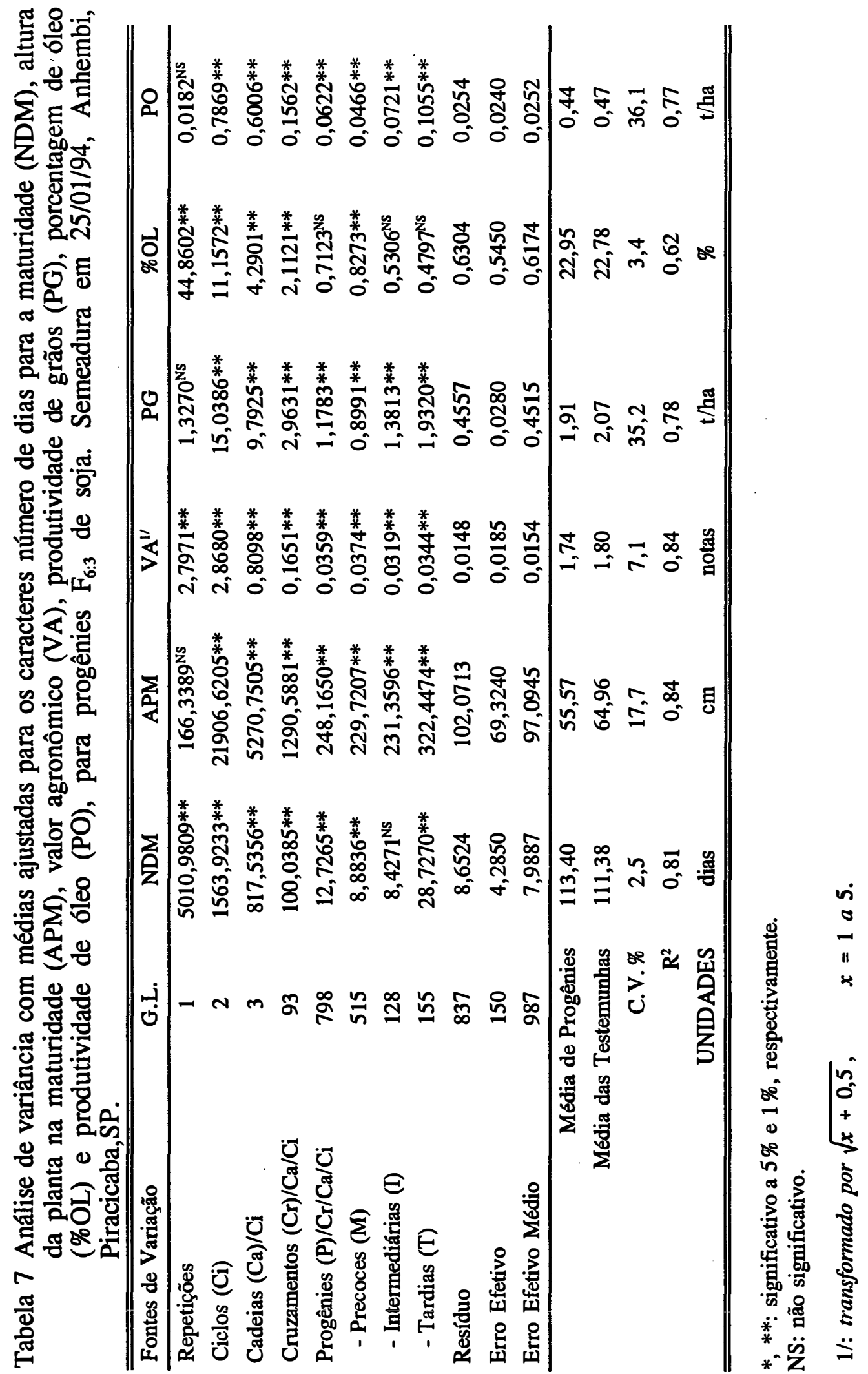




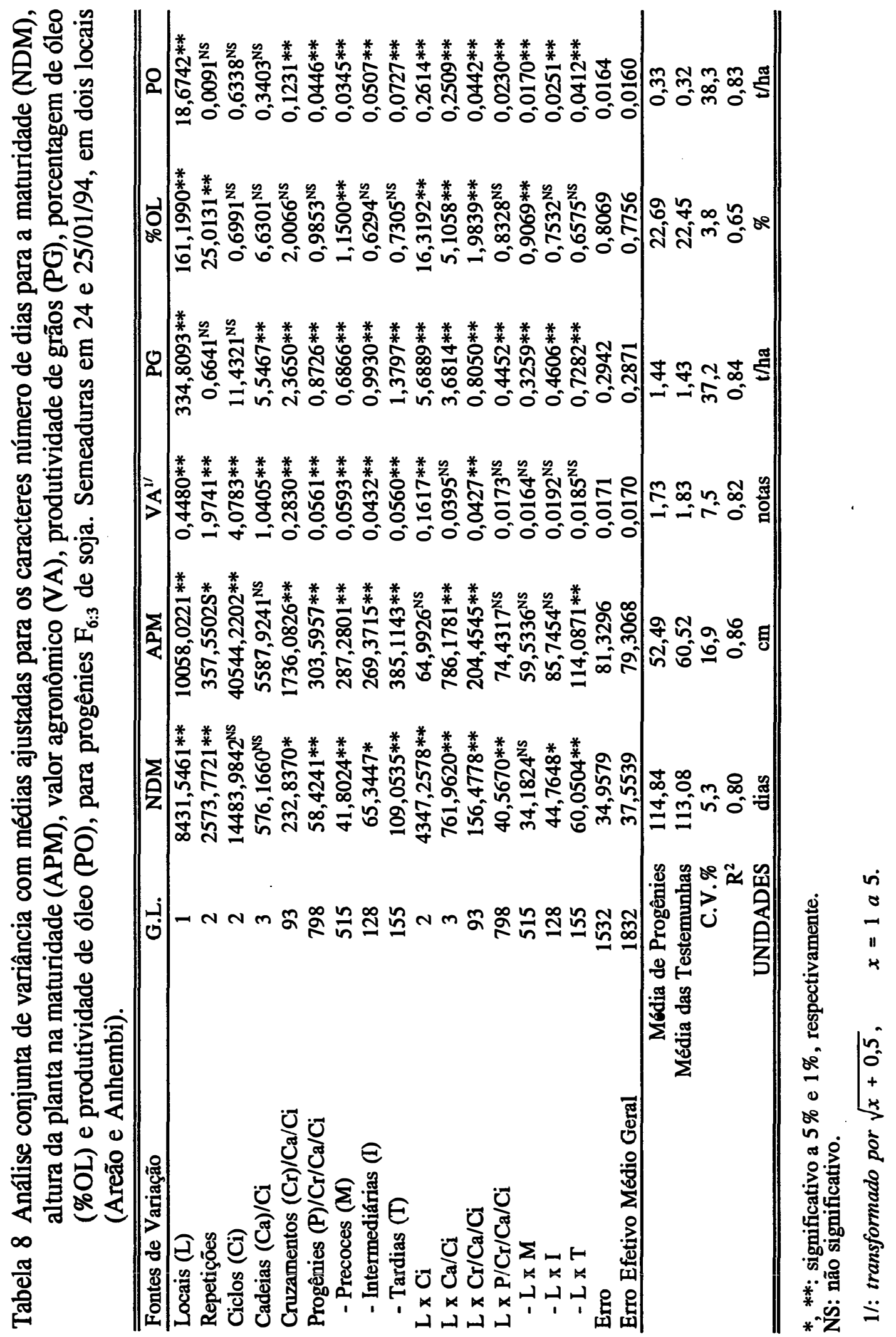




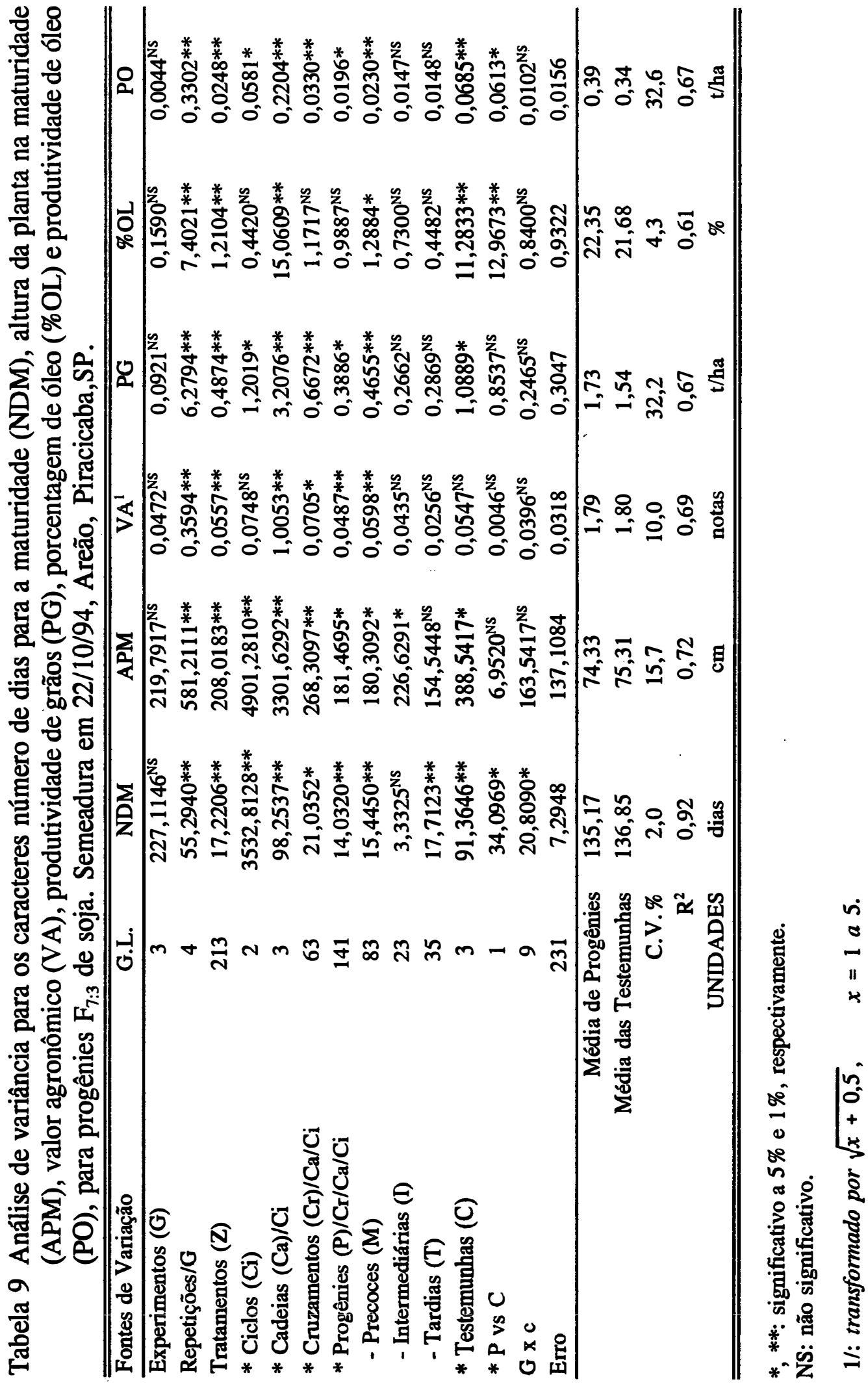




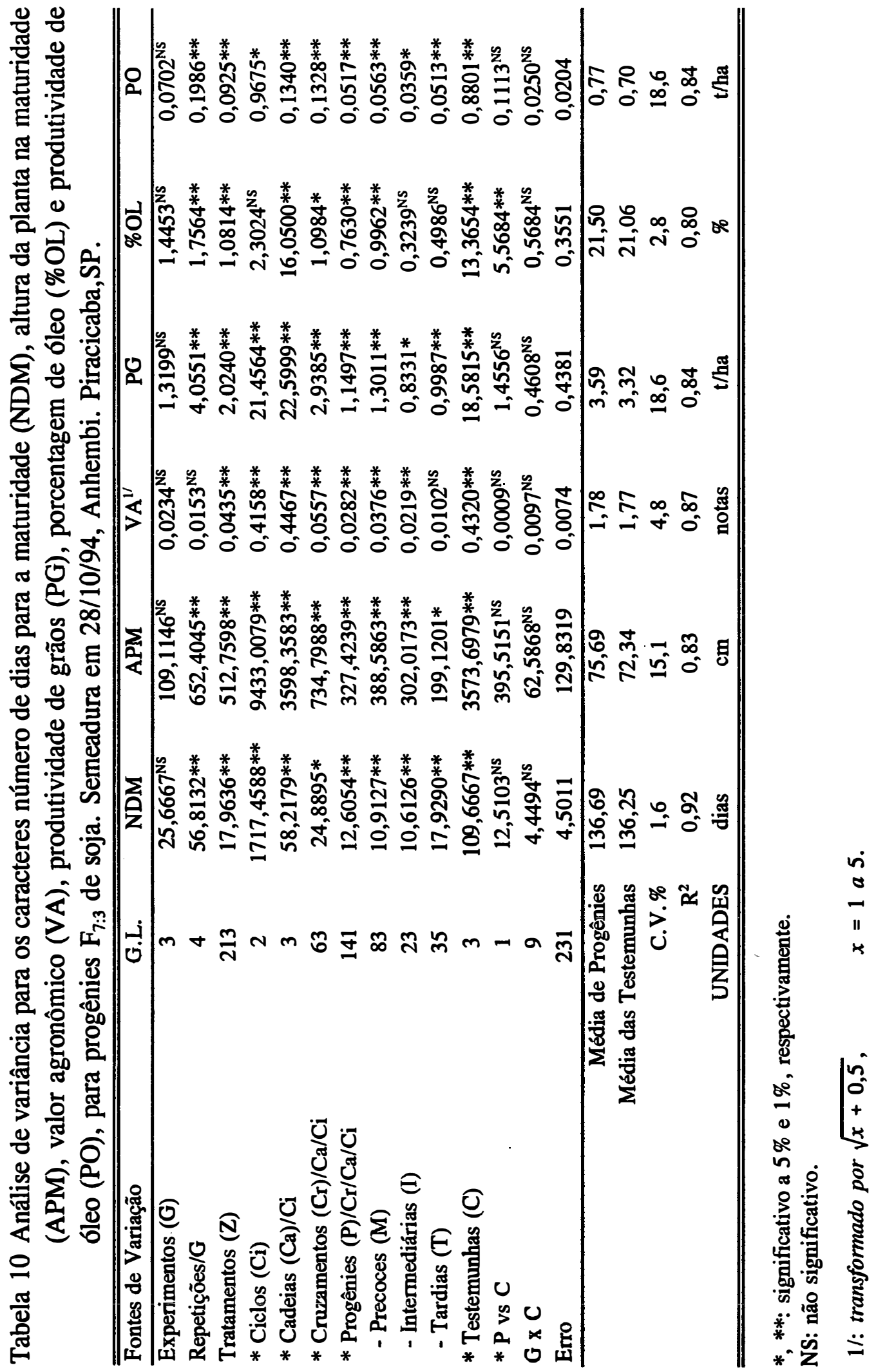




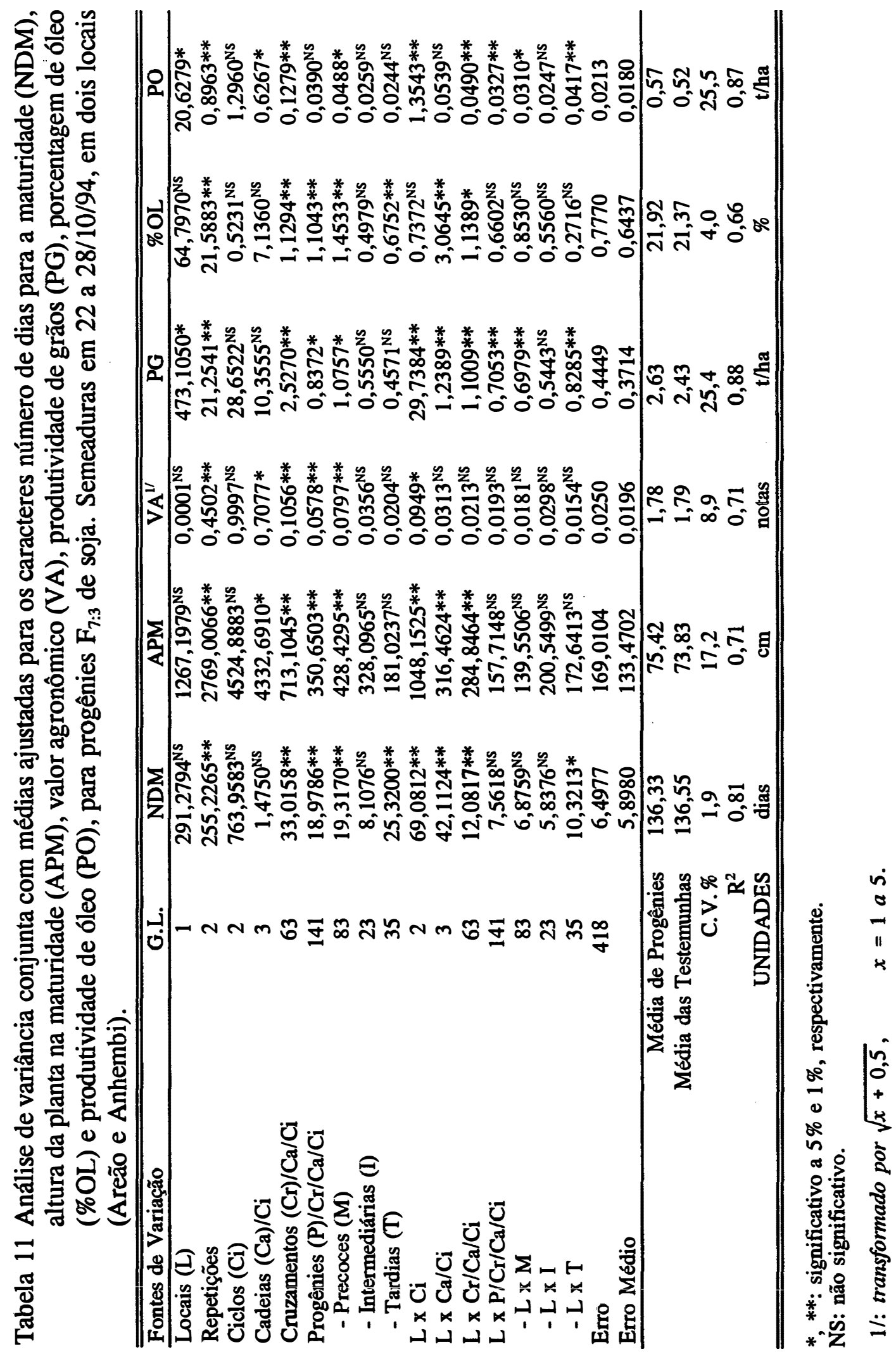


Tabela 12 Número de dias para a maturidade (NDM). Estimativas de médias ajustadas $(\overline{\mathrm{x}})$, variâncias fenotípicas $\left(\mathrm{S}^{2}\right)$ e intervalo de variação (iv) de cruzamentos em cadeia. Progênies $F_{6: 3}$ (semeaduras em 24 e 25/01/94) e $F_{7: 3}$ (semeaduras em 22 e 28/10/94) de soja avaliadas em dois locais (Areão e Anhembi).

\begin{tabular}{|c|c|c|c|c|c|c|c|c|c|c|c|c|}
\hline \multirow[t]{3}{*}{ cruz $^{1 /}$} & \multicolumn{6}{|c|}{ Geracão $F_{0.3}$} & \multicolumn{6}{|c|}{ Geracão $F_{7.3}$} \\
\hline & \multicolumn{3}{|c|}{ Areảo } & \multicolumn{3}{|c|}{ Anhembi } & \multicolumn{3}{|c|}{ Areão } & \multicolumn{3}{|c|}{ Anhembi } \\
\hline & $\overline{\mathbf{x}}$ & $S^{2}$ & iv & $\overline{\mathbf{x}}$ & $S^{2}$ & iv & $\overline{\mathbf{x}}$ & $S^{2}$ & iv & $\overline{\mathbf{X}}$ & $S^{2}$ & iv \\
\hline $1 \times 2$ & 114 & 74 & $102-115$ & 113 & 20 & $104-121$ & 132 & 25 & $128-144$ & 135 & 10 & $130-142$ \\
\hline $2 \times 3$ & 112 & 96 & $103-147$ & 113 & 17 & $106-121$ & 129 & 1 & $128-130$ & 136 & 10 & $132-140$ \\
\hline $3 \times 4$ & 114 & 97 & $102-104$ & 111 & 5 & $108-117$ & 135 & 42 & $128-144$ & 138 & 31 & $132-152$ \\
\hline $4 \times 5$ & 110 & 58 & $103-124$ & 112 & 10 & $108-122$ & 133 & 33 & $128-138$ & 135 & 15 & $132-140$ \\
\hline $5 x$ & 112 & 104 & $101-147$ & 118 & 16 & $109-123$ & 129 & 1 & $128-130$ & 135 & 7 & $132-138$ \\
\hline $6 x^{\prime}$ & 109 & 21 & $106-128$ & 117 & 22 & $110-123$ & 129 & 1 & $128-130$ & 135 & 4 & $132-138$ \\
\hline $7 \mathrm{x}$ & 108 & 6 & $106-115$ & 118 & 21 & $113-123$ & 129 & 2 & $128-130$ & 135 & 18 & $132-138$ \\
\hline $8 x$ & 113 & 98 & $107-145$ & 111 & 9 & $110-123$ & 129 & 2 & $128-130$ & 130 & 0 & $130-130$ \\
\hline & 111 & 88 & $106-147$ & 114 & 6 & $110-119$ & 128 & 0 & $128-128$ & 134 & 1 & $134-135$ \\
\hline 10 & 110 & 102 & $93-1<$ & 114 & 18 & -128 & 133 & 44 & $128-147$ & 13 & 8 & 140 \\
\hline & 109 & 35 & $102-126$ & 114 & 10 & & 129 & 3 & $128-134$ & 13 & 8 & \\
\hline & 113 & 96 & $102-147$ & 112 & 12 & -121 & 128 & 0 & $128-128$ & 13 & 10 & \\
\hline & 131 & 116 & $104-145$ & 122 & 36 & & 141 & 17 & & 14 & 32 & \\
\hline & & 98 & $105-145$ & 115 & 56 & & 132 & 38 & $128-142$ & 13 & 20 & \\
\hline & 112 & 90 & 105 & 111 & 8 & & 129 & 2 & -130 & 13 & 0 & \\
\hline & 114 & 103 & $104-155$ & 114 & 13 & & 136 & 8 & $134-138$ & 14 & 0 & \\
\hline $17 \mathrm{x}$ & 112 & 34 & $104-125$ & 115 & 6 & & 128 & 0 & $128-128$ & 13 & 32 & \\
\hline & 110 & 58 & $96-13$ & 115 & 9 & -121 & 129 & 1 & -130 & 13 & 3 & \\
\hline & 11 & 132 & $102-137$ & 116 & 16 & -126 & 134 & 35 & 140 & 140 & 24 & \\
\hline $20 \mathrm{x}$ & 117 & 82 & $97-136$ & 112 & 15 & -127 & 136 & 36 & 147 & 137 & 9 & -142 \\
\hline $21 x^{2}$ & & 20 & 103- & 111 & 9 & & 135 & 36 & -142 & 138 & 1 & \\
\hline & 115 & 78 & 104 & 114 & 33 & & 139 & 2 & $138-140$ & 14 & 32 & \\
\hline & & 76 & & 113 & 21 & & 134 & 21 & & 13 & 1 & \\
\hline & 1 & 49 & & 112 & 15 & & 132 & 27 & & 134 & 22 & \\
\hline & 11 & 38 & $102-123$ & 112 & 13 & -118 & 131 & 12 & 128 & 131 & 1 & \\
\hline & 1. & 50 & & 114 & 19 & & 132 & 9 & & 13 & 3 & \\
\hline $27 x^{\prime}$ & 112 & 41 & & 111 & 12 & 10 & 131 & 19 & -144 & 13 & 12 & \\
\hline & & 182 & & 114 & 39 & & 129 & 1 & -130 & 13 & 3 & \\
\hline & 118 & 119 & & 113 & 26 & & 134 & 29 & & 13 & 18 & \\
\hline & 108 & 51 & & 111 & 9 & 10 & 131 & 18 & -138 & 13 & 18 & \\
\hline & 126 & 69 & & 114 & 20 & & 139 & 17 & 13 & 13 & 15 & \\
\hline & 129 & 77 & & 117 & 40 & & 143 & 32 & & 145 & 34 & \\
\hline & 127 & 120 & 10 & 114 & 23 & & 143 & 40 & -155 & 14 & 2 & \\
\hline & 123 & 82 & & 111 & 12 & & 136 & 32 & $12 \varepsilon$ & 13 & 3 & \\
\hline & 120 & 100 & & 113 & 21 & & 138 & 13 & & 13 & 20 & \\
\hline & 130 & 137 & & 115 & 20 & 10 & 140 & 54 & -155 & 13 & 23 & \\
\hline & 12 & 177 & & 112 & 17 & & 139 & 27 & & 13 & 16 & \\
\hline & 111 & 129 & & 110 & 9 & & 131 & 11 & & 13 & 18 & \\
\hline & 11 & 146 & & 11 & 9 & & 141 & 12 & & 14 & 2 & \\
\hline & & 124 & & 112 & 6 & $108-115$ & 135 & 15 & $130-138$ & 137 & 16 & \\
\hline Bossier & 111 & - & $101-120$ & 112 & - & $106-118$ & 135 & - & $128-142$ & 134 & - & $130-138$ \\
\hline & & & & 113 & - & & 14 & 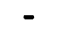 & & 14 & & \\
\hline & 11 & - & $100-140$ & 111 & - & $106-$ & 136 & - & $128-147$ & 13 & - & -138 \\
\hline & 110 & $=$ & $100-122$ & 109 & - & $106-114$ & 135 & $=$ & $128-146$ & 132 & $=$ & $128-136$ \\
\hline & 117 & - & - & 113 & - & - & 135 & - & - & 137 & - & - \\
\hline & & - & & & & & 137 & & & & & \\
\hline
\end{tabular}

1/: Os cruzamentos de $1 \times 2$ até $20 \times 1$ pertencem à cadeia de cruzamentos mista (exótico x adaptado) e os cruzamentos de $21 \times 22$ até $40 \times 21$ à cadeia de cruzamentos adaptada (adaptado x adaptado). Os números 1,2, .., 40 referem-se aos parentais identificados no Apêndice 3 . 
Tabela 13 Altura da planta na maturidade (APM). Estimativas de médias ajustadas $\left(\bar{x} \mathrm{em} \mathrm{cm}\right.$ ), variâncias fenotípicas $\left(S^{2}\right)$ e intervalo de variação (iv) de cruzamentos em cadeia. Progênies $F_{6: 3}$ (semeaduras em 24 e 25/01/94) e $F_{7: 3}$ (semeaduras em 22 e 28/10/94) de soja avaliadas em dois locais (Areão e Anhembi).

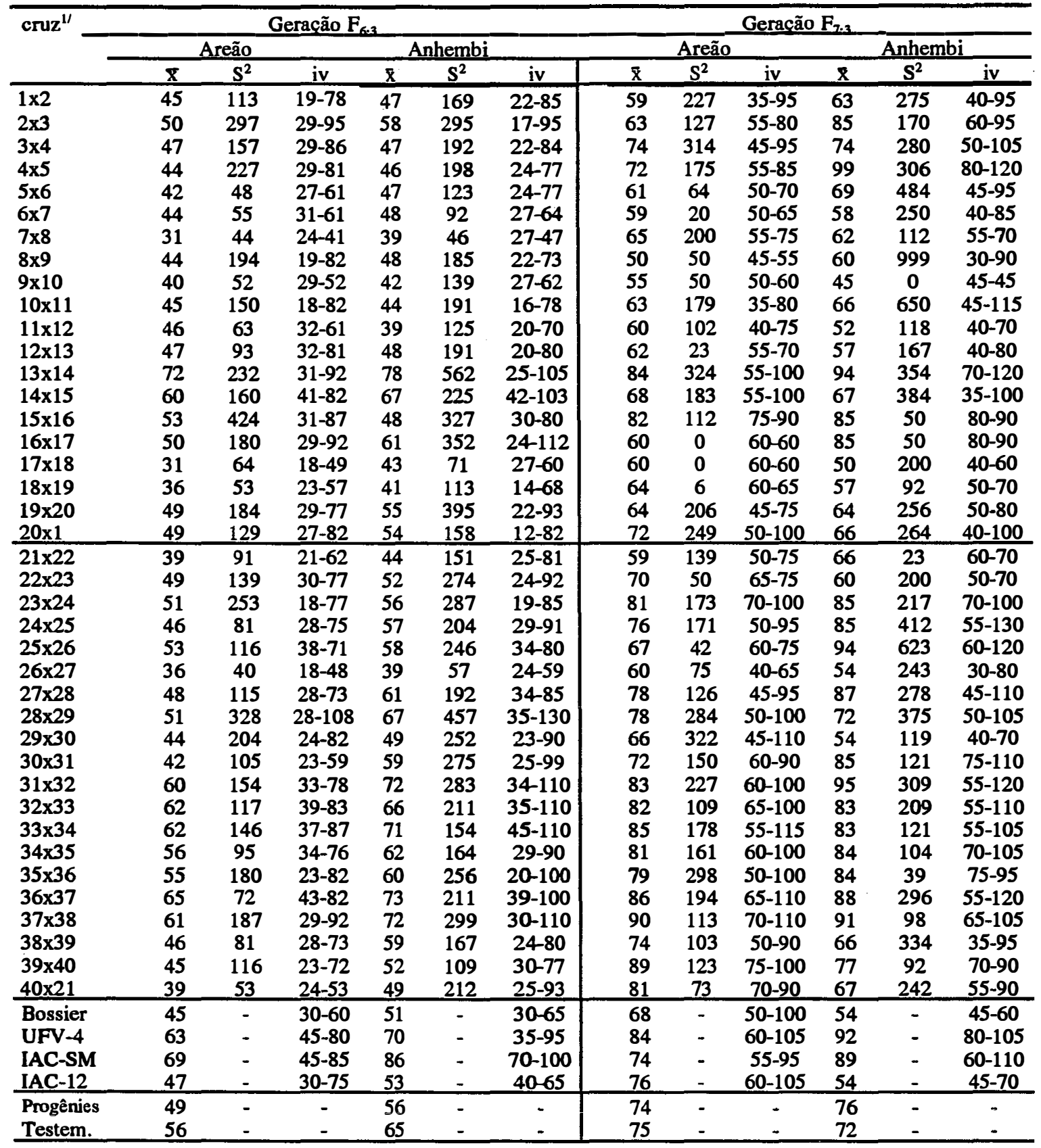

": Os cruzamentos de $1 \times 2$ até $20 \times 1$ pertencem à cadeia de cruzamentos mista (exótico $\times$ adaptado) e os cruzamentos de $21 \times 22$ até 40 × 21 à cadeia de cruzamentos adaptada (adaptado x adaptado). Os números 1, 2, .., 40 referem-se aos parentais identificados no Apêndice 3. 
Tabela 14 Valor agronômico (VA). Estimativas de médias ajustadas ( $\bar{x})$, variâncias fenotípicas $\left(S^{2}\right)$ e intervalo de variação (iv) de cruzamentos em cadeia. Progênies $F_{6: 3}$ (semeaduras em 24 e 25/01/94) e $F_{7: 3}$ (semeaduras em 22 e 28/10/94) de soja avaliadas em dois locais (Areão e Anhembi).

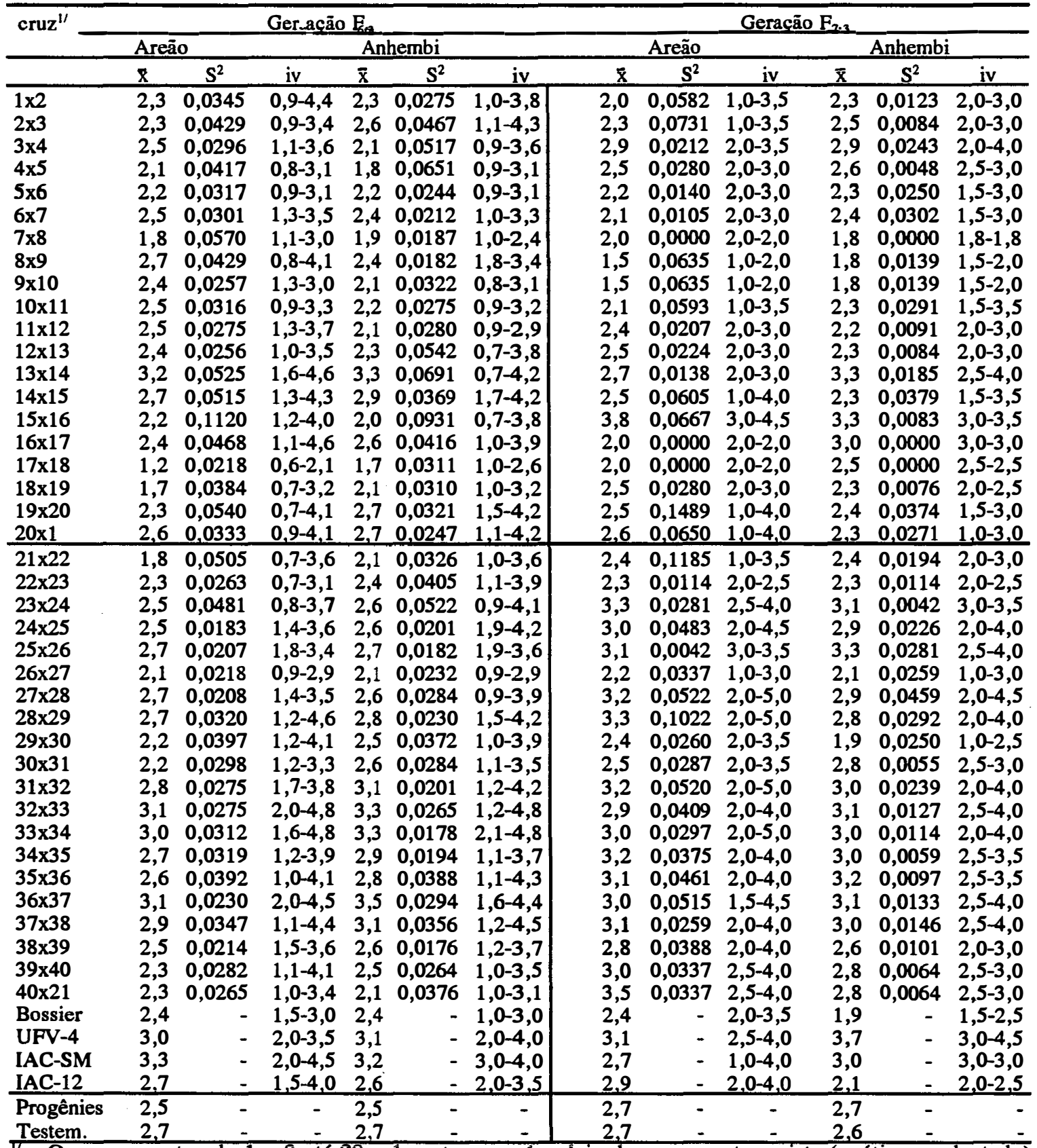

"T: Os cruzamentos de 1 × 2 até $20 \times 1$ pertencem á cadeia de cruzamentos mista (exótico $\times$ adaptado) e os cruzamentos de $21 \times 22$ até 40 × 21 á cadeia de cruzamentos adaptada (adaptado x adaptado). Os números 1, 2, .., 40 referem-se aos parentais identificados no Apêndice 3 . 
Tabela 15 Produtividade de grãos (PG). Estimativas de médias ajustadas ( $\bar{x}$ em t/ha), variâncias fenotípicas $\left(S^{2}\right)$ e intervalo de variação (iv) de cruzamentos em cadeia. Progênies $\mathrm{F}_{6: 3}$ (semeaduras em 24 e 25/01/94) e $\mathrm{F}_{7: 3}$ (semeaduras em 22 e 28/10/94) de soja avaliadas em dois locais (Areão e Anhembi).

\begin{tabular}{|c|c|c|c|c|c|c|c|c|c|c|c|c|}
\hline \multirow[t]{3}{*}{$\mathrm{cruz}^{1 /}$} & \multicolumn{6}{|c|}{ Geracão $F_{6 . a}$} & \multicolumn{6}{|c|}{ Geracão $F_{7.3}$} \\
\hline & \multicolumn{3}{|c|}{ Areão } & \multicolumn{3}{|c|}{ Anhembi } & \multicolumn{3}{|c|}{ Areão } & \multicolumn{3}{|c|}{ Anhembi } \\
\hline & $\overline{\mathbf{x}}$ & $\mathbf{S}^{2}$ & iv & $\overline{\mathbf{x}}$ & $\mathrm{S}^{2}$ & iv & $\overline{\mathbf{x}}$ & $\mathrm{S}^{2}$ & iv & $\overline{\mathbf{x}}$ & $S^{2}$ & iv \\
\hline $1 \times 2$ & 0,86 & 0,1171 & $0,2-1,7$ & 1,55 & 0,7148 & $0,1-3,7$ & 1,57 & 0,4007 & $0,7-2,8$ & 2,98 & 0,7193 & $1,7-4,5$ \\
\hline $2 \times 3$ & 0,96 & 0,2639 & $0,2-2,6$ & 1,65 & 1,1311 & $0,1-5,0$ & 1,06 & 0,2903 & $0,6-1,8$ & 2,18 & 0,6459 & $1,1-3,4$ \\
\hline $3 \times 4$ & 0,98 & 0,2122 & $0,3-2,0$ & 1,61 & 0,9175 & $0,5-4,6$ & 1,88 & 0,5598 & $0,7-3,3$ & 3,67 & 1,6092 & $1,3-5,2$ \\
\hline $4 \times 5$ & 0,85 & 0,0888 & $0,3-1,6$ & 1,40 & 0,4933 & $0,7-3,1$ & 1,35 & 0,4220 & $0,8-2,2$ & 3,22 & 1,4459 & $2,0-4,3$ \\
\hline $5 \times 6$ & 0,79 & 0,1104 & $0,1-1,7$ & 1,18 & 0,3074 & $0,3-3,1$ & 1,75 & 0,3961 & $1,1-2,7$ & 2,88 & 0,4658 & $2,0-4,0$ \\
\hline $6 \times 7$ & 0,91 & 0,1171 & $0,3-1,8$ & 1,74 & 0,6078 & $0,5-3,4$ & 2,27 & 0,6311 & $1,1-3,6$ & 2,97 & 1,1546 & $1,3-4,9$ \\
\hline $7 \times 8$ & 0,78 & 0,0903 & $0,3-1,3$ & 1,15 & 0,2268 & $0,5-2,1$ & 1,95 & 1,0368 & $1,2-2,7$ & 2,95 & 0,5941 & $2,4-3,5$ \\
\hline $8 \times 9$ & 0,83 & 0,0785 & $0,3-1,4$ & 1,65 & 0,3214 & $0,8-3,0$ & 1,73 & 0,0018 & $1,7-1,8$ & 1,76 & 0,0098 & $1,7-1,8$ \\
\hline $9 \times 10$ & 0,88 & 0,0961 & $0,8-1,5$ & 1,39 & 0,4002 & $0,5-2,6$ & 0,86 & 0,0041 & $0,8-0,9$ & 1,18 & 0,0113 & $1,1-1,2$ \\
\hline $10 \times 11$ & 0,86 & 0,0782 & $0,3-1,6$ & 1,73 & 0,8158 & $0,4-4,8$ & 1,20 & 0,2909 & $0,4-2,0$ & 2,40 & 1,9344 & $0,8-4,9$ \\
\hline $11 \times 12$ & 1,12 & 0,1463 & $0,3-2,3$ & 1,85 & 0,3574 & $0,8-3,0$ & 1,76 & 0,5222 & $0,7-3,2$ & 3,14 & 1,1083 & $1,2-5,0$ \\
\hline $12 \times 13$ & 1,13 & 0,1986 & $0,2-2,5$ & 2,36 & 0,6006 & $1,0-4,0$ & 1,98 & 0,3045 & $1,3-2,7$ & 3,60 & 0,6467 & $2,2-4,7$ \\
\hline $13 \times 14$ & 1,06 & 0,1080 & $0,4-1,6$ & 2,57 & 1,9840 & $0,6-6,2$ & 1,58 & 0,2744 & $1,1-2,5$ & 4,61 & 0,7349 & $3,5-5,7$ \\
\hline $14 \times 15$ & 0,92 & 0,1426 & $0,3-1,7$ & 2,09 & 0,8052 & $0,4-3,5$ & 1,11 & 0,4555 & $0,5-2,9$ & 2,84 & 2,0462 & $0,7-5,5$ \\
\hline $15 \times 16$ & 1,01 & 0,1930 & $0,5-1,7$ & 1,51 & 0,4992 & $0,8-3,2$ & 2,03 & 0,2178 & $1,7-2,4$ & 3,62 & 0,2178 & $3,3-4,0$ \\
\hline $16 \times 17$ & 0,94 & 0,1642 & $0,3-2,4$ & 1,85 & 0,7593 & $0,3-4,8$ & 1,38 & 0,0041 & $1,3-1,4$ & 4,71 & 0,5941 & $4,2-5,3$ \\
\hline $17 \times 18$ & 0,73 & 0,1070 & $0,2-1,3$ & 1,16 & 0,3025 & $0,4-2,8$ & 1,42 & 0,0145 & $1,3-1,5$ & 2,98 & 1,5138 & $2,1-3,9$ \\
\hline $18 \times 19$ & 0,78 & 0,0801 & $0,2-1,5$ & 1,45 & 0,8000 & $0,2-4,0$ & 1,92 & 0,0426 & $1,8-2,2$ & 2,47 & 0,4157 & $2,0-3,4$ \\
\hline $19 \times 20$ & 0,79 & 0,1188 & $0,3-1,4$ & 1,85 & 1,3666 & $0,2-5,0$ & 1,07 & 0,8606 & $0,2-1,9$ & 3,00 & 3,9394 & $0,6-5,4$ \\
\hline $20 \times 1$ & 0,87 & 0,0835 & $0,3-1,7$ & 1,92 & 0,6381 & $0,3-4,6$ & 1,80 & 0,8797 & $0,3-3,4$ & 3,40 & 0.9192 & $1,4-5,0$ \\
\hline $21 \times 22$ & 0,74 & 0,0963 & $0,2-1,5$ & 1,32 & 0,5115 & $0,2-3,2$ & 1,81 & 1,1617 & $0,4-2,8$ & 2,81 & 0,8962 & $1,7-4,0$ \\
\hline $22 \times 23$ & 0,80 & 0,1151 & $0,4-1,6$ & 1,53 & 400 & $0,4-4,7$ & 1,60 & 0,1058 & $1,4-1,8$ & 2,96 & 0,9941 & $2,3-3,7$ \\
\hline $23 \times 24$ & 0,87 & 0,1142 & $0,3-1,5$ & 1,86 & 1,0157 & $0,4-4,0$ & 1,70 & 0,2118 & $1,2-2,2$ & 4,47 & 1,4075 & $3,3-5,8$ \\
\hline $24 \times 25$ & 1,03 & 0,1581 & $0,1-1,9$ & 2,27 & 0,5151 & $0,5-4,0$ & 1,86 & 0,5414 & $0,6-3,3$ & 3,45 & 0,8875 & $2,0-5,4$ \\
\hline $25 \times 26$ & 1,08 & 0,2752 & $0,5-2,0$ & 2,21 & 0,8831 & $0,8-3,6$ & 1,83 & 0,6258 & $0,9-2,8$ & 4,59 & 0,1750 & $4,1-5,1$ \\
\hline $26 \times 27$ & 0,95 & 0,1121 & $0,2-1,6$ & 1,74 & 0,8051 & $0,2-5,2$ & 1,29 & 0,2811 & $0,3-2,1$ & 2,70 & 0,7929 & $0,6-3,5$ \\
\hline $27 \times 28$ & 0,97 & 0,1371 & $0,5-1,9$ & 2,05 & 0,9643 & $0,6-4,1$ & 2,22 & 0,3019 & $0,7-3,1$ & 3,51 & 1,1741 & $2,0-6,3$ \\
\hline $28 \times 29$ & 0,81 & 0,0877 & $0,3-1,6$ & 1,90 & 0,7076 & $0,4-3,7$ & 1,90 & 0,3384 & $0,8-2,5$ & 2,97 & 0,7114 & $1,6-4,7$ \\
\hline $29 \times 30$ & 0,84 & 0,1515 & $0,3-1,6$ & 1,81 & 0,7482 & $0,1-3,6$ & 1,56 & 0,3274 & $0,8-2,5$ & 2,68 & 0,6777 & $1,4-4,1$ \\
\hline $30 \times 31$ & 0,68 & 0,1737 & $0,1-2,1$ & 1,51 & 0,9737 & $0,2-3,9$ & 1,64 & 0,4277 & $0,6-2,6$ & 3,15 & 0,5308 & $1,8-3,9$ \\
\hline $31 \times 32$ & 0,75 & 0,1298 & $0,2-1,8$ & 2,17 & 1,4559 & $0,4-4,9$ & 1,87 & 0,5008 & $0,5-3,0$ & 4,10 & 0,5836 & $2,8-5,7$ \\
\hline $32 \times 33$ & 1,11 & 0,2009 & $0,3-2,2$ & 2,35 & 1,2454 & $0,6-5,8$ & 1,59 & 0,4509 & $0,5-2,7$ & 4,42 & 0,6809 & $3,0-6,1$ \\
\hline $33 \times 34$ & 1,21 & 0,1931 & $0,4-2,3$ & 2,78 & 1,1824 & $0,5-6,1$ & 1,63 & 0,3776 & $0,6-3,3$ & 4,19 & 0,9118 & $2,2-6,1$ \\
\hline $34 \times 35$ & 1,05 & 0,2218 & $0,3-2,4$ & 2,30 & 0,9546 & $0,2-4,8$ & 2,10 & 0,6411 & $0,8-3,3$ & 4,17 & 0,6194 & $2,3-5,1$ \\
\hline $35 \times 36$ & 0,99 & 0,1770 & $0,2-2,0$ & 2,00 & 1,3702 & $0,1-6,3$ & 1,92 & 0,2078 & $1,4-2,6$ & 5,09 & 0,6800 & $3,7-6,3$ \\
\hline $36 \times 37$ & 1,20 & 0,2239 & $0,2-2,4$ & 2,90 & 1,4854 & $0,7-5,6$ & 1,58 & 0,2257 & $0,8-2,6$ & 3,89 & 0,7376 & $1,1-5,3$ \\
\hline $37 \times 38$ & 1,08 & 0,1713 & $0,4-2,2$ & 2,42 & 1,1431 & $0,4-$ & 1,62 & 0,3825 & $0,9-2,9$ & 4,50 & 0,5841 & $3,6-6,0$ \\
\hline $38 \times 39$ & 0,95 & 0,1210 & $0,2-1,6$ & 1,82 & 0,7888 & & 2,12 & 0,3709 & $1,2-3,1$ & 3,59 & 1,0590 & $2,1-5,3$ \\
\hline $39 \times 40$ & 0,81 & 0,0882 & $0,3-1,5$ & 1,88 & 0,6451 & $-4,0$ & 1,64 & 0,2107 & $1,0-2,1$ & 4,81 & 1,4785 & $3,2-6,1$ \\
\hline $40 \times 21$ & 0,68 & 0,0895 & $0,2-1,5$ & 1,80 & 0,5319 & $0,3-3,4$ & 2.00 & 0,1462 & $1,8-2,6$ & 3.28 & 2.1411 & $2,0-4.8$ \\
\hline Bossier & 0,64 & - & $0,2-14$ & 1,55 & - & $0,4-2,6$ & 1,37 & - & $0,40-2,87$ & 2,05 & - & $44-2,72$ \\
\hline UFV-4 & 0,84 & - & $0,3-14$ & 2,30 & - & $0,5-4,0$ & 1,74 & - & $1,12-2,34$ & 4,97 & - & $, 20-6,27$ \\
\hline IAC-SM & 0,75 & - & $0,2-14$ & 2,51 & - & $1,3-3,5$ & 1,12 & - & $0,34-2,15$ & 4,27 & - & $, 18-6,25$ \\
\hline IAC-12 & 0,96 & - & $0,2-15$ & 1,93 & - & $1,1-4,0$ & 1,95 & - & $0,68-2,61$ & 2.00 & - & $33-2,98$ \\
\hline Progênies & 0,93 & - & & 1,91 & - & - & 1,73 & - & - & 3,59 & - & \\
\hline Testem. & 0,80 & - & & 2,07 & - & - & 1,54 & - & - & 3,32 & - & \\
\hline
\end{tabular}

": Os cruzamentos de $1 \times 2$ até $20 \times 1$ pertencem á cadeia de cruzamentos mista (exótico $\times$ adaptado) e os cruzamentos de $21 \times 22$ até $40 \times 21$ á cadeia de cruzamentos adaptada (adaptado x adaptado). Os números 1,2, .., 40 referem-se aos parentais identificados no Apêndice 3. 
Tabela 16 Porcentagem de óleo (\%OL). Estimativas de médias ajustadas (ฐ), variâncias fenotípicas $\left(\mathrm{S}^{2}\right)$ e intervalo de variação (iv) de cruzamentos em cadeia. Progênies $F_{6: 3}$ (semeaduras em 24 e 25/01/94) e $F_{7: 3}$ (semeaduras em 22 e 28/10/94) de soja avaliadas em dois locais (Areão e Anhembi).

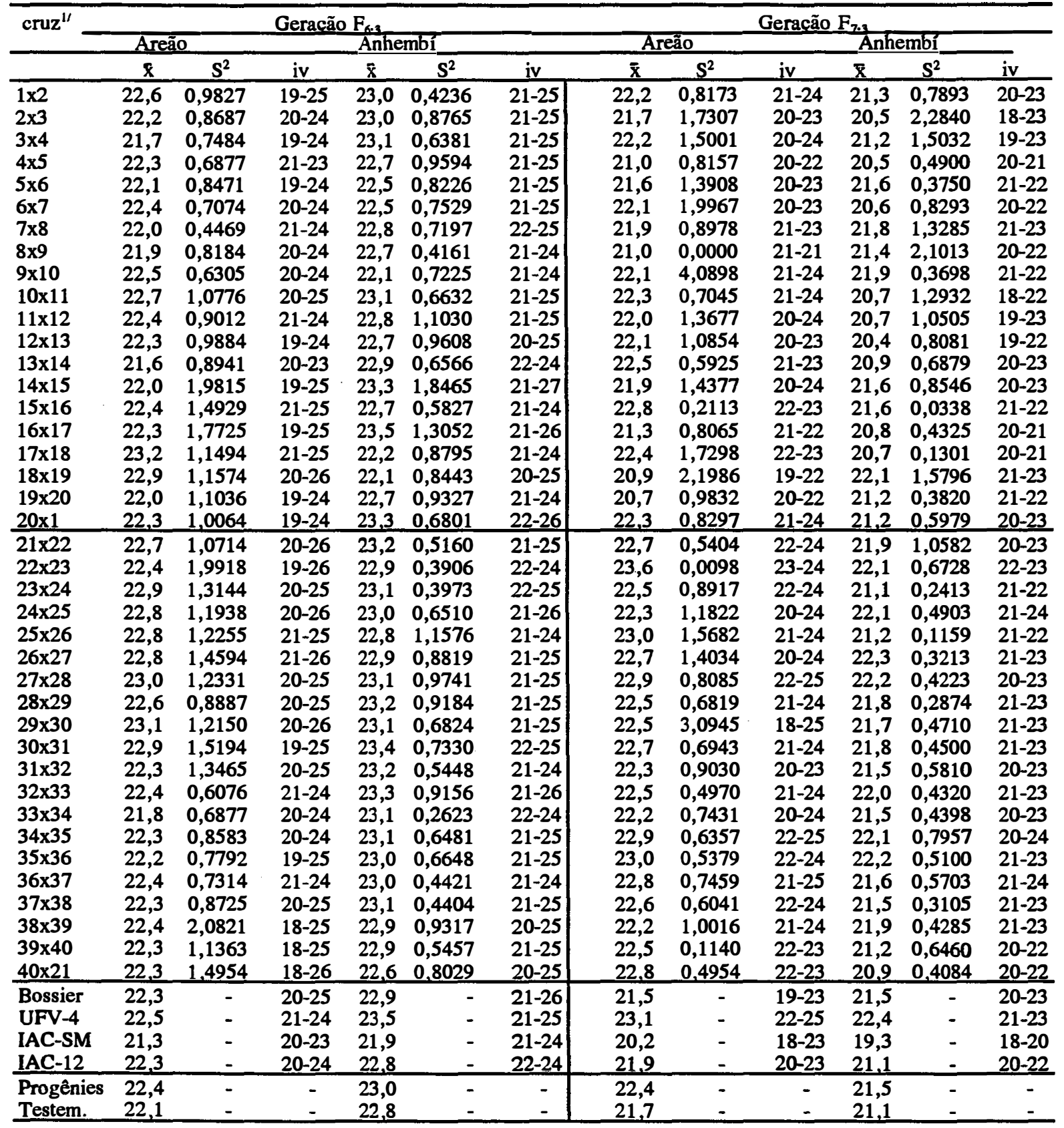

1": Os cruzamentos de $1 \times 2$ até $20 \times 1$ pertencem à cadeia de cruzamentos mista (exótico $\times$ adaptado) e os cruzamentos de $21 \times 22$ até $40 \times 21$ á cadeia de cruzamentos adaptada (adaptado x adaptado). Os números $1,2, \ldots, 40$ referem-se aos parentais identificados no Apêndice 3. 
Tabela 17 Produtividade de óleo (PO). Estimativas de médias ajustadas ( $\overline{\mathrm{x}} \mathrm{em} \mathrm{t} / \mathrm{ha}$ ), variâncias fenotípicas $\left(S^{2}\right)$ e intervalo de variação (iv) de cruzamentos em cadeia. Progênies $\mathrm{F}_{6: 3}$ (semeaduras em 24 e 25/01/94) e $\mathrm{F}_{7: 3}$ (semeaduras em 22 e 28/10/94) de soja avaliadas em dois locais (Areão e Anhembi).

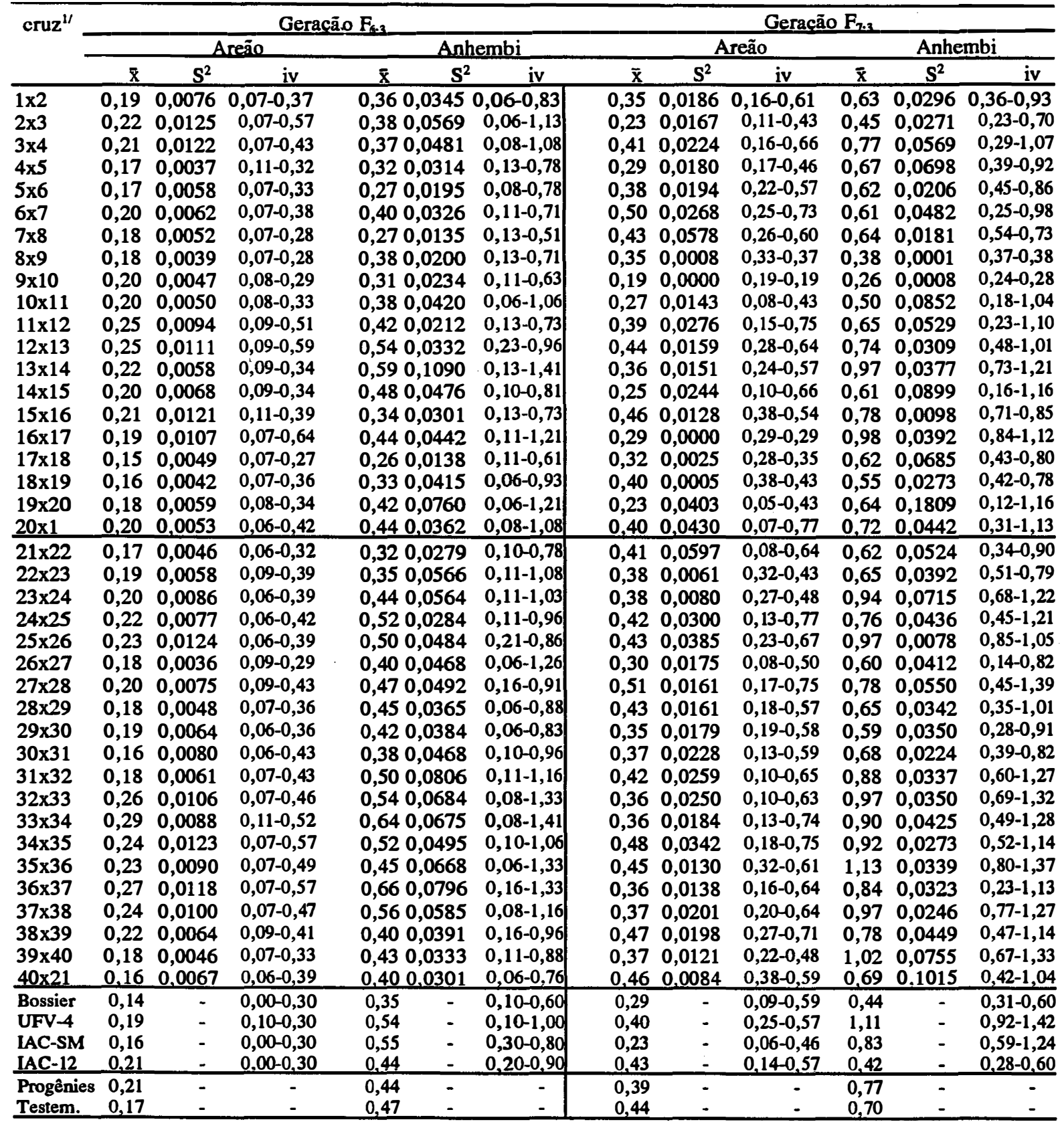

i/: Os cruzamentos de $1 \times 2$ até $20 \times 1$ pertencem á cadeia de cruzamentos mista (exótico x adaptado) e os cruzamentos de $21 \times 22$ até $40 \times 21$ á cadeia de cruzamentos adaptada (adaptado x adaptado).

Os números 1, 2, .., 40 referem-se aos parentais identificados no Apêndice 3. 


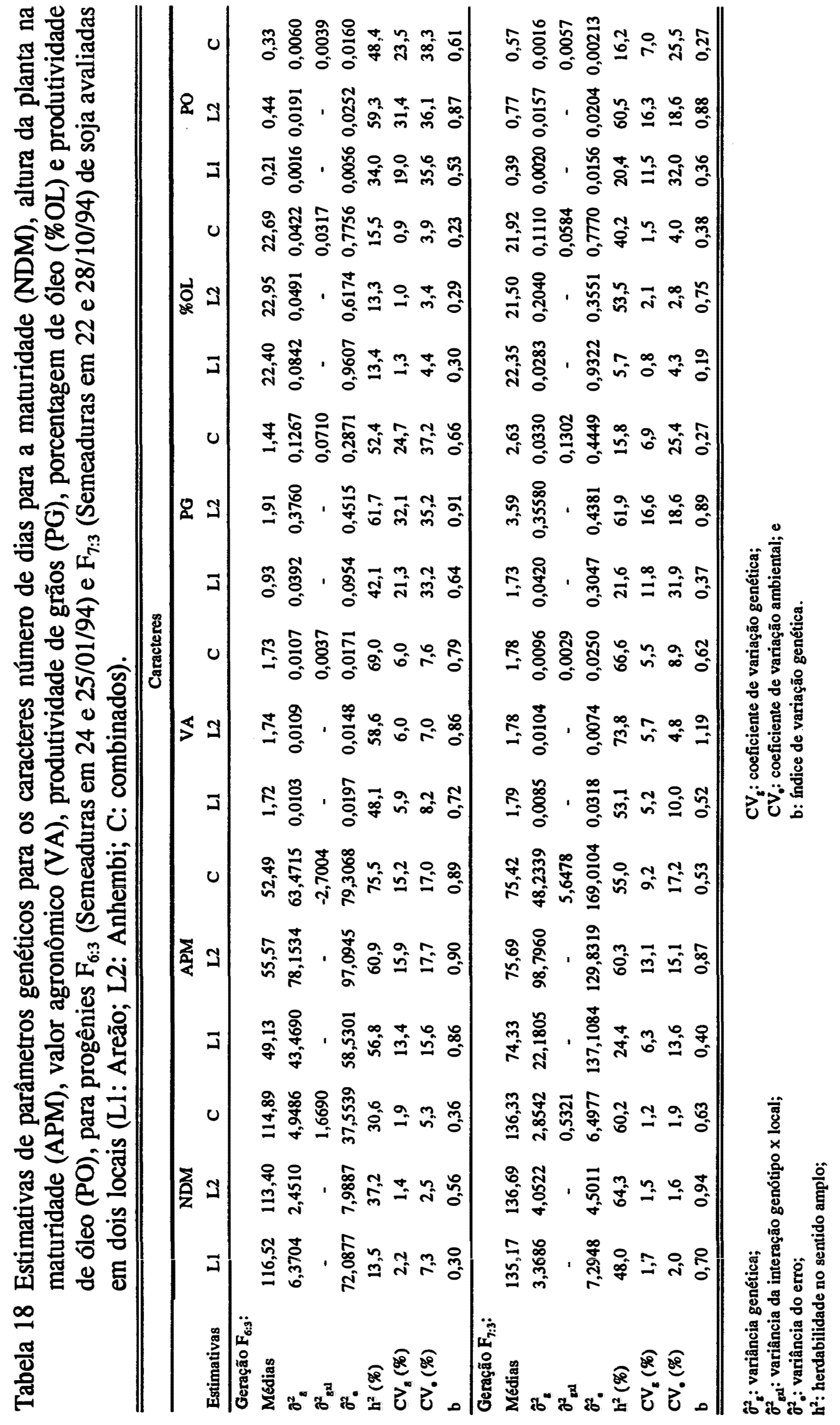




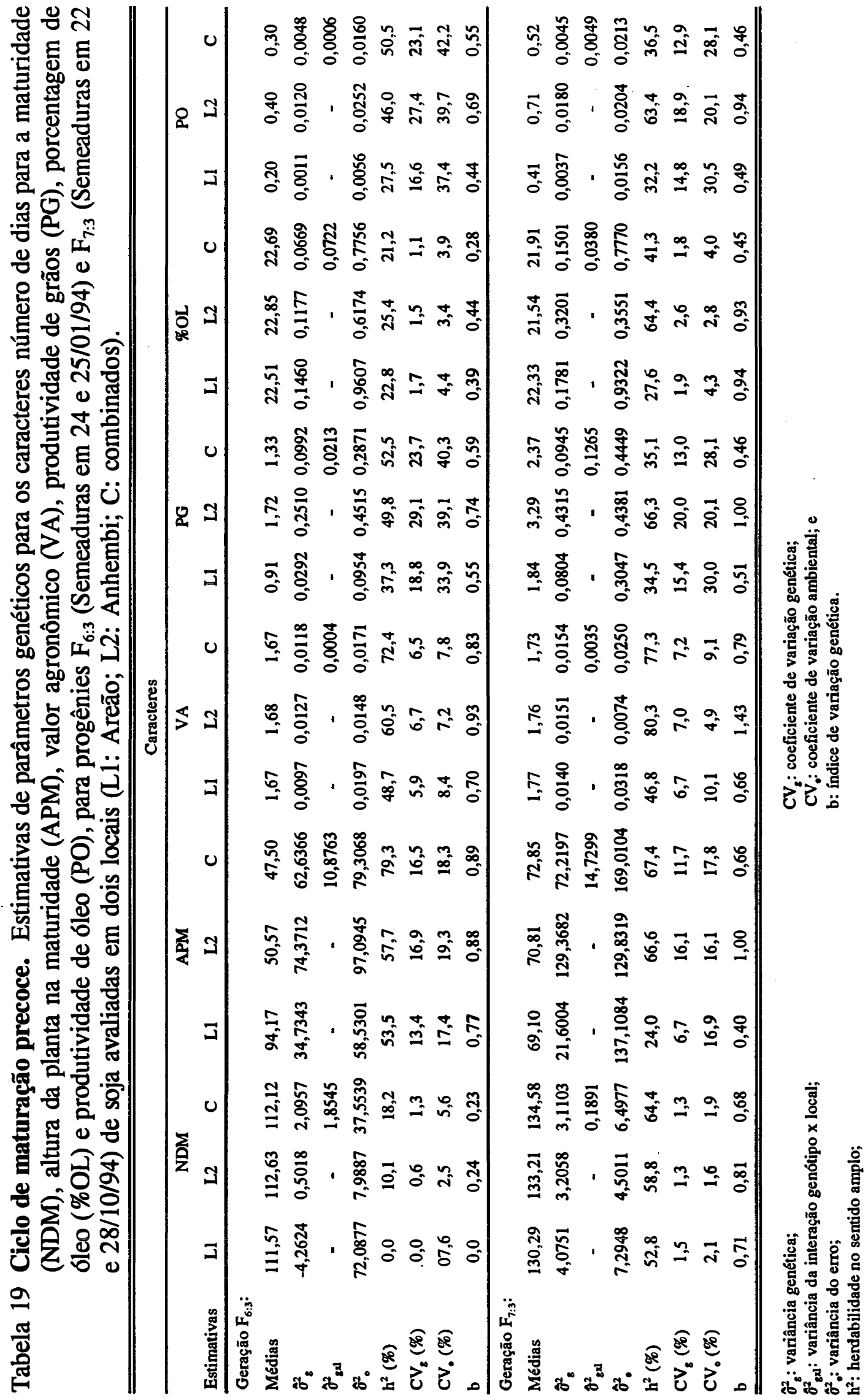




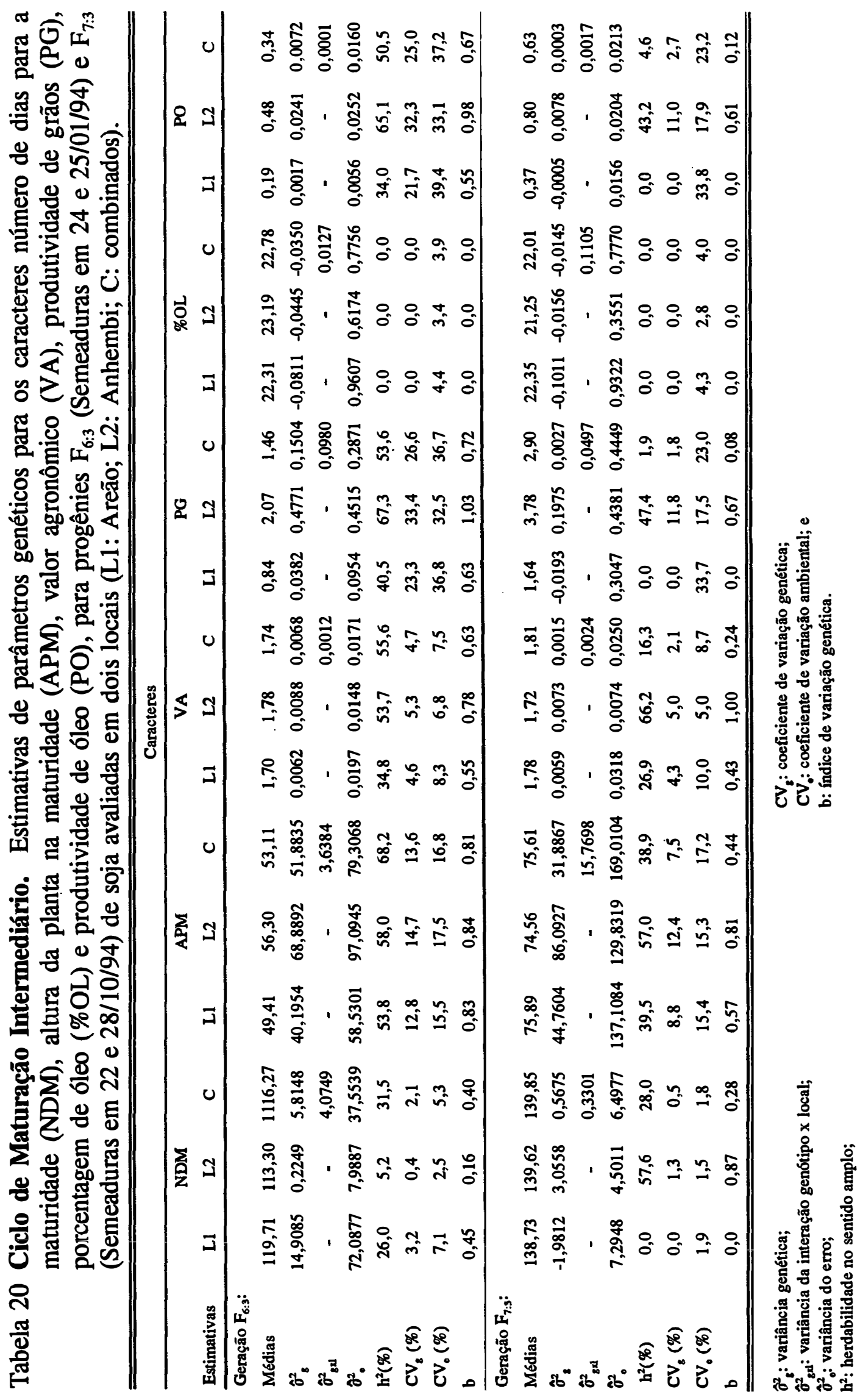




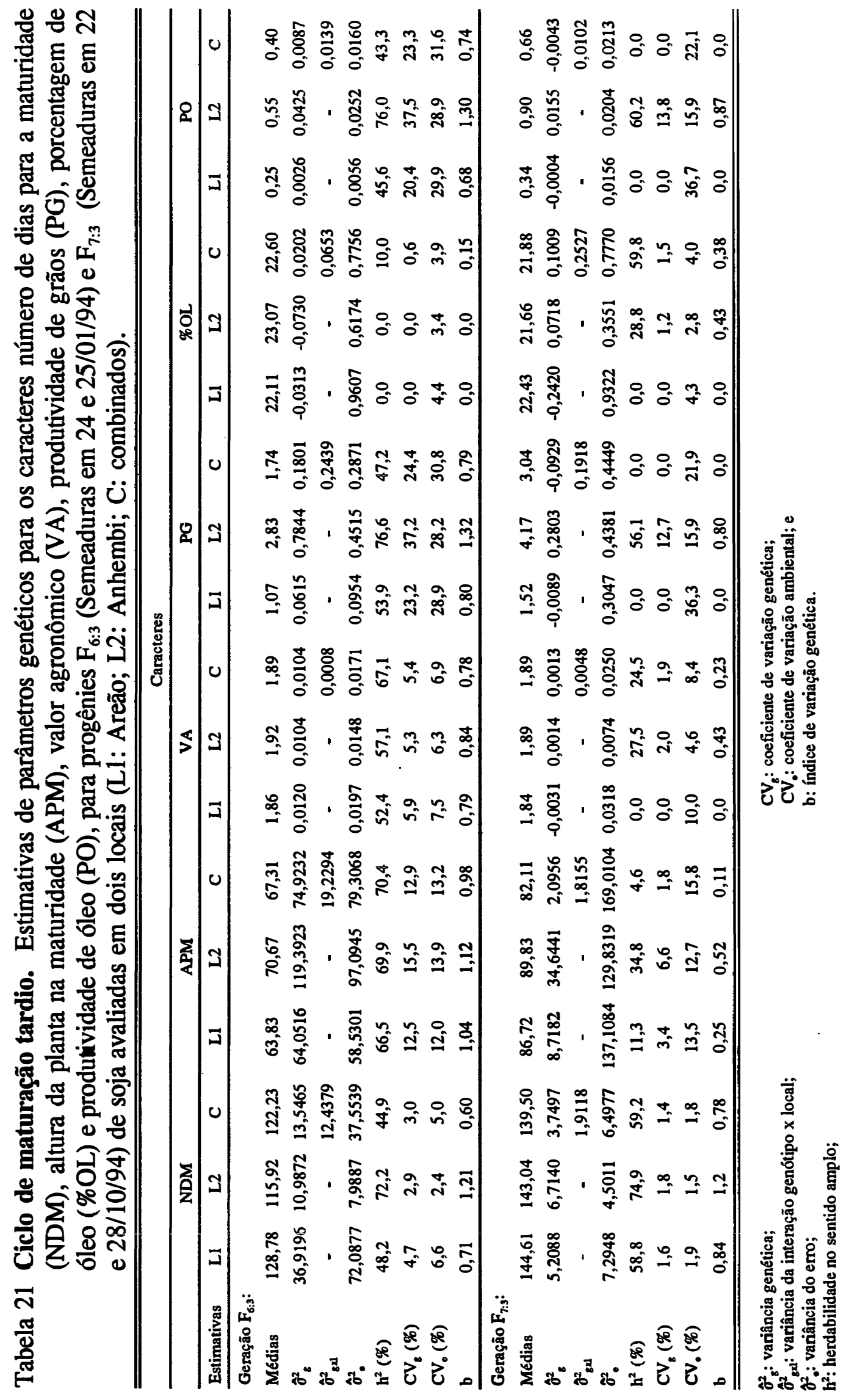


Tabela 22 Estimativas da variância da interação genótipos $x$ locais em progênies $F_{6: 3}$ de soja, proporções dos componentes simples e complexo e a correlação envolvida para o caráter produtividade de grãos. Semeaduras em 24 e 25/01/94, em dois locais (Areão e Anhembi).

\begin{tabular}{|c|c|c|c|c|c|c|}
\hline \multirow[t]{2}{*}{ Progênies } & \multirow[t]{2}{*}{ Médias } & \multirow[t]{2}{*}{ Estimativas } & \multirow[t]{2}{*}{$\%$ do total } & \multicolumn{2}{|c|}{$G \times E$} & \multirow[t]{2}{*}{$\mathbf{r}$} \\
\hline & & & & simples & complexo & \\
\hline & & & \multicolumn{4}{|c|}{............. \% $\%$.............. } \\
\hline Precoces & 1,33 & 0,0213 & 5,9 & 48 & 52 & 0,54 \\
\hline Intermediárias & 1,46 & 0,0980 & 27,0 & 63 & 37 & 0,63 \\
\hline Tardias & 1,74 & 0,2439 & 67,1 & 61 & 39 & 0,56 \\
\hline Geral & 1,44 & 0,0710 & & 55 & 45 & 0,58 \\
\hline
\end{tabular}

Tabela 23 Estimativas da variância da interação genótipos $x$ locais em progênies $F_{7: 3}$ de soja, proporções dos componentes simples e complexo e a correlação envolvida para o caráter produtividade de grãos. Semeaduras em 22 e 28/10/94, em dois locais (Areão e Anhembi).

\begin{tabular}{|c|c|c|c|c|c|c|}
\hline \multirow[t]{2}{*}{ Progênies } & \multirow[t]{2}{*}{ Médias } & \multirow[t]{2}{*}{ Estimativas } & \multirow[t]{2}{*}{$\%$ do total } & \multicolumn{2}{|c|}{$G \times E$} & \multirow[t]{2}{*}{$\mathbf{r}$} \\
\hline & & & & simples & complexo & \\
\hline & & & \multicolumn{4}{|c|}{.............. \% ................ } \\
\hline Precoces & 2,37 & 0,1265 & 34,4 & 20 & 80 & 0,43 \\
\hline Intermediárias & 2,90 & 0,0497 & 13,5 & 17 & 83 & 0,20 \\
\hline Tardias & 3,04 & 0,1918 & 52,1 & 14 & 86 & $-0,23$ \\
\hline Geral & 2,63 & 0,1302 & & 16 & 84 & 0,20 \\
\hline
\end{tabular}


Tabela 24 Ganhos esperados $\left(G_{s}\right)$ e observados $\left(G_{o}\right)$ na seleção entre progênies $F_{6: 3}$ de soja para o caráter produtividade de grãos (PG) com várias modalidades de seleção. Semeaduras em 24 e 25/01/94 em dois locais (Areão e Anhembi).

\begin{tabular}{|c|c|c|c|c|c|c|c|c|c|}
\hline \multirow[t]{2}{*}{$\begin{array}{l}\text { Local de } \\
\text { seleção }\end{array}$} & \multirow[t]{2}{*}{$\begin{array}{l}\text { Local de } \\
\text { resposta }\end{array}$} & \multicolumn{2}{|c|}{$\begin{array}{c}\mathrm{G}_{\mathrm{s}} \text { com base na } \\
\text { média da } \\
\text { população }\end{array}$} & \multicolumn{2}{|c|}{$\begin{array}{c}\mathbf{G}_{\mathbf{s}} \text { com base na } \\
\text { média das } \\
\text { testemunhas }\end{array}$} & \multicolumn{2}{|c|}{$\begin{array}{c}\mathbf{G}_{\text {o com base na }} \\
\text { média da } \\
\text { população } \\
\end{array}$} & \multicolumn{2}{|c|}{$\begin{array}{c}\mathrm{G}_{\mathrm{o}} \text { com base } \\
\text { na média das } \\
\text { testemunhas }\end{array}$} \\
\hline & & t/ha & $\%$ & t/ha & $\%$ & t/ha & $\%$ & t/ha & $\%$ \\
\hline \multicolumn{10}{|c|}{ Geral (23 \% de seleção): } \\
\hline $\mathrm{L}_{1}$ & $\mathrm{~L}_{1}$ & 0,19 & 20,4 & 0,25 & 31,1 & - & - & - & - \\
\hline $\mathrm{L}_{2}$ & $\mathrm{~L}_{2}$ & 0,84 & 44,0 & 0,74 & 35,8 & - & - & - & - \\
\hline $\mathrm{L}_{1}$ & $\mathrm{~L}_{2}$ & 0,53 & 27,8 & 0,43 & 20,9 & - & - & - & - \\
\hline $\mathrm{L}_{2}$ & $\mathrm{~L}_{1}$ & 0,11 & 11,8 & 0,16 & 20,5 & - & - & - & - \\
\hline $\mathbf{C}$ & C & 0,46 & 31,9 & 0,46 & 31,9 & 1,19 & 82,6 & 0,19 & 13,3 \\
\hline $\mathbf{C}$ & $\mathrm{L}_{1}$ & 0,13 & 14,0 & 0,19 & 23,7 & 0,80 & 86,0 & 0,06 & 7,5 \\
\hline C & $\mathrm{L}_{2}$ & 0,82 & 42,9 & 0,72 & 34,9 & 1,68 & 88,0 & 0,43 & 20,8 \\
\hline \multicolumn{10}{|c|}{ Precoces (22 \% de seleção): } \\
\hline $\mathrm{L}_{\mathbf{l}}$ & $\mathrm{L}_{1}$ & 0,16 & 17,6 & 0,20 & 24,7 & - & - & - & - \\
\hline $\mathrm{L}_{2}$ & $\mathrm{~L}_{2}$ & 0,55 & 32,0 & 0,37 & 18,0 & - & - & - & - \\
\hline $\mathrm{L}_{1}$ & $\mathrm{~L}_{2}$ & 0,27 & 15,7 & 0,10 & 4,8 & - & - & - & - \\
\hline $\mathrm{L}_{2}$ & $\mathrm{~L}_{1}$ & 0,08 & 8,8 & 0,12 & 14,9 & - & - & - & - \\
\hline C & C & 0,37 & 27,8 & 0,32 & 22,4 & 1,04 & 78,2 & 0,04 & 2,8 \\
\hline C & $\mathrm{L}_{1}$ & 0,10 & 11,0 & 0,15 & 18,2 & 0,93 & 102,2 & 0,19 & 23,8 \\
\hline $\mathbf{C}$ & $\underline{L_{2}}$ & 0,53 & 30,8 & 0,35 & 17,1 & 1,57 & 91,3 & 0,32 & 15,5 \\
\hline \multicolumn{10}{|c|}{ Intermediárias ( $28 \%$ de seleção): } \\
\hline $\mathrm{L}_{1}$ & $\mathrm{~L}_{1}$ & 0,17 & 20,2 & 0,19 & 23,2 & - & - & - & - \\
\hline $\mathrm{L}_{2}$ & $\mathrm{~L}_{2}$ & 0,75 & 36,2 & 0,75 & 36,2 & - & - & - & - \\
\hline $\mathrm{L}_{1}$ & $\mathrm{~L}_{2}$ & 0,49 & 23,7 & 0,49 & 23,7 & - & - & - & - \\
\hline $\mathrm{L}_{2}$ & $\mathrm{~L}_{1}$ & 0,10 & 11,9 & 0,12 & 14,7 & - & - & - & - \\
\hline C & $\mathrm{C}$ & 0,39 & 26,0 & 0,43 & 30,0 & 1,44 & 98,6 & 0,44 & 30,8 \\
\hline C & $\mathrm{L}_{1}$ & 0,12 & 14,3 & 0,14 & 17,2 & 0,80 & 95,2 & 0,06 & 7,5 \\
\hline C & $\underline{L_{2}}$ & 0,71 & 34,3 & 0,71 & 34,3 & 1,71 & 82,6 & 0,46 & 22,2 \\
\hline \multicolumn{10}{|c|}{ Tardias (25 \% de seleção): } \\
\hline $\mathrm{L}_{1}$ & $\mathrm{~L}_{1}$ & 0,27 & 25,2 & 0,42 & 51,9 & - & - & - & - \\
\hline $\mathrm{L}_{2}$ & $\mathrm{~L}_{2}$ & 1,10 & 46,2 & 1,33 & 64,0 & - & - & - & - \\
\hline $\mathrm{L}_{1}$ & $\mathrm{~L}_{2}$ & 0,67 & 28,2 & 0,90 & 43,7 & - & - & - & - \\
\hline $\mathrm{L}_{2}$ & $\mathrm{~L}_{1}$ & 0,15 & 14,0 & 0,30 & 37,1 & - & - & - & - \\
\hline C & $\mathrm{C}$ & 0,43 & 24,7 & 0,58 & 40,3 & 1,30 & 74,7 & 0,30 & 21,0 \\
\hline C & L1 & 0,18 & 16,8 & 0,33 & 41,1 & 0,45 & 42,1 & $-0,29$ & $-36,3$ \\
\hline C & L2 & 1,09 & 45,8 & $.1,33$ & 64,0 & 1,34 & 47,3 & 0,09 & 4,4 \\
\hline
\end{tabular}

L1: Areão

L2: Anhembi

C: Dois locais combinados 
Tabela 25 Ganhos esperados $\left(G_{s}\right)$ na seleção entre progênies $F_{7: 3}$ de soja para o caráter produtividade de grãos (PG) com varias modalidades de seleção. Semeaduras em 22 e 28/10/94 em dois locais (Areão e Anhembi).

\begin{tabular}{|c|c|c|c|}
\hline \multirow[t]{2}{*}{ Local de seleção } & \multirow[t]{2}{*}{ Local de resposta } & \multicolumn{2}{|c|}{ G com base na média da população } \\
\hline & & t/ha & $\%$ \\
\hline \multicolumn{4}{|c|}{ Geral (35\% de seleção): } \\
\hline L1 & L1 & 0,08 & 4,5 \\
\hline L2 & L2 & 0,71 & 19,8 \\
\hline L1 & L2 & 0,19 & 5,2 \\
\hline L2 & L1 & 0,00 & 0,0 \\
\hline $\mathbf{C}$ & $\mathbf{C}$ & 0,08 & 3,2 \\
\hline $\mathbf{C}$ & $\mathbf{L 1}$ & 0,01 & 0,7 \\
\hline $\mathbf{C}$ & L2 & 0,59 & 16,4 \\
\hline \multicolumn{4}{|c|}{ Precoces (28\% de seleção): } \\
\hline $\mathbf{L} \mathbf{1}$ & L1 & 0,21 & 11,4 \\
\hline L2 & L2 & 0,96 & 29,1 \\
\hline $\mathbf{L 1}$ & L2 & 0,26 & 7,9 \\
\hline L2 & L1 & 0,07 & 3,8 \\
\hline $\mathbf{C}$ & $\mathbf{C}$ & 0,24 & 9,3 \\
\hline $\mathbf{C}$ & L1 & 0,10 & 5,4 \\
\hline $\mathbf{C}$ & $\mathrm{L} 2$ & 0,72 & 21,8 \\
\hline \multicolumn{4}{|c|}{ Intermediárias (47 \% de seleção): } \\
\hline L1 & $\mathbf{L} \mathbf{1}$ & 0,00 & 0,0 \\
\hline L2 & L2 & 0,42 & 11,1 \\
\hline L1 & L2 & 0,05 & 1,3 \\
\hline L2 & L1 & 0,00 & 0,0 \\
\hline $\mathbf{C}$ & $\mathbf{C}$ & 0,01 & 0,4 \\
\hline C & L1 & 0,00 & 0,0 \\
\hline $\mathbf{C}$ & $\mathbf{L} 2$ & 0,35 & 9,3 \\
\hline \multicolumn{4}{|c|}{ Tardias (44 \% de seleção): } \\
\hline L1 & L1 & 0,00 & 0,0 \\
\hline L2 & L2 & 0,37 & 8,9 \\
\hline L1 & L2 & 0,00 & 0,0 \\
\hline L2 & L1 & 0,00 & 0,0 \\
\hline $\mathbf{C}$ & C & 0,00 & 0,0 \\
\hline $\mathbf{C}$ & L1 & 0,00 & 0,0 \\
\hline C & L2 & 0,32 & 7,7 \\
\hline
\end{tabular}

L1: Areão

L2: Anhembi

C : Dois locais combinados 
Tabela 26 Eficiência da seleção indireta e a seleção geral sobre a seleção específica para o caráter produtividade de grãos (PG) em progênies $F_{6: 3}$ de soja. Semeaduras em 24 e 25/01/94, em dois locais (Areão e Anhembi).

\begin{tabular}{lcc}
\hline \multicolumn{1}{c}{ Progênies } & $\begin{array}{c}\text { Seleção indireta sobre a } \\
\text { seleção específica (\%) }\end{array}$ & $\begin{array}{c}\text { Seleção geral baseada na média dos dois locais } \\
\text { sobre a seleção específica (\%) }\end{array}$ \\
\hline Precoces & 49,0 & 89,0 \\
Intermediárias & 64,0 & 90,0 \\
Tardias & 60,0 & 93,0 \\
Geral & 62,0 & 92,0 \\
\hline \hline
\end{tabular}

Tabela 27 Eficiência da seleção indireta e a seleção geral sobre a seleção específica para o caráter produtividade de grãos (PG) em progênies $F_{7: 3}$ de soja. Semeaduras em 22 e 28/10/94, em dois locais (Areão e Anhembi).

\begin{tabular}{lcc}
\hline \multicolumn{1}{c}{ Progênies } & $\begin{array}{c}\text { Seleção indireta sobre a } \\
\text { seleção específica (\%) }\end{array}$ & $\begin{array}{c}\text { Seleção geral baseada na média dos dois } \\
\text { locais sobre a seleção específica (\%) }\end{array}$ \\
\hline Precoces & 33,0 & 72,0 \\
Intermediárias & 43,0 & 87,0 \\
Tardias & 52,0 & 94,0 \\
Geral & 39,0 & 81,0 \\
\hline \hline
\end{tabular}

Tabela 28 Estimativas de médias $(\overline{\mathrm{x}})$ e variâncias genotípicas $\left(\hat{\sigma}_{\mathrm{G}}^{2}\right)$ de cadeias mista e adaptada de cruzamentos biparentais de soja. Progênies $\mathrm{F}_{6: 3}$ (semeaduras em 24 e 25/01/94) e $\mathrm{F}_{7: 3}$ (semeaduras em 22 e 28/10/94) em dois locais (Areão e Anhembi).

\begin{tabular}{|c|c|c|c|c|c|c|c|c|c|}
\hline \multirow[t]{3}{*}{ Caracteres } & \multirow[t]{3}{*}{ Unidades } & \multicolumn{4}{|c|}{ Cadeia mista (Exótico x Adaptado) } & \multicolumn{4}{|c|}{ Cadeia adaptada (Adaptado x Adaptado) } \\
\hline & & \multicolumn{2}{|c|}{$F_{6: 3}$} & \multicolumn{2}{|c|}{$F_{7: 3}$} & \multicolumn{2}{|c|}{$F_{6: 3}$} & \multicolumn{2}{|c|}{$\mathbf{F}_{7: 3}$} \\
\hline & & $\bar{x}$ & $\hat{\sigma}_{0}^{2}$ & $\overline{\mathbf{x}}$ & $\partial_{a}^{2}$ & $\overline{\mathbf{x}}$ & $\hat{\sigma}_{0}^{2}$ & $\bar{x}$ & $\hat{\sigma}_{0}^{2}$ \\
\hline NDM & dias & 114,09 & 10,7770 & 135,66 & 2,3235 & 115,51 & 13,8778 & 136,73 & 4,3651 \\
\hline APM & cms & 48,24 & 90,7271 & 68,76 & 46,7884 & 55,75 & 90,1406 & 79,36 & 43,9463 \\
\hline VA & notas & 2,32 & 0,0141 & 2,39 & 0,0108 & 2,63 & 0,0123 & 2,85 & 0,0099 \\
\hline PG & t/ha & 1,31 & 0,1174 & 2,40 & 0,1489 & 1,54 & 0,1390 & 2,77 & 0,0196 \\
\hline$\% \mathrm{OL}$ & $\%$ & 22,58 & 0,0244 & 21,75 & 0,2534 & 22,77 & 0,0480 & 22,03 & 0,0209 \\
\hline PO & $\mathrm{t} / \mathrm{ha}$ & 0,30 & 0,0062 & 0,52 & 0,0070 & 0,35 & 0,0063 & 0,61 & 0,0012 \\
\hline
\end{tabular}


Tabela 29 Estimativas de correlações genotípicas, fenotípicas e ambientais em progênies $\mathrm{F}_{6: 3}$ (semeaduras em 24 e 25/01/94) e $\mathrm{F}_{7: 3}$ (semeaduras em 22 e 28/10/94) de soja em dois locais individuais e combinados.

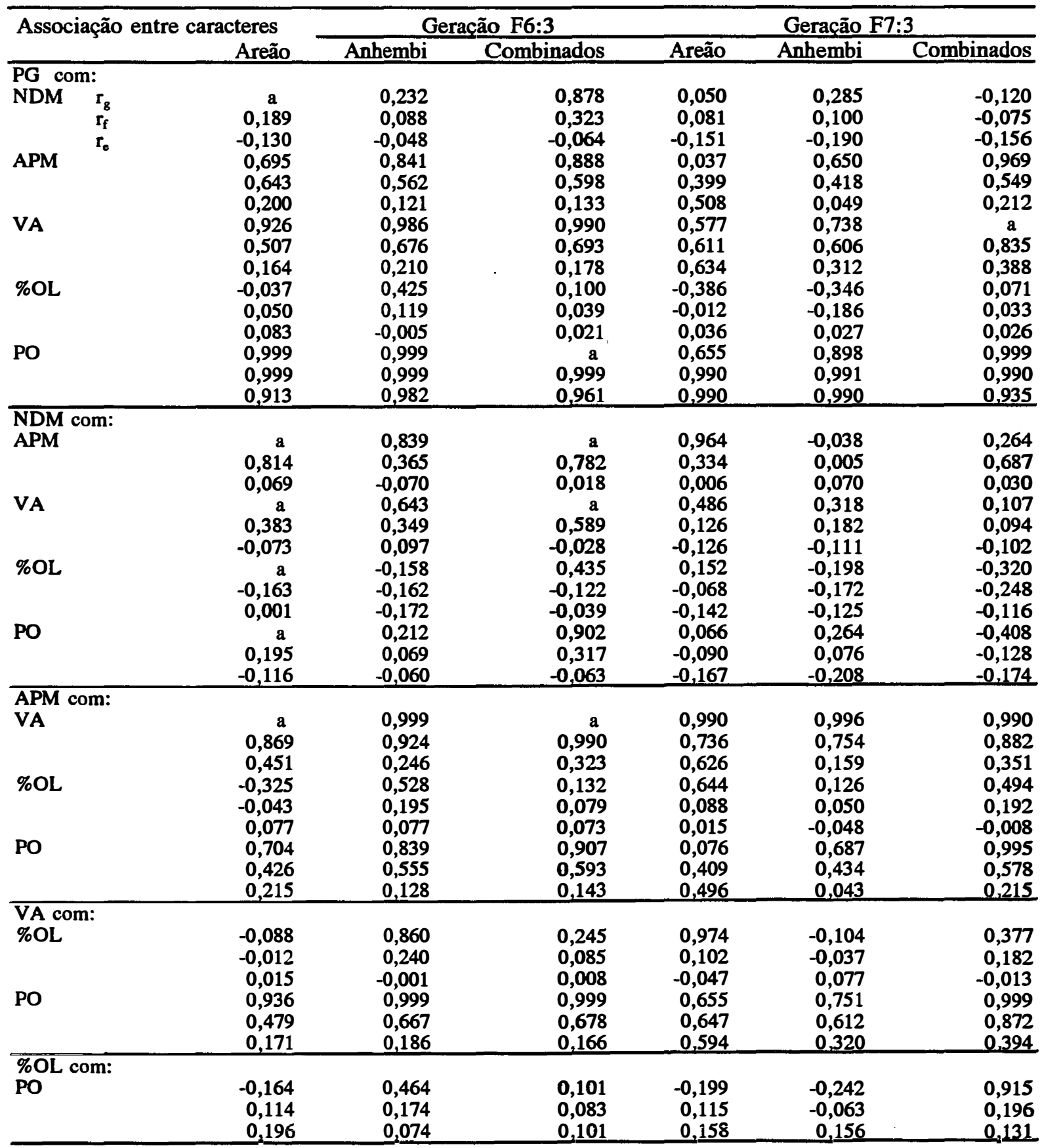

$\mathbf{r}_{\mathbf{g}}$ : Correlação genotípica $\quad \mathbf{r}_{\mathbf{f}}$ : Correlação fenotípica

$\mathbf{r}_{\mathrm{e}}$ : Correlação ambiental

a: estimativas maiores que a unidade (1). 
Tabela 30 Análise conjunta de variância para os caracteres número de dias para a maturidade (NDM), altura da planta na maturidade (APM), valor agronômico (VA), produtividade de grãos (PG), porcentagem de óleo (\%OL) e produtividade de óleo (PO) de soja avaliada em dois locais (Areão e Anhembi) e duas épocas de semeadura ( 24 e 25/01/94 para progênies $F_{6: 3}$ e 22 e 28/10/94 para progênies $F_{7: 3}$ ).

\begin{tabular}{|c|c|c|c|c|c|c|c|}
\hline Fontes de variação & $\mathbf{G L}$ & NDM & $\overline{\mathrm{APM}}$ & VA $^{1 /}$ & PG & $\% \mathrm{OL}$ & PO \\
\hline Locais (L) & 1 & $369,1478^{\text {NS }}$ & $8625,3884 *$ & $0,5577^{\mathrm{NS}}$ & $637,2826 * *$ & $19,2579^{\mathrm{NS}}$ & $30,3672 * *$ \\
\hline Epocas (A) & 1 & $134179,9288 * *$ & $72224,3447 * *$ & $2,4392^{\text {NS }}$ & $22,0567 *$ & $386,7134 * *$ & $0,3790 *$ \\
\hline LXA & 1 & $2313,9067^{*}$ & $3596,0721^{\mathrm{NS}}$ & $0,0041^{\mathrm{NS}}$ & $5,3738^{\mathrm{NS}}$ & $225,0894 *$ & $0,9356^{\mathrm{NS}}$ \\
\hline Repetições/L/A & 4 & $360,9716 * *$ & $885,9815 * *$ & $1,6127 * *$ & $28,3699 * *$ & $12,7650 * *$ & $1,2881 * *$ \\
\hline Cruzamentos (Cr) & 39 & $498,3278 * *$ & $3582,5586^{* *}$ & $0,3842^{* *}$ & $4,1567^{\mathrm{NS}}$ & $2,8227^{\mathrm{NS}}$ & $0, \overline{2} 162^{\mathrm{NS}}$ \\
\hline Progênies (P)/Cr & 169 & $88,4751 * *$ & $468,8247 * *$ & $0,0633 * *$ & $0,8730 * *$ & $1,4178 * *$ & $0,0438^{N S}$ \\
\hline -Precoces (M) & 83 & $55,6825 * *$ & $561,9315 * *$ & $0,0838 * *$ & $0,9415 *$ & $1,8890 * *$ & $0,0443 *$ \\
\hline -Intermediárias (I) & 23 & $16,1941^{\text {NS }}$ & $246,8412^{\mathrm{NS}}$ & $0,0325^{\mathrm{NS}}$ & $0,4938^{\mathrm{NS}}$ & $0,6898^{\mathrm{NS}}$ & $0,0285^{\mathrm{NS}}$ \\
\hline -Tardias $(T)$ & 35 & $38,3875^{\mathrm{NS}}$ & $244,3045^{\mathrm{NS}}$ & $0,0252^{\mathrm{NS}}$ & $0,4404^{\mathrm{NS}}$ & $0,6050^{\mathrm{NS}}$ & $0,0238^{N S}$ \\
\hline $\mathrm{L} \times \mathrm{C}_{\mathbf{r}}$ & $\overline{3} \overline{9}$ & $130,6146^{\mathrm{N}}$ & $200,1159 * *$ & $0, \overline{0} 266^{\mathrm{N} S}$ & $2, \overline{9224 * *}$ & $1,6584^{\mathrm{NS}}$ & $\overline{0}, \overline{14} 22^{* *}$ \\
\hline $\mathrm{AxCr}$ & 39 & $56,7328^{\mathrm{NS}}$ & $326,4723^{\mathrm{NS}}$ & $0,0538^{\mathrm{NS}}$ & $1,4208^{\mathrm{NS}}$ & $1,7383^{\mathrm{NS}}$ & $0,0747^{\mathrm{NS}}$ \\
\hline $\mathrm{LxAxCr}$ & 39 & $100,5046 * *$ & $189,8647 * *$ & $0,0268 *$ & $0,9182 *$ & $1,5775 * *$ & $0,0454^{\mathrm{NS}}$ \\
\hline$\overline{\mathrm{LXP} / \mathbf{C}_{\mathbf{r}}}$ & 169 & $23,5089^{N \mathrm{NS}}$ & $133,0874^{\mathrm{NS}^{-}}$ & $\overline{0,0132^{\mathrm{N} S}}$ & $0,6042^{\mathrm{NS}}$ & $0,7408^{\mathrm{NS}}$ & $0, \overline{0} 86^{\mathrm{NS}}$ \\
\hline$-\mathrm{LxM}$ & 83 & $20,2878^{N S}$ & $94,8446^{\mathrm{NS}}$ & $0,0112^{\mathrm{NS}}$ & $0,5315^{\mathrm{NS}}$ & $0,7804^{\mathrm{NS}}$ & $0,0246^{\mathrm{NS}}$ \\
\hline -LxI & 23 & $9,4918^{\mathrm{NS}}$ & $138,7124^{\mathrm{NS}}$ & $0,0164^{\mathrm{NS}}$ & $0,3793^{\mathrm{NS}}$ & $0,6980^{\mathrm{NS}}$ & $0,0195^{\mathrm{NS}}$ \\
\hline$-\mathrm{LxT}$ & 35 & $17,9165^{\mathrm{NS}}$ & 169,0500 & $0,0120^{\mathrm{NS}}$ & $0,6071^{\mathrm{NS}}$ & $0,4110^{\mathrm{NS}}$ & $0,0294^{\mathrm{NS}}$ \\
\hline $\mathrm{AxP} / \mathrm{Cr}$ & 169 & $23,4000^{\mathrm{NS}}$ & $152,5993 *$ & $\overline{0,0317^{* *}}$ & $0,6385^{\mathrm{NS}}$ & $\overline{0,8130 *}$ & $\overline{0}, \overline{0} 321^{\mathrm{NS}}$ \\
\hline$-\mathbf{A x M}$ & 83 & $18,0098^{\mathrm{NS}}$ & $116,0659^{\mathrm{NS}}$ & $0,0294 * *$ & $0,4759^{\mathrm{NS}}$ & $0,8223^{\mathrm{NS}}$ & $0,0234^{\mathrm{NS}}$ \\
\hline$-A x I$ & 23 & $10,7488^{\mathrm{NS}}$ & $226,8786^{\mathrm{NS}}$ & $0,0185^{\mathrm{NS}}$ & $0,4238^{\mathrm{NS}}$ & $0,7411^{\mathrm{NS}}$ & $0,0215^{\mathrm{NS}}$ \\
\hline$-A x T$ & 25 & $19,9197^{\mathrm{NS}}$ & $112,7753^{\mathrm{NS}}$ & $0,0226^{\mathrm{NS}}$ & $0,4537^{\mathrm{NS}}$ & $0,4664^{\mathrm{NS}}$ & $0,0255^{\mathrm{NS}}$ \\
\hline $\mathrm{LxAxP} / \mathrm{Cr}$ & 169 & $23,2669^{\mathrm{NS}}$ & $115,7766^{* *}$ & $0,0177^{\mathrm{N} s}$ & $0,5713^{* *}$ & $0,6301^{\mathrm{NS}}$ & $0,0288^{* *}$ \\
\hline$-\mathrm{LxAxM}$ & 83 & $18,9688^{\mathrm{NS}}$ & $100,3857^{\mathrm{NS}}$ & $0,0149^{\mathrm{NS}}$ & $0,4976 *$ & $0,6304^{\mathrm{NS}}$ & $0,0242 *$ \\
\hline$-\mathrm{LxAxI}$ & 23 & $12,1671^{\mathrm{NS}}$ & $186,6507 * *$ & $0,0255^{\mathrm{NS}}$ & $0,5923 *$ & $0,4716^{\mathrm{NS}}$ & $0,0298 *$ \\
\hline -LxAxT & 35 & 14,2832 & $79,3609^{\mathrm{NS}}$ & $0,0154^{\mathrm{NS}}$ & $0,5808 *$ & $0,3907^{\mathrm{NS}}$ & $0,0335 *$ \\
\hline Erro & 832 & 14,5496 & 108,6298 & 0,0167 & 0,3954 & 0,6317 & 0,0202 \\
\hline Erro Méd.Conj.Geral & 2250 & 31,6729 & 89,3692 & 0,0175 & 0,3028 & 0,7511 & 0,0164 \\
\hline Média das progênies & & 125,97 & $-67,04$ & 1,81 & 2,35 & 22,35 & 0,52 \\
\hline & C.V.\% & 3,7 & 15,4 & 7,5 & 24,4 & 3,8 & 25,1 \\
\hline & $\mathbf{R}^{2}$ & 0,95 & 0,84 & 0,76 & 0,87 & 0,74 & 0,86 \\
\hline
\end{tabular}

$*$, **: significativo a $5 \%$ e $1 \%$, respectivamente.

Ns: não significativo.

1/: transformado por $\sqrt{x+0,5}, \quad x=1$ a 5 . 
Tabela 31 Estimativas de componentes de variância e herdabilidade para seis caracteres em soja cultivada em dois locais (Areão e Anhembi) e duas épocas de semeadura ( 24 e $25 / 01 / 94$ para $F_{6: 3}$ e 22 e 28/10/94 para $F_{7: 3}$ ).

\begin{tabular}{|c|c|c|c|c|c|c|c|c|}
\hline \multirow[t]{2}{*}{ Caracteres } & \multirow[t]{2}{*}{ Ciclo das progênies } & \multirow[t]{2}{*}{ Média } & \multicolumn{6}{|c|}{ Estimativas } \\
\hline & & & $\hat{\sigma}_{\mathbf{G}}^{2}$ & $\hat{\sigma}_{\mathrm{GxL}}^{2}$ & $\hat{\sigma}_{\mathrm{G} \times \mathrm{A}}$ & $\hat{\sigma}_{G \times L x A}^{2}$ & $\hat{\sigma}_{E}^{2}$ & $\overline{\mathrm{h}}^{2}$ \\
\hline NDM & Geral & 126 & 8,1208 & $-2,0410$ & 0,0166 & $-2,1015$ & 31,6729 & 67,2 \\
\hline \multirow[t]{3}{*}{ (dias) } & Precoces & 122 & 4,4243 & $-2,8463$ & $-0,1199$ & $-3,1761$ & 31,6729 & 52,8 \\
\hline & Intermediárias & 128 & 0,8378 & $-5,5453$ & $-0,1773$ & $-4,8764$ & 31,6729 & 17,5 \\
\hline & Tardias & 134 & 2,5589 & $-3,4391$ & 0,7046 & $-4,3470$ & 31,6729 & 37,2 \\
\hline APM & Geral & 67 & 41,9672 & 10,9296 & 4,6029 & 6,6019 & 89,3692 & 67,1 \\
\hline \multirow[t]{3}{*}{ (cm) } & Precoces & 62 & 58,3859 & 1,3689 & 1,9601 & 2,7542 & 89,3692 & 81,2 \\
\hline & Intermediárias & 67 & 13,5161 & 12,3358 & 5,0285 & 24,3204 & 89,3692 & 34,3 \\
\hline & Tardias & 80 & 9,4068 & 19,9202 & 4,1768 & $-2,5021$ & 89,3692 & 28,8 \\
\hline VA & Geral & 2,8 & 0,0063 & $-0,0011$ & 0,0018 & 0,0001 & 0,0175 & 66,9 \\
\hline (notas & Precoces & 2,7 & 0,0091 & $-0,0016$ & 0,0018 & $-0,0007$ & 0,0175 & 74,7 \\
\hline \multirow[t]{2}{*}{1 a 5$)$} & Intermediárias & 2,7 & 0,0020 & $-0,0003$ & $-0,0009$ & 0,0020 & 0,0175 & 42,7 \\
\hline & Tardias & 3,1 & 0,0017 & $-0,0014$ & 0,0018 & $-0,0003$ & 0,0175 & 35,5 \\
\hline PG & Geral & 2,35 & 0,0336 & 0,0754 & 0,0084 & 0,0672 & 0,3028 & 25,8 \\
\hline \multirow[t]{3}{*}{$(\mathrm{t} / \mathrm{ha})$} & Precoces & 2,26 & 0,0513 & 0,0572 & $-0,0027$ & 0,0487 & 0,3028 & 39,5 \\
\hline & Intermediárias & 2,38 & 0,0143 & 0,0191 & $-0,0211$ & 0,0724 & 0,3028 & 17,9 \\
\hline & Tardias & 2,57 & $-0,0208$ & 0,0761 & $-0,0159$ & 0,0695 & 0,3028 & 0,0 \\
\hline \multirow[t]{4}{*}{$\% \mathrm{OL}$} & Geral & 22,4 & 0,0846 & $-0,0026$ & 0,0229 & $-0,0303$ & 0,7511 & 44,6 \\
\hline & Precoces & 22,4 & 0,1386 & 0,0073 & 0,0240 & $-0,0302$ & 0,7511 & 55,9 \\
\hline & Intermediárias & 22,3 & $-0,0010$ & $-0,0133$ & 0,0337 & $-0,0699$ & 0,7511 & 0,0 \\
\hline & Tardias & 22,3 & 0,0242 & $-0,0850$ & 0,0095 & $-0,0901$ & 0,7511 & 19,7 \\
\hline PO & Geral & 0,52 & 0,0019 & 0,0031 & 0,0004 & 0,0031 & 0,0164 & 29,3 \\
\hline \multirow[t]{3}{*}{$(\mathrm{t} / \mathrm{ha})$} & Precoces & 0,50 & 0,0025 & 0,0021 & $-0,0001$ & 0,0020 & 0,0164 & 41,0 \\
\hline & Intermediárias & 0,53 & 0,0011 & 0,0008 & $-0,0011$ & 0,0034 & 0,0164 & 25,0 \\
\hline & Tardias & 0,57 & $-0,0007$ & 0,0033 & $-0,0010$ & 0,0043 & 0,0164 & 0,0 \\
\hline
\end{tabular}

$\hat{\sigma}_{\mathbf{G}}:$ Variância genotípica;

$\hat{\sigma}_{\text {GxL }}^{2}$ : Variância da interação genótipos $x$ locais;

$\hat{\sigma}^{2} \mathbf{O x A}:$ Variância da interação genótipos $\mathrm{x}$ épocas;

$\hat{\sigma}_{G x l a A}$ : Variância da interação genótipos $\mathrm{x}$ locais $\mathrm{x}$ épocas;

$\hat{\sigma}_{\mathrm{E}}^{2}$ : Variância do erro médio conjunto geral;

$\bar{h}^{2}$ : herdabilidade no sentido amplo (Para o cálculo da herdabilidade as variâncias com sinal negativo foram consideradas como sendo zero). 
138

APÊNDICES 
Apêndice 1 Estimativas de herdabilidade para vários caracteres na cultura da soja.

\begin{tabular}{|c|c|c|c|c|c|c|c|c|c|c|c|c|}
\hline \multirow[t]{2}{*}{ Local } & \multirow[t]{2}{*}{ Método } & \multicolumn{10}{|c|}{ Caracteres } & \multirow[t]{2}{*}{ Fonte } \\
\hline & & NDF & APF & NDM & APM & $\mathrm{AC}$ & VA & PG & $\mathrm{OL}$ & $\mathrm{PO}$ & PROT & \\
\hline \multirow[t]{4}{*}{ EUA } & F2 & & & & 41 & & & 43 & & & & \multirow[t]{4}{*}{$1 /$} \\
\hline & Reg F2-F3 & & & 50 & 35 & & & 6 & & & & \\
\hline & Reg F4-F3 & & & 100 & 91 & & & 77 & & & & \\
\hline & Anova F4 & & & 92 & 74 & & & 67 & & & & \\
\hline EUA & P1 P2 F1 F2 & $66-83$ & & $67-86$ & $50-76$ & & & $78-60$ & 49-59 & & & 21 \\
\hline EUA & Anova F4 e F5 & $84-89$ & & 71 & $61-81$ & $34-73$ & & $25-40$ & $68-78$ & & $39-83$ & $3 /$ \\
\hline EUA & Linhagens & & & & & & & & $63-74$ & & & $4 /$ \\
\hline \multirow{2}{*}{ EUA } & Anova F3 & $65-91$ & & $81-86$ & 73.84 & $43-61$ & & $23-50$ & & & & \multirow[t]{2}{*}{51} \\
\hline & Reg F4-F3 & $49-91$ & & $74-84$ & $58-74$ & $35-54$ & & $15-27$ & & & & \\
\hline EUA & Anova F4 e F5 & $75-76$ & & $79-82$ & $67-70$ & $51-74$ & & $3-10$ & 51 & & 57 & $6 /$ \\
\hline EUA & Linhagens & & & $61-94$ & $68-88$ & $49-81$ & & $10-75$ & $75-93$ & & $71-92$ & 71 \\
\hline EUA & F4 & & & & & & & $0-73$ & & & $81-96$ & 81 \\
\hline INDIA & Cultivares & 99 & & 99 & 94 & & & 44 & & & & 9/ \\
\hline EUA & & & & & & & & & $75-84$ & & & $10 /$ \\
\hline EUA & $\begin{array}{l}\text { Sel. massal } \\
\text { Meias irmās }\end{array}$ & & & & & & & & $\begin{array}{l}28 \\
20\end{array}$ & & & $11 /$ \\
\hline EUA & Anova F3 e F4 & & & $62-83$ & $51-61$ & & & $11-54$ & $49-66$ & & $28-56$ & 121 \\
\hline EUA & Anova F3 e F4 & & & & & & & & $71-93$ & & $75-90$ & $13 /$ \\
\hline PORTO & F4 & & & & & & & & & & & \multirow[t]{4}{*}{$14 /$} \\
\hline \multirow[t]{3}{*}{ RICO } & Planta individual & & & & & & & & $34-41$ & & $40-62$ & \\
\hline & Media de parcela & & & & & & & & $39-44$ & & $46-67$ & \\
\hline & Media de progên & & & & & & & & $89-92$ & & $91-98$ & \\
\hline CANADA & F2 & & & & & & & & $58-68$ & & $76-83$ & $15 /$ \\
\hline INDIA & P1 P2 F1 F2 & & & & $12-29$ & & & $37-60$ & $89-91$ & & $83-91$ & $16 /$ \\
\hline BRASIL & $\begin{array}{l}\text { F2 (verảo) } \\
\text { F3 (inverno) }\end{array}$ & $\begin{array}{l}82 \\
28-68\end{array}$ & $\begin{array}{l}68 \\
0-57\end{array}$ & $\begin{array}{l}91 \\
33-77\end{array}$ & $\begin{array}{l}59 \\
0-44\end{array}$ & & & & & & & 171 \\
\hline CUBA & Cultivares & & & & $78-80$ & & & $6-52$ & & & & $18 /$ \\
\hline BRASIL & S1 (sel. rec.) & & & & & & & & $66-85$ & & & $19 / *$ \\
\hline EUA & S1 (sel. rec) & & & & & & & & $43-62$ & & & $20 /$ \\
\hline BRASIL & P1 P2 F1 F2 & 29-99 & $21-83$ & $22-99$ & $38-91$ & & $42-86$ & 21-92 & $37-79$ & $27-92$ & & $21 /$ \\
\hline INDIA & Linhagens & & & & & & & & 51 & & 44 & 221 \\
\hline EUA & Progênies F5 & 92 & & 98 & 93 & 76 & & 86 & 88 & & 83 & $23 /$ \\
\hline EUA & Progênies F7 & & & & & & & $7-42$ & $70-77$ & & $68-82$ & $24 /$ \\
\hline NIGERIA & Linhagens & & & & & & & $23-45$ & & & & $25 /$ \\
\hline BRASIL & F3 & $15-98$ & $10-97$ & $16-95$ & 32-97 & & $10-95$ & $6-87$ & $13-79$ & $9-91$ & & $26 /$ \\
\hline \multirow[t]{3}{*}{ BRASIL } & Anova F4 & & & 93-98 & $0-71$ & $0-88$ & $50-81$ & $0-60$ & $0-74$ & $0-77$ & & \multirow[t]{3}{*}{271} \\
\hline & Reg F4-F3 & & & $28-96$ & 24-94 & 52 & 59 & & $21-95$ & & & \\
\hline & Reg F5-F4 & & & $21-85$ & $40-74$ & 45 & 52 & 24-78 & $43-81$ & $24-74$ & & \\
\hline BRASIL & Progênies F6 & 94 & 92 & 89 & 98 & & & 58 & & & & $28 /$ \\
\hline
\end{tabular}

$1 /$ Mahmud \& Kramer, 1951

2/ Weber \& Moorthy, 1952

3/ Johnson et al., 1955

4/ Hanson \& Weber, 1962

5/ Anand \& Torrie, 1963

6/ Kwon \& Torrie, 1964

7/ Smith \& Weber, 1968

8/ Shannon et al, 1972

9/ Lal \& Haque, 1972
10/ Shorter et al., 1977

11/ Burton \& Brim, 1981

12/ Monteverde, 1984

13/ Openshaw \& Hadley, 1984

14/ Rodriguez de Cianzio et al., 1985

15/ McKendry et al., 1985

16/ Malik \& Singh, 1987

17/ Machado dos Santos et al., 1987

18/ Iglesias, 1988
19/ Miranda et al., 1989

20/ Burton et al., 1990

21/ Zimback, 1992

22/ Phul \& Sharma, 1993

23/ Mansur et al., 1993

24/ Orf \& Helms, 1994

25/ Dashiell et al., 1994

26/ Montaño-Velasco, 1994

27/ Farias-Neto, 1995

28/ Santos et al., 1995a

NDF: número de dias para a floração; APF: altura da planta na floração; NDM: número de dias para a maturidade; APM: altura da planta na maturidade; AC: acamamento; VA: valor agronômico; PG: produtividade de grãos; OL: teor de óleo; PO: produtividade de óleo; e PROT: teor de proteina.

* Herdabilidade no sentido restrito 
Apêndice 2 Estimativas de correlações genotípicas e fenotípicas entre varios caracteres de soja encontrados na literatura.

\begin{tabular}{|c|c|c|c|c|c|c|c|c|c|}
\hline \multicolumn{2}{|c|}{$\begin{array}{c}\text { Associação } \\
\text { entre } \\
\text { caracteres }\end{array}$} & $\begin{array}{l}\text { Weber \& } \\
\text { Moorthy } \\
1952\end{array}$ & $\begin{array}{l}\text { Anand \& } \\
\text { Torrie } 1963\end{array}$ & $\begin{array}{l}\text { Kwon \& } \\
\text { Torrie } 1964\end{array}$ & $\begin{array}{c}\text { Monteverde } \\
1984\end{array}$ & $\underset{1992}{\text { Zimback }}$ & $\begin{array}{c}\text { Montano } \\
\text { Velasco } \\
1994\end{array}$ & $\begin{array}{c}\text { Farias Neto } \\
1995\end{array}$ & $\begin{array}{c}\text { Santos } \\
\text { et al 1995a }\end{array}$ \\
\hline \multicolumn{10}{|c|}{ PG com: } \\
\hline \multirow{2}{*}{ ndf } & $\mathbf{r}_{\mathbf{z}}$ & $-0,02 ; 0,40$ & 0,$26 ; 0,76$ & 0,$69 ; 0,87$ & & 0,90 & 0,91 & & 0,85 \\
\hline & $\mathbf{r}_{\mathbf{f}}$ & 0,$07 ; 0,14$ & 0,$11 ; 0,37$ & 0,$47 ; 0,68$ & & 0,92 & 0,89 & & 0,57 \\
\hline \multirow{2}{*}{\multicolumn{2}{|c|}{ apf }} & & & & & 0,88 & 0,88 & & 0,73 \\
\hline & & & & & & 0,87 & 0,86 & & 0,61 \\
\hline \multirow{2}{*}{\multicolumn{2}{|c|}{ ndm }} & 0,$41 ; 0,53$ & $0.01 ; 0,99$ & 0,$52 ; 0,95$ & 0,$34 ; 0,74$ & 0,87 & 0,84 & 0,46 & 0,86 \\
\hline & & 0,$22 ; 0,28$ & 0,$04 ; 0,48$ & 0,$37 ; 0,75$ & 0,$23 ; 0,38$ & 0,86 & 0,81 & 0,27 & 0,58 \\
\hline \multirow{2}{*}{\multicolumn{2}{|c|}{ apm }} & 0,$15 ; 0,46$ & 0,$43 ; 0,65$ & 0,$54 ; 0,82$ & 0,$64 ; 0,92$ & 0,79 & 0,76 & 0,74 & 0,40 \\
\hline & & 0,$21 ; 0,31$ & 0,$32 ; 0,44$ & 0,$44 ; 0,69$ & 0,$47 ; 0,59$ & 0,79 & 0,74 & 0,38 & 0,34 \\
\hline \multirow{2}{*}{\multicolumn{2}{|c|}{ prot. }} & & & $-0,58$ & 0,$33 ; 0,59$ & & & & \\
\hline & & & & $-0,42$ & $-0,26 ; 0,01$ & & & & \\
\hline \multirow{2}{*}{\multicolumn{2}{|c|}{ óleo }} & $-0,23 ; 0,68$ & & 0,07 & $-0,31 ; 0,26$ & $-0,07$ & $-0,31$ & 0,04 & \\
\hline & & $-0,10 ; 0,09$ & & 0,05 & $-0,15 ; 0,06$ & $-0,07$ & $-0,12$ & 0,01 & \\
\hline \multicolumn{10}{|c|}{ NDF com: } \\
\hline \multirow{2}{*}{\multicolumn{2}{|c|}{ apf }} & & & & & 0,96 & 0,98 & & 0,81 \\
\hline & & & & & & 0,95 & 0,97 & & 0,74 \\
\hline \multirow{2}{*}{\multicolumn{2}{|c|}{ ndm }} & 0,$54 ; 0,88$ & 0,$78 ; 0,88$ & 0,$67 ; 0,88$ & & 0,94 & 0,96 & & 0,75 \\
\hline & & 0,$51 ; 0,77$ & 0,$56 ; 0,83$ & 0,$62 ; 0,83$ & & 0,93 & 0,95 & & 0,73 \\
\hline \multirow{2}{*}{\multicolumn{2}{|c|}{ apm }} & 0,$38 ; 0,88$ & 0,$09 ; 0,62$ & 0,$21 ; 0,81$ & & 0,75 & 0,76 & & 0,42 \\
\hline & & 0,$17 ; 0,33$ & 0,$05 ; 0,56$ & 0,$19 ; 0,78$ & & 0,73 & 0,75 & & 0,39 \\
\hline \multirow{2}{*}{\multicolumn{2}{|c|}{ prot. }} & & & $-0,28$ & & & & & \\
\hline & & & & $-0,25$ & & & & & \\
\hline \multirow{2}{*}{\multicolumn{2}{|c|}{ óleo }} & $-0,47 ; 0,28$ & & $-0,13$ & & $-0,19$ & $-0,70$ & & \\
\hline & & $-0,36 ; 0,23$ & & $-0,10$ & & $-0,18$ & $-0,27$ & & \\
\hline \multicolumn{10}{|c|}{ APF com: } \\
\hline \multirow{2}{*}{\multicolumn{2}{|c|}{ ndm }} & & & & & 0,90 & 0,94 & & 0,51 \\
\hline & & & & & & 0,89 & 0,91 & & 0,44 \\
\hline \multirow{2}{*}{\multicolumn{2}{|c|}{ apm }} & & & & & 0,79 & 0,82 & & 0,43 \\
\hline & & & & & & 0,78 & 0,81 & & 0,44 \\
\hline \multirow{2}{*}{\multicolumn{2}{|c|}{ óleo }} & & & & & $-0,12$ & $-0,89$ & & \\
\hline & & & & & & $-0,11$ & $-0,30$ & & \\
\hline \multicolumn{10}{|c|}{ NDM com: } \\
\hline \multirow[t]{2}{*}{ apm } & & 0,$13 ; 0,46$ & 0,$08 ; 0,64$ & 0,33;0,77 & 0,$15 ; 0,44$ & 0,64 & 0,67 & 0,56 & 0,52 \\
\hline \multirow{3}{*}{\multicolumn{2}{|c|}{ prot. }} & 0,$32 ; 0,54$ & 0,$07 ; 0,58$ & 0,$29 ; 0,72$ & 0,$12 ; 0,32$ & 0,62 & 0,65 & 0,21 & 0,42 \\
\hline & & & & $-0,30$ & 0,$01 ; 0,17$ & & & & \\
\hline & & & & $-0,26$ & $-0,03 ;-0,16$ & & & & \\
\hline óleo & & $-0,45 ;-0,24$ & & $-0,14$ & $-0,23 ; 0,34$ & $-0,25$ & $-0,60$ & 0,05 & \\
\hline & & $-0,44 ; 0,20$ & & $-0,14$ & $-0,05 ; 0,02$ & $-0,24$ & $-0,25$ & $-0,06$ & \\
\hline APM & & & & & & & & & \\
\hline prot. & & & & $-0,14$ & 0,$38 ; 0,65$ & & & & \\
\hline & & & & $-0,13$ & 0,$13 ; 0,24$ & & & & \\
\hline óleo & & $-0,54 ; 0,29$ & & $-0,08$ & $-0,31 ;-0,45$ & $-0,05$ & $-0,58$ & $-0,18$ & \\
\hline & & $-0,25 ; 0,13$ & & $-0,07$ & $-0,23 ;-0,26$ & $-0,04$ & $-0,20$ & $-0,04$ & \\
\hline Prot. & & & & & & & & & \\
\hline óleo & & & & $-0,66$ & $-0,74$ & & & & \\
\hline & & & & $-0,54$ & $-0,61$ & & & & \\
\hline
\end{tabular}

$\mathbf{r}_{\mathbf{g}}$ : correlações genotípicas

r: correlaçōes fenotípicas

PG: produtividade de grãos; NDF: número de dias para a floração; APF: altura da planta na floração; NDM: número de dias para a maturidade; APM: altura da planta na maturidade; PROT: teor de proteina;e ÓLEO: teor de óleo. 
Apêndice 3 Genealogias de 40 cruzamentos em cadeia e testemunhas. Soja. Piracicaba, SP, 1996.

\begin{tabular}{|c|c|c|c|}
\hline \multicolumn{2}{|r|}{ CADEIA MISTA } & \multicolumn{2}{|r|}{ CADEIA ADAPTADA } \\
\hline CRUZ. & GENEALOGIA & CRUZ. & GENEALOGIA \\
\hline $1 \times 2$ & Andrews Púrpura x FT 81-2706 & $21 \times 22$ & Bienville x UFV- Araguaia \\
\hline $2 \times 3$ & FT $81-2706 \times$ PI 371.610 & $22 \times 23$ & UFV-Araguaia x Bossier-s \\
\hline $3 \times 4$ & PI 371.610 x Paraná-s & $23 \times 24$ & Bossier-s x UFV-2 \\
\hline $4 \times 5$ & Paraná-s x Kirby & $24 \times 25$ & UFV-2 x GO 81-8491 \\
\hline $5 \times 6$ & Kirby x FT-2 & $25 \times 26$ & GO 81-8491 x BR 80-15725-B-s \\
\hline $6 \times 7$ & FT-2 x N 82-2764-s & $26 \times 27$ & BR 80-15725-B-s x Planalto-s \\
\hline $7 \times 8$ & N 82-2764-s x SOC 81-127-s & $27 \times 28$ & Planalto-s x GO 81-11094 \\
\hline $8 \times 9$ & SOC 81-127-s x Wright & $28 \times 29$ & GO 81-11094 x BR-11 \\
\hline $9 \times 10$ & Wright x SOC 81-76 & $29 \times 30$ & BR-11 x FT-8 \\
\hline $10 \times 11$ & SOC $81-76 \times$ Foster & $30 \times 31$ & FT-8 x OC 79-7 \\
\hline $11 \times 12$ & Foster x FT 79-3408 & $31 \times 32$ & OC 79-7 x BR-9 \\
\hline $12 \times 13$ & FT 79-3408 x AX 5355-s & $32 \times 33$ & BR-9 x EMGOPA-301 \\
\hline $13 \times 14$ & AX 5355-s x Paranagoiana & $33 \times 34$ & EMGOPA-301 x IAC-9 \\
\hline $14 \times 15$ & Paranagoiana x Jackson 4028-s & $34 \times 35$ & IAC-9 x GO 79-1030 \\
\hline $15 \times 16$ & Jackson 4028-s x FT 81-2129 & $35 \times 36$ & GO 79-1030 x Cristalina-s \\
\hline $16 \times 17$ & FT 81-2129 x Cobb & $36 \times 37$ & Cristalina-s x IAC-6 \\
\hline $17 \times 18$ & Cobb $\times$ BR-8 & $37 \times 38$ & IAC-6 x UFV-4 \\
\hline $18 \times 19$ & BR-8 x PI 200521 & $38 \times 39$ & UFV-4 x BR 80-16309 \\
\hline $19 \times 20$ & PI 200521 x SOC $81-216$ & $39 \times 40$ & BR 80-16309 x UFV-1 \\
\hline $20 \times 1$ & SOC 81-216 x Andrews Púpura & $40 \times 21$ & UFV-1 x Bienville \\
\hline
\end{tabular}

TESTEMUNHAS

Bossier

IAC-12

UFV-4

IAC-Santa Maria 702 
Apêndice 4a Fotoperíodo, temperatura, umidade relativa e precipitação pluviométrica, no período de janeiro a junho de 1994, relativos à avaliação da geração $\mathrm{F}_{6: 3}$ de soja em Piracicaba, SP.

\begin{tabular}{||l|c|c|c|c|c|c||}
\hline \multirow{2}{*}{ Meses } & \multirow{2}{*}{$\begin{array}{c}\text { Fotoperíodo } \\
\text { (h) }\end{array}$} & \multicolumn{3}{|c|}{ Temperatura ( ${ }^{\circ} \mathrm{C}$ ) } & $\begin{array}{c}\text { Umidade } \\
\text { Relativa (\%) }\end{array}$ & $\begin{array}{c}\text { Precipitação } \\
\text { Pluvial (mm) }\end{array}$ \\
\cline { 3 - 7 } & Média & Máxima & Mínima & 83,7 & 134,8 \\
\hline Janeiro & 13,20 & 24,8 & 30,3 & 19,3 & 82,7 & 154,4 \\
\hline Fevereiro & 12,80 & 26,6 & 33,0 & 20,2 & 84,4 & 222,7 \\
\hline Março & 12,07 & 24,1 & 30,0 & 18,5 & 81,1 & 114,9 \\
\hline Abril & 11,38 & 22,8 & 29,0 & 16,6 & 81,8 & 45,2 \\
\hline Maio & 10,85 & 20,9 & 26,8 & 15,0 & 78,1 & 36,7 \\
\hline Junho & 10,60 & 17,6 & 24,8 & 10,3 & & \\
\hline
\end{tabular}

Fonte: Departamento de Física e Meteorologia - Escola Superior de Agricultura "Luiz de Queiroz"/ USP.

Apêndice 4b Fotoperíodo, temperatura, umidade relativa e precipitação pluviométrica, no período de novembro/94 a março/1995, relativos à avaliação da geração $\mathrm{F}_{7: 3}$ de soja em Piracicaba, SP.

\begin{tabular}{|c|c|c|c|c|c|c|}
\hline \multirow[b]{2}{*}{ Meses } & \multirow{2}{*}{$\begin{array}{l}\text { Fotoperíodo } \\
\text { (h) }\end{array}$} & \multicolumn{3}{|c|}{ Temperatura $\left({ }^{\circ} \mathrm{C}\right)$} & \multirow{2}{*}{$\begin{array}{c}\text { Umidade } \\
\text { Relativa (\%) }\end{array}$} & \multirow{2}{*}{$\begin{array}{l}\text { Precipitação } \\
\text { pluvial (mm) }\end{array}$} \\
\hline & & Média & Máxima & Mínima & & \\
\hline Outubro & 12,70 & 25,3 & 32,2 & 18,4 & 72,8 & 126,8 \\
\hline Novembro & 13,10 & 24,6 & 30,7 & 18,6 & 74,5 & 249,2 \\
\hline Dezembro & 13,46 & 25,8 & 32,0 & 20,0 & 79,6 & 260,8 \\
\hline Janeiro & 13,20 & 26,2 & 32,0 & 20,1 & 83,9 & 197,3 \\
\hline Fevereiro & 12,80 & 25,0 & 29,9 & 20,1 & 88,2 & 415,6 \\
\hline Março & 12,07 & 24,5 & 30,4 & 18,5 & 83,5 & 194,6 \\
\hline
\end{tabular}

Fonte: Departamento de Física e Meteorologia - Escola Superior de Agricultura "Luiz de Queiroz"/ USP. 
Apêndice 5a Critérios utilizados para a interpretação de análises de solos para o Estado de São Paulo.

\begin{tabular}{|c|c|c|c|c|c|c|c|c|}
\hline \multirow[t]{2}{*}{ Acidez } & \multirow{2}{*}{$\begin{array}{c}\mathrm{pH} \\
\mathrm{CaCl}_{2}\end{array}$} & \multirow[b]{2}{*}{ Níveis } & \multirow{2}{*}{$\begin{array}{l}\text { M.O. } \\
(\%)\end{array}$} & \multirow{2}{*}{$\begin{array}{c}P \\
\left(\mu \mathrm{g} / \mathrm{cm}^{3}\right)\end{array}$} & \multicolumn{3}{|c|}{ Meq/100g } & \multirow{2}{*}{$\begin{array}{c}\mathrm{V} \\
(\%)\end{array}$} \\
\hline & & & & & $\mathbf{K}$ & $\mathrm{Ca}$ & Mg & \\
\hline Muito baixa & $>6,0$ & Muito baixo & - & 6,0 & 0,07 & - & - & $\leq 25$ \\
\hline Baixa & $5,6-6,0$ & Baixo & 1,5 & $7,08-15,0$ & $0,08-0,15$ & 0,4 & 0,4 & $26-50$ \\
\hline Média & $5,1-5,5$ & Médio & $1,5-2,5$ & $0,15-40,0$ & $0,16-30,0$ & $0,5-0,8$ & $0,5-0,8$ & $51-70$ \\
\hline Alta & $4,4-5,0$ & Alto & $>2,5$ & $>80,0$ & $>80,0$ & - & - & $71-90$ \\
\hline Muito alta & $<4,3$ & Muito alto & - & & - & - & - & $>90$ \\
\hline
\end{tabular}

Fonte: Malavolta et al. (1989).

Apêndice 5b Análises químicas do solo nas áreas de pesquisa com soja, nos locais Areão e Anhembi, Piracicaba - SP.

\begin{tabular}{|c|c|c|c|c|c|c|c|}
\hline \multirow{2}{*}{ Local } & \multirow{2}{*}{$\begin{array}{c}\mathrm{pH} \\
\mathrm{CaCl}_{2}\end{array}$} & \multirow{2}{*}{$\begin{array}{r}\text { M.O. } \\
(\%)\end{array}$} & \multirow{2}{*}{$\begin{array}{c}P \\
\left(\mu \mathrm{g} / \mathrm{cm}^{3}\right)\end{array}$} & \multicolumn{3}{|c|}{ Meq/100g } & \multirow{2}{*}{$\begin{array}{c}V \\
(\%)\end{array}$} \\
\hline & & & & $\mathbf{K}$ & $\mathbf{C a}$ & Mg & \\
\hline Areão" & 4,3 & 1,6 & $10,0-15,0$ & 0,25 & 3,6 & 1,3 & 50 \\
\hline Anhembi $^{2}$ & 6,5 & 1,6 & 55,0 & 0,23 & 2,9 & 2,3 & 90 \\
\hline
\end{tabular}

Fonte: 'Departamento de Ciência do Solo-ESALQ/USP - 26/07/96.

${ }^{2}$ Departamento de Química-ESALQ/USP - 21/06/96. 
Apêndice 6 Esquema de entrada de dados e sequência de comandos utilizados no programa MAPGEN para análise estatística em blocos aumentados.

\section{a) Esquema e estrutura dos dados}

Para se utilizar o programa, o primeiro passo é possuir um arquivo criado no editor (D123) do próprio programa ou um arquivo texto (ASC II) que deve ser importado para o formato do editor (D123) antes de ser usado.

Após o usuário já ter seu arquivo (D123), o próximo passo é escolher a opção (1) do menu principal para efetuar a análise desejada.

Em seguida, o usuário deverá indicar qual arquivo e quais variáveis vão ser utilizadas nas análises, além das variáveis (colunas) dos tratamentos regulares, das testemunhas e dos blocos, e também o número de cada um destes parâmetros ( $n^{0}$ blocos, $\mathrm{n}^{0}$ testemunhas e $\mathrm{n}^{0}$ de tratamentos regulares).

$\mathrm{O}$ máximo de parcelas é 6.500 ou seja, $\mathrm{b} * \mathrm{t}+\mathrm{v} \leq 6.500$.

$O$ arquivo D123 (do editor) tem que ter a seguinte estrutura: uma coluna para tratamentos regulares, que é numerada de $1 \mathrm{a} \mathrm{v}$; outra coluna para as testemunhas, que é numerada de 1 a t; e outra coluna para os blocos, que é numerada de 1 a b; se um determinado tratamento ocorre no bloco $\mathrm{j}$, então este deve ter $\mathrm{o}$ valor $\mathrm{J}$.

A seguir, um exemplo de estrutura dos dados com cinco tratamentos regulares, duas testemunhas e dois blocos:

$\begin{array}{ccccc}\text { Tratamentos Regulares } & \text { Testemunhas } & \text { Blocos } & \text { Produção } & \text { Etc. } \\ 1 & 0 & 1 & 2.0 & : \\ 2 & 0 & 1 & 3.0 & : \\ 3 & 0 & 1 & 4.0 & : \\ 4 & 0 & 2 & 3.0 & : \\ 5 & 0 & 2 & 6.0 & : \\ 0 & 1 & 1 & 2.0 & : \\ 0 & 1 & 2 & 3.0 & : \\ 0 & 2 & 1 & 4.0 & \text {. }\end{array}$

Observar que não é necessário ter blocos do mesmo tamanho, mas é necessário ter as testemunhas em todos os blocos. 
b - Sequência de Comandos

- Selecionar a opção 3 (editar) do menu principal

- Selecionar Importar

Drive: nome do arquivo ASC II

B: EXEMPLO.PRN

Confirma o nome: $\mathrm{Y} / \mathrm{N}$

Drive: nome do arquivo D123

B: EXEMPLO (o programa cria a extensão PTA automaticamente)

Confirma o nome: $\mathrm{Y} / \mathrm{N}$

- Selecionar arquivo

- Selecionar Ativar Velho

Drive: nome do arquivo

B: EXEMPLO.PTA (desta forma o arquivo já pode ser trabalhado)

- Selecionar QUIT

- Quer abandonar D123 Y/N ?

- Selecionar a opção (1) no menu principal número (coluna) da variável: tratamento regular número (coluna) da variável: testemunhas/tratamentos comuns número (coluna) da variável: bloco número total de tratamentos regulares: $\mathbf{v}$ número de tratamentos comuns (testemunhas): $t$ número de blocos: $\mathrm{b}$

<Drive > : nome do arquivo B: EXEMPLO.PTA Número (coluna) da variável analisar Digite "ESC" para encerrar. 